$\mathrm{DOE} / \mathrm{CS} / 50017-1$

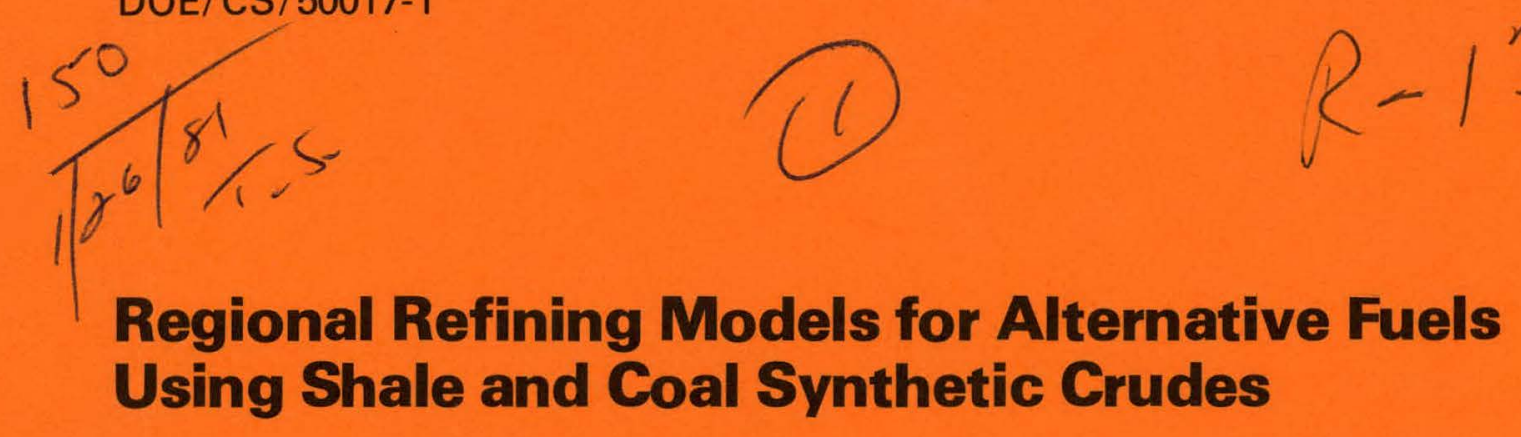

Dr. 2227 Using Shale and Coal Synthetic Crudes

Annual Report for period 20 March 1979 to 19 March 1980 for the Project Identification and Evaluation of Optimized Alternative Fuels

\title{
Alternative Fuels Utilization Program
}

November, 1980

Prepared For

\section{U.S. Department of Energy}

Assistant Secretary for Conservation and Solar Energy

Office of Transportation Programs

Under Contract No. AC01-79CS-50017 


\section{DISCLAIMER}

This report was prepared as an account of work sponsored by an agency of the United States Government. Neither the United States Government nor any agency Thereof, nor any of their employees, makes any warranty, express or implied, or assumes any legal liability or responsibility for the accuracy, completeness, or usefulness of any information, apparatus, product, or process disclosed, or represents that its use would not infringe privately owned rights. Reference herein to any specific commercial product, process, or service by trade name, trademark, manufacturer, or otherwise does not necessarily constitute or imply its endorsement, recommendation, or favoring by the United States Government or any agency thereof. The views and opinions of authors expressed herein do not necessarily state or reflect those of the United States Government or any agency thereof. 


\section{DISCLAIMER}

Portions of this document may be illegible in electronic image products. Images are produced from the best available original document. 


\section{NOTICE}

This report was prepared as an account of work sponsored by the United States Government. Neither the United States nor the United States Department of Energy, nor any of their employees, makes any warranty, express or implied, or assumes any legal liability or responsibility for the accuracy, completeness, or usefulness of any information, apparatus, product, or process disclosed, or represents that its use would not infringe privately owned rights. Reference herein to any specific commercial product, process, or service by trade name, mark, manufacturer, or otherwise, does not necessarily constitute or imply its endorsement, recommendation, or favoring by the United States Government or any agency thereof. The views and opinions of authors expressed herein do not necessarily state or reflect those of the United States Gnvernment or any agency theitul.

Avallable from:

National Technical Information Service (NTIS)

U.S. Department of Commerce

5285 Port Royal Road

Springfield, Virginia 22161

Price: Printed Copy: $\$ 14.00$

Microfiche: $\$ 4.00$ 


\section{MASTER}

$\mathrm{DOE} / \mathrm{CS} / 50017-1$

Distributión Category UC-96

\section{Regional Refining Models for Alternative Fuels Using Shale and Coal Synthetic Crudes}

Annual Report for period 20 March 1979 to 19 March 1980 for the Project Identification and Evaluation of Optimized Alternative Fuels

\section{Alternative Fuels Utilization Program}

November, 1980

Prepared By

Norman R. Sefer

John A. Russell

Southwest Research Institute

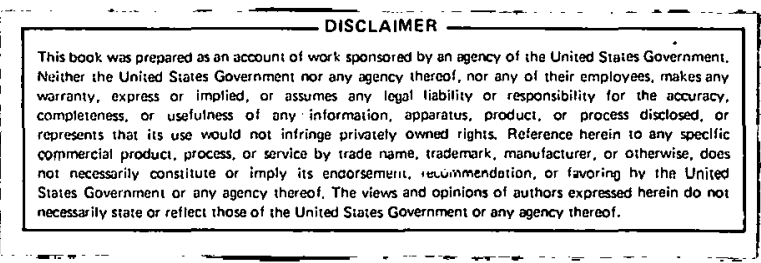

Mobile Energy Division

San Antonio, Texas 78284

Under Contract No. AC01-79C550017

Prepared For

U.S. Department of Energy

Assistant Secretary for Conservation and Solar Energy

Office of Transportation Programs

Washington D.C. 20585 
THIS PAGE

\section{WAS INTENTIONALLY LEFT BLANK}


FOREWORD

The work reported hereln was performed under Department of Energy Contract No. DE-AC01-79CS-50017. Southwest Research Institute, San Antonio, Texas, was the prime contractor. Subcontractors were Bonner \& Moore Associates, Inc., Houston, Texas and The Standard 011 Company of Ohio, Technology and Planning Department, Cleveland, Ohio. The contract was administered by the office of Procurement Operations, Washington, D.C. Technical Project Manager was Dr. Ralph D. Fleming, Alternative Fuels Utilization Branch at DOE Headquarters. 
The initial phase has been completed in the project to evaluate alternative fuels for highway transportation from synthetic crudes. Three refinery models were developed for Rocky Mountain; Mid-Continent and Great Lakes regions to make future product volumes and qualities forecast for 1995 .

Projected quantities of shale oll and coal ofl syncrudes were introduced 'into the raw materials slate. Product slate was' then varied from conventional products to evaluate maximum diesel fuel and broadcut fuel in all regions. Gasoline supplement options were evaluated in one region for 10 percent. each of methanol, ethanol, MTBE or synthetic naphtha in the blends along with syncrude components.

Compositions and qualities of the fuels were determined for the variation in constraints and conditions established for the study, Efferts on raw materials, energy consuiuption and investment costs were reported. Results provide the basis to formulate fuels for laboratory and englue evaluation in future phases of the project. 
Meeting the objectives.in the first year of the project required the efforts of many participants. The co-authors, Allen Mesch, Joe Dickson and Frank Frederick of Bonner \& Moore contributed to the planning and design of the case studies as well as the execution and documentation of computer runs. Robert Rightmire and Warren Wotring of SOHIO helped get the project off to a good start and contributed advice and data as needed throughout.

Thanks are extended to many SwRI staff members: To John Russell who originated the project, provided guidance to keep it on track, and authored sections of the report. To Brent Bailey for data handling and computer graphics. To Jim Pryor for editorial advice. To Myrtie Santee, Gladys Tate and Judy Brandle who persevered through typing multiple drafts to produce an eminently readable report.

The use of facilities and technical support from the U.S. Army Fuels and Lubricants Research Laboratory at Southwest Research Institute is appreciated. Analytical work was done with the concurrence of the U.S. Army Mobility Equipment Research and Development Command (MERADCOM).

Norman R. Sef er Principal Investigator Southwest Research Institute 


\section{THIS PAGE \\ WAS INTENTIONALLY \\ LEFT BLANK}




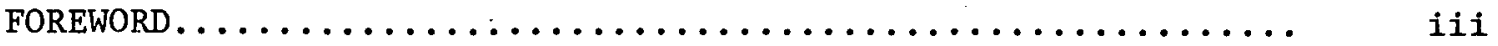

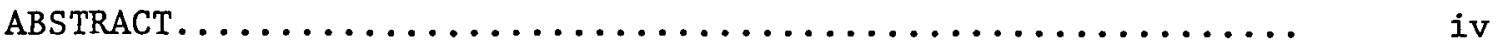

ACKNOWLEDGMENTS............................. v

LIST OF ILLUSTRATIONS....................... ix

LIST OF TABLES............................ $x i$

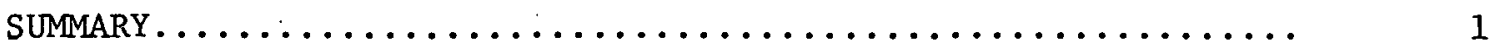

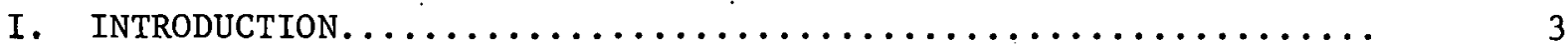

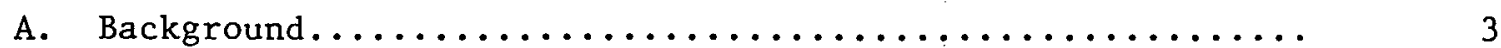

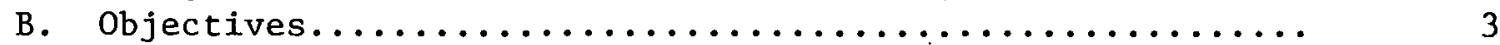

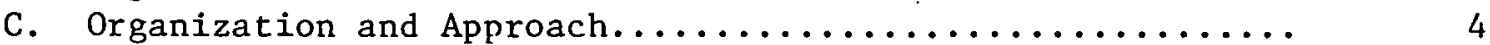

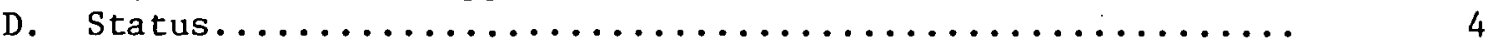

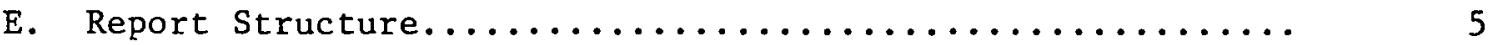

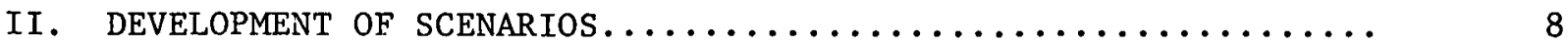

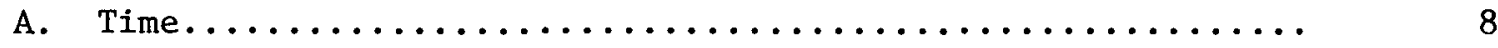

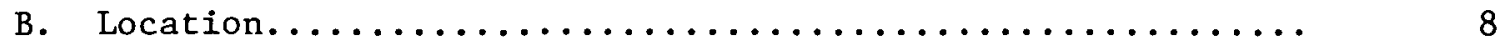

C. Syncrude Availability....................... 8

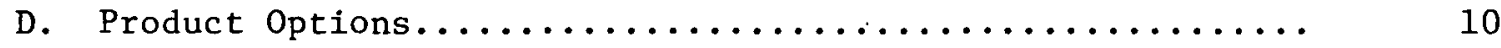

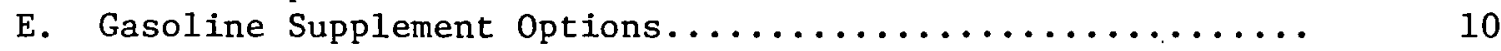

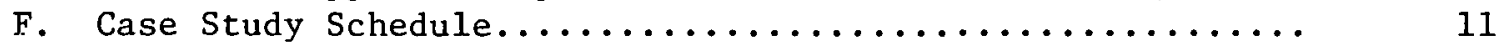

G. Projection of New Engine Penetration............... 11

III. FUELS PRODUCTION MODEL........................... 17

A. Refinery and Petrochemical Modeling Systems (RPMS)......

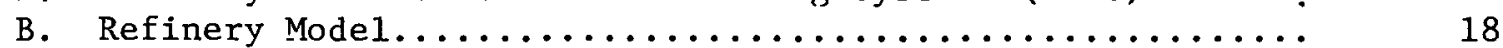

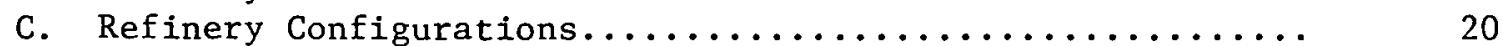

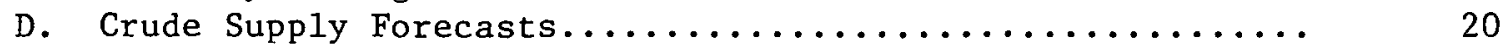

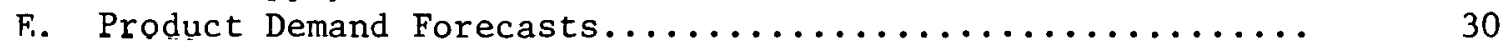

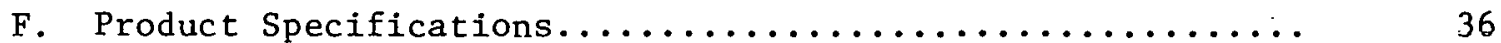

G. Additional Modeling Considerations.................. 39

H. Model Generation-Regional Base Cases for 1995........... 40

I. Volumes of Diesel and.Broadcut Fuels................ 41

IV. SYNCRUDE PROCESSING........................... 48

A. Synrrude Process Selection Criteria............... 48

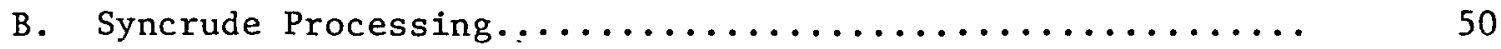

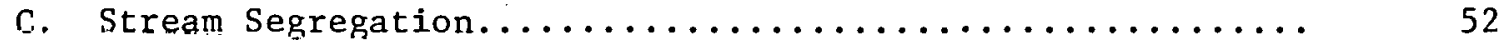

D. Syncrude Assay Data........................... 53

V. GASOLINE SUPPLEMENTS.......................... 63 


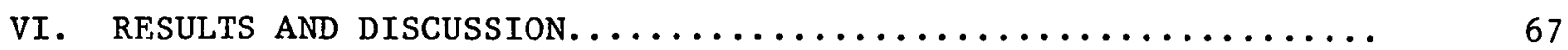

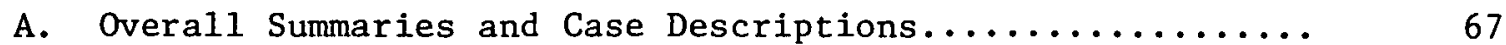

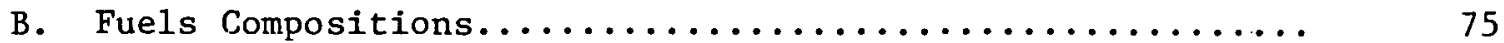

C. Raw Materials Effects........................ 101

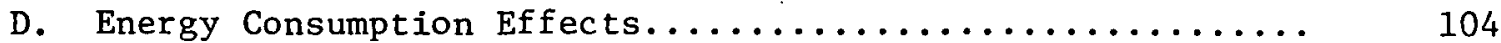

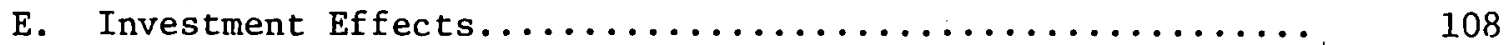

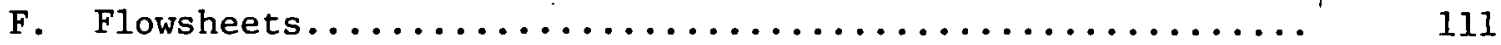

G. Product Quality.......................... 120

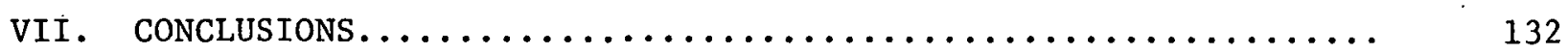

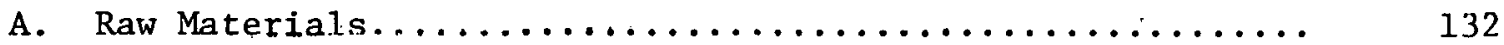

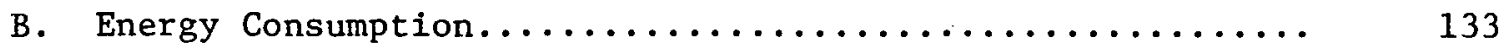

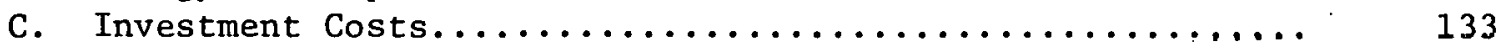

n. Compositions and Pruduct Quality................... 134

VIIT. FUTURE WORK............................... 135

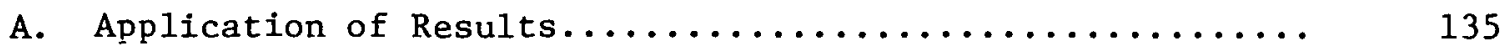

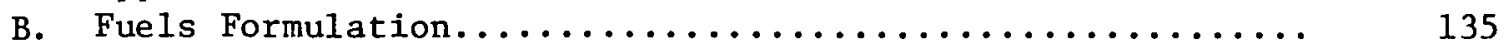

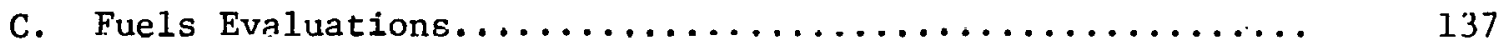

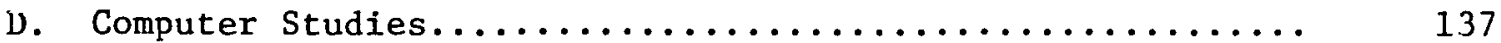

E. Recommendations for Other Research............... 138

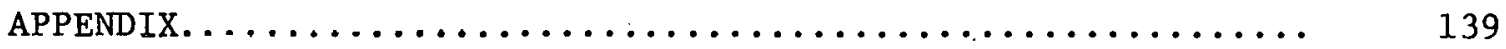

LIST OF ACRONYMS AND ABBREVIATIONS................. 141

DEFINITIONS, ................................ 143 
LIST OF ILLUSTRATIONS

$\underline{\text { Figure }}$

$\underline{\text { Page }}$

1.1 Identification, Formulation, and Evaluation of Alternative Highway Transportation Fuels..................... 6

2.1 Regions for Composite Fuels Production Models............ 9

2.2 Percent Vehicle Miles - New Cars.................... 13

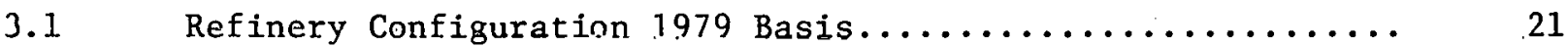

$3.2 \quad$ P.A.D. Districts......................... 23

3.3 Rocky Mountain Crude Distillation..................... 29

$3.4 \quad$ Flowchart for Energy Forecast System................ 32

$4.1 \quad$ Processing Options - Shale Oils................... 54

4.2 Processing Options - Coal 0ils................... 54

4.3 Synthetic Crude Distillation Hydrotreated Shale and Coal $0 i 1 \quad 57$

4.4 Synthetic Crude Distillation Coal Oils From Illinois Coal... 58

4.5 Synthetic Crude Distillation - Coal Oils From Wyoming Coal.. 59

Shale Oil Cases - Rocky Mountain Region

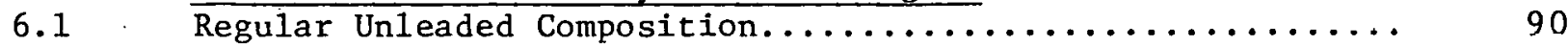

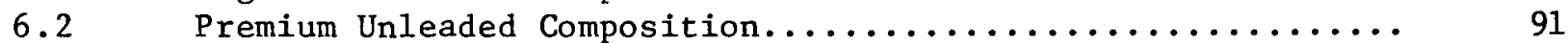

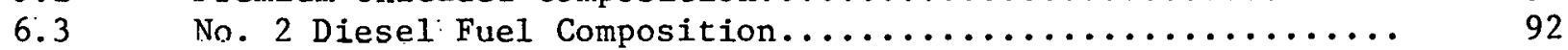

Coal Oil Cases - Rocky Mountain Region

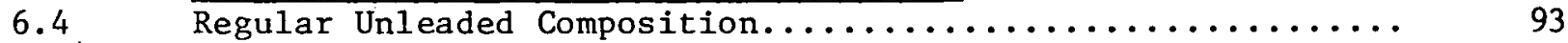

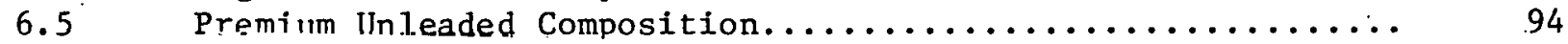

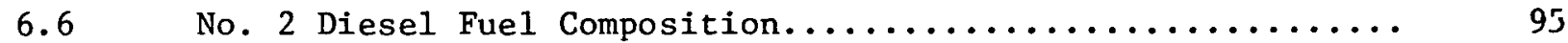

Shale and Coa1 Oil Cases - Mid-Continent and Great Lakes Region

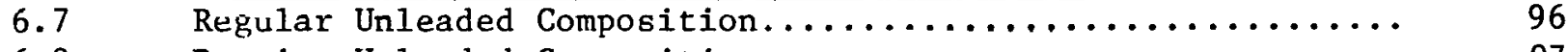

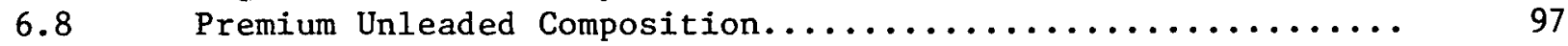

6.9 No. 2 Diesel Fuel Composition.................... 98

Broadcut Fuel Compositions

$6.10 \quad$ Shale and Cnal Oil Cases - All Regions................. 99 
Rocky Mountain Region

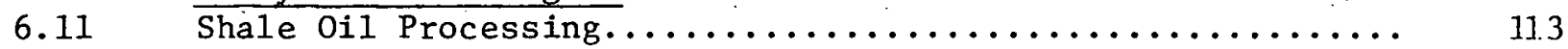

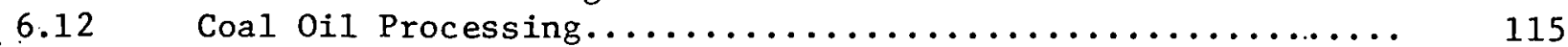

Mid-Continent and Great Lakes Region

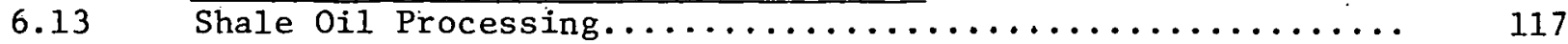

$6.14 \quad$ Coal $0 i 1$ Processing.................................. 119

6.15 Broadcut Fuel Distillations - Rocky Mountain Region....... 129

6.16 Broadcut Fuel Distillations - Mid-Continent Region........ 130

6.17 Broadcut Fuel Dislillalluns - Great Lakes Region........ 131 
2.1 Project Case study Schedule......................

3.3 Refinery Capacity, MBPSD....................... 27

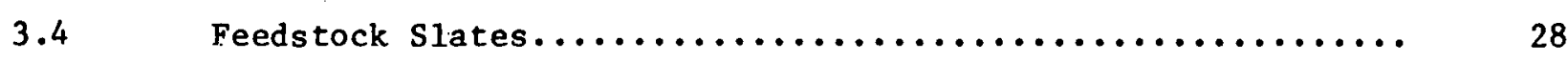

3.5 Regional Crude Feedstocks (Base Case Compositions)........ 31

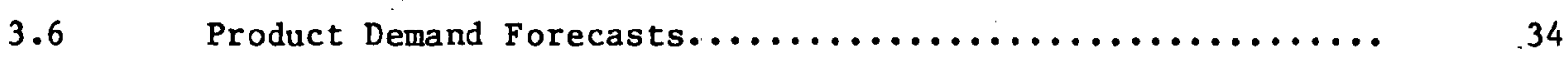

$3.7 \quad$ Product Demand on Regional Refineries................. 35

3.8 Transportation Fuel Product Specifications.............. 37

$3.9 \quad$ Broadcut Fuel Specifications...................... 38

3.10 Regional Base Cases for 1995, Overall Summary.......... 42

3.11 Regional Base Cases for 1995, Processing Summary......... 43

$3.12 \quad$ Regional Base Cases, Product Compositions............... 44

3.13 Product Volumes for Maximum Diesel and Broadcut Fuels...... 46

$4.1 \quad$ Syncrude Conversion Processes..................... 49

$4.2 \quad$ Syncrude Assay Data.......................... 56

$5.1 \quad$ Blending Values for special Gasoline Components.......... 65

Raw Materials and Products

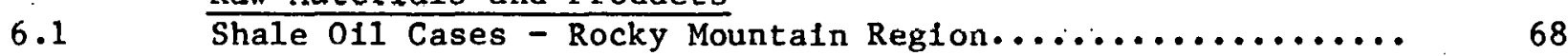

$6.2 \quad$ Coal 011 Cases - Rocky Mountain Region................... 69

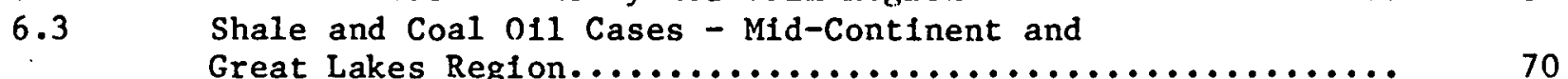

Utilities and New Facilities

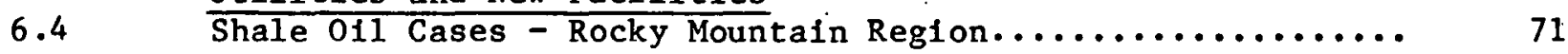

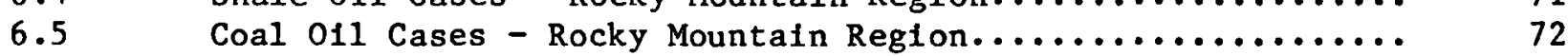

6.6 Shale and Coal 0il Cases - Mid-Continent and

Great Lakes Region............................. 73 
Table

$\underline{\text { Page }}$

6.7 Gasoline Pool Components..................... 75

6.8 Diesel Fuel Components....................... 76

6.9 RPMS Stream Allocation....................... 77

Shale Oil Cases - Rocky Mountain Region

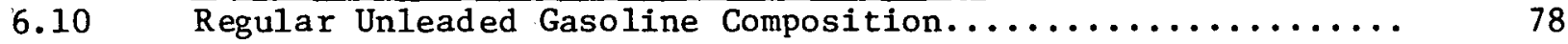

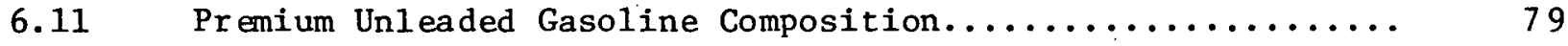

6.12 No. 2 Diesel Fuel Composition..................... 80

Coal Oil Cases - Rocky Mountain Region

$6.13 \quad$ Regular Unleaded Gasoline Composition................. 81

6.14 Premium Unleaded Gasoline Composition.................. 82

6.15 No. 2 Diesel Fuel Composition..................... 83

Shale and Coal Oil Cases - Mid-Continent and Great Lakes Region

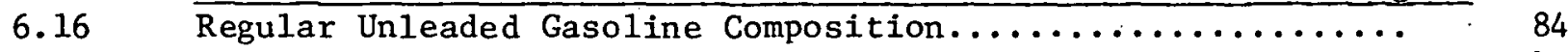

6.17 Premium Unleaded Gasoline Composition................ 85

6.18 No. 2 Diesel Fuel Composition..................... 86

$6.19 \quad$ Shale and Coal Oil Cases - Al 1 Regions................ 87

Ranges in Fuel Compositions

$6.20 \quad$ Rocky Mountain Region.......................... 88

Occurrence of Synthetic Components in Transportation Fuels

$6.21 \quad$ Roc ky Mountain Region......................... 100

Raw Materia1s Effects

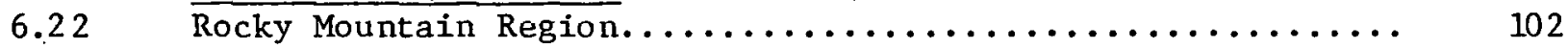

6.23 Mid-Continent and Great Lakes Regions................ 103

Energy Consumption Effects

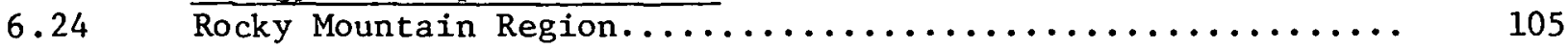

6.25 Mid-Continent and Great Lakes Regions................. 106

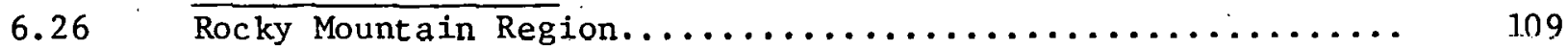

$6: 27$ Mid-Continent and Great Lakes Regions............... 110

6.28 Shale Oil Processing - Rocky Mountain Region............ 112 


\section{LIST OF TABLES (CONT'D)}

Table

Page

6.29 Coal 0il Processing - Rocky Mountain Region............

6.30 Shale 0il Processing - Mid-Continent and Great Lakes Region.

6.31 Coal Oil Processing - Mid-Continent and Great Lakes Region..

6.32 Shale Oil Cases - Rocky Mountain Region................

Product Qualities - Diesel and Broadcut Fuels

6.33 Shale Oil Cases - Rocky Mountain Region................

Product Qualities - Gasolines

6.34 Coa1 0i1 Cases - Rocky Mountain Region.................

Product Qualities - Diesel and Broadcut Fuels

6.35 Coa1 0il Cases - Rocky Mountain Region.................

124

Product Qualities - Gasolines

6.36 Shale and Coal Oil Cases - Mid-Continent Region...........

125

Product Qualities - Diesel and Broadcut Fuels

6.37 Shale and Coal 0il Cases - Mid-Continent Region...........

Product Qualities - Gasolines

6.38 Shale and Coal Oil Cases - Grèat Lakes Region.............

Product Qualities - Diese1 and Broadcut Fuels

6.39 Shale and Coal Oil Cases - Great Lakes Region 
THIS PAGE

\section{WAS INTENTIONALLY \\ LEFT BLANK}


Southwest Research Institute has completed the initial phase of the project to identify and evaluate alternative fuels for future highway transportation. Bonner \& Moore Associates provided a substantial portion of the synfuels optimization phase in using their Refinery and Petrochemical Modeling System (RPMS) to construct regional refinery models for a series of computer case study evaluations.

\section{Description}

The studies show how shale oil and coal oil may be used in a given processing scheme along with petroleum crudes to make specification products. Volumes of $300,000 \mathrm{~B} / \mathrm{D}$ shale oil and $200,000 \mathrm{~B} / \mathrm{D}$ coal oil were forecast to be available in 1995. Refineries in the Rocky Mountain, Mid-Continent or Great Lakes regions are expected to receive these syncrudes because of their location near production or transportation systems.

Forecasts of 1995 crude supply and product demand reflect regional differences in raw materials, product slate and product specifications. Composite refinery models were constructed using known 1979 configurations; facilities additions needed to make 1995 products were defined by the model in the base case for each region.

Because crude processing capacity is different in the three regions, inclusion of the projected volume of syncrudes in the crude slate resulted in different proportions in each region (conventional product cases shown):

$\%$ of Total Raw Materials

\begin{tabular}{cc}
\hline Shale Oil & Coal Oil \\
$300,000 \mathrm{~B} / \mathrm{D}$ & $200,000 \mathrm{~B} / \mathrm{D}$ \\
\hline
\end{tabular}

Rocky Mountains Mid-Continent Great Lakes
34.1

17.3

9.4
23.4

11.5

6.2

Shale oil and coal were processed separately in Rocky Mountain cases; they were charged simultaneously in the other regions but fractions were segregated for independent identity through processing and blending. The processing scheme applied hydrogenation pretreatment to both shale oils and one of three coal oils before distillation. Fractions from distillation were then further hydrotreated except for light naphtha and the residual streams.

Computer runs optimized many factors within the refinery, including a balance of cost effects. For example, the prescribed products were made with minimum raw materials, thereby controlling the major refinery cost. New facilities were provided only as needed since their investment cost (annualized) and operating costs are included in the total costs. Catalytic reforming octane level was balanced against yield loss. Certain feedstocks could bypass some operations if not needed for quality improvements. Finally, all components were blended in the best combinations to meet product specifications. 
Product options were evaluated in all three regions to study the effect of varying product types, including:

- Conventional products, 1995 forecast demand.

- Maximum diesel fue1, replacing 30 percent of gasoline.

- Broadcut fuel, replacing 40 percent of gasoline.

Broadcut fuel is a wide boiling range product, blended with components of both gasoline and diesel fuel, for use in advanced or modified engines which could be available in 1995. It is an example of fuels which require less processing than current motor fuels.

Gasoline supplements were evaluated in conjunction with shale and coal oils in the Rocky Mountain cases. Concentration of 10 volume percent of the following was used:

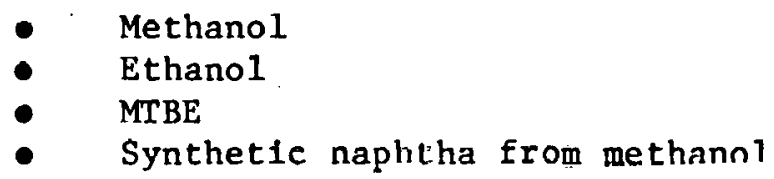

\section{Conclusions}

The refinery models demonstrated the changes in operation and products when shale and coal oil are included in the crude slate. Compositions determined for highway transportation fuels will be used to prepare test fuels for evaluation in the next phase of the projert.

Each barrel of shale or coal ofl replaced 0.95 or 1.03 barrels of petroleum new material, respectively. Investment cost and energy consumption inereased for buth syncrudes, but more so for shale ofl because it received more processing. Heavy fractions of coal oil went directly to No. 6 fuel oil because of properties less desirable in downstream processing.

Increasing diesel fuel production to the near-maximum level saved raw materials, partly by reducing product quantity because of better fuel economy for diesel. Other savings resulted from lower processing energy, except in one case where it increased because total distillate production was excessive.

Broadcut fuel production also saved raw materials. Product quantity savings were less than diesel fuel because fuel economy is between gasoline and diesel fuel. However, processing savings are larger than diesel fuel so the net effect on raw materials is simflar for either product option.

Broadcut fuel supply could be expanded while diesel fuel was near its limit in the maximum diesel cases. Broadcut fuel offers substantial savings in investment costs with syncrudes or with petroleum. Early development of engines to use broadcut fuel (or any fuel requiring less processing) is desirable to avold bullding facilities to make conventional fuels.

Methanol, ethano1, MTBE and synthetic naphtha all saved varying amounts of raw materials and energy consumption, although raw materials and energy used to make these supplements were not included. 


\section{INTRODUCTION}

\section{A. Background}

Early in 1976, Southwest Research Institute completed a survey study $(1)^{*}$ which provided an assessment of the impact of coal and ofl shale derived crudes upon the composition of gasoline. The interplay between petroleum, coal, and shale resources involved in optimum utilization of U.S. fossil resources was recognized and emphasized by all Federal and private organizations contacted. In that same year, a much more comprehensive study (2) was initiated to:

a. serve as a reference text for candidate conversion processes to derive liquid hydrocarbon and methanol fuels from coal or oll shale, and,

b. develop a methodology for projecting the compositions of these fuels in order to provide a means for estimation of energy consumption, environmental effects, and economic factors.

In April 1978, The Department of Energy (DOE) published the Alternative Fuels Utilization Program (AFUP) Planning Document (3) wherein the basic AFUP goal was identified, "to foster the use of alternative fuels by lowering the uncertainty costs associated with their use in highway vehicle systems." Uncertainty costs were taken to include direct dollar costs, social costs, and information costs. "Consequently, a lowering of these items would most certainly require identification of optimum resource utilization, :ninimum pretreatment and refinery energy expenditure, and maximum fuel economy. With these criteria, together with identified linear programming methodology (2) and an increasing knowledge of the compositional aspects of coal- and shale-derived liquids, this present study was formulated to establish a viable systems engineering approach which can be continuously updated as new laboratory and refining data are acquired.

In October 1978 (immediately prior to the initiation of this contract), a conference (4) on "Composition of Transportation Synfuels: R\&D Needs, Strategies and Actions" served to define further the areas where data could be applied to an optimization study. In parallel with this activity, DOE-AFUP had been devising a detalled Project Planning. Document (5) and an Alcohol Fuels Program Plan (6) which identified AFUP focus and scope together with a project activity policy emphasizing a broad-to-narrow approach. This present study was devised and timed to be compatible with these AFUP policies and goals.

\section{B. Objectives.}

This report describes work accomplished in the first year of a 3year, 4-task program intended to:

- Define chemical compositions and physical properties of alternative fuels derived from petroleum, coal, and shale oils.

* Underlined numbers in parentheses designate references at the end of each section. 
- Formulate, blend, and produce R\&D-scale quantities of prototype synthetic fuels.

- Identify problems associated with the use of these alternative fuels in conventional and advanced engine.

- Characterize promising fuel/engine combinations for minimum energy consumption in highway vehicles systems.

C. Organization and Approach

The four principal project activities (Tasks) into which work has been categorized are:

Task 1: Synfuels Optimization-application of linear programing tcchniques In a variety of scenarios to define chemical and physical characteristics of alternative transportation fuel optimized for minimum costs to satisfy produet leilduls.

Task 2: Synfuels Formulation for Experimental Evaluation-formulation and preparation of experimental batches of prototype synthetic fuels for use in bench test and internal combustion engine evaluations. These fuel formulations will have heen based upon but not limited to results developed in Task 1.

Task 3: Synfuels Formulation for Other Researchers-formulation, blending, and distribution of R\&D-scale quantities of prototype synfuels as defined in Task 2 for use in laboratories other than SwRI who have programs and/or facilities in which testing of these synfuels will provide data relevant to the DOE Alternative Fuels Uellization Program.

Task 4: Synfuels Performance Evaluation-bench test and engine evaluations using SwRI facilities to screen and ovaluate prototype synfuels to provide feedback information to the database established in Task 1 for further modification and refinement of linear programming modeling criteria.

\section{Status}

This first year's activities reported herein have entailed work solely on Task 1: Synfuels Optimization. Central to this effort has been the application of the Refinery and Petrochemical Modeling Systems (RPMS) developed by Bonner \& Moore Assnciatec, Houston, Texas, who have served as principal subcontractor. Proper utilization of RPMS for thle projective study required the expansion of an existing database on syncrude compositions and properties to include those from the most current known candidate processes for both coal- and shale-derived crudes. After this expansion, it was necessary to install quantitative data for syncrude hydrotreating pretreatment for sulfur and nitrogen removal as needed for these crudes to be processes by conventional refineries.

Changes were made from the preceding study (2), where quantity of coal- or shale-derived crude to a single refinery configuration was modeled 
as a timewise step function with increasing ratio of syncrude-to-petroleum crude in 5-year increments from 1985-2000. Modeling for this present study differs from the earlier one in that three separate regions (Rocky Mountain, Mid-Continent, and Great Lakes) have been established with a composite refinery configuration for each region extrapolated to the year 1995. Product slates have been forecast starting with gasoline-dominant. Then diesel-penetration and wide bolling range fuel-penetration variations are presumed. The concept of a wide bolling range fuel has been defined more precisely. As a corollary activity, RPMS modeling included an alcohol/ether fuel blending option so that selected blending components could be incorporated as octane improvers and finished gasoline supplements.

The main intent is to generate a comprehensive collection of formulations of such fuels which would then provide the basis for blending and laboratory and engine tests. The 4-task organization of this present program, together with the modular activities just described, is shown schematically in Figure 1.1 .

Future work will emphasize the physical aspects of this program including actual formulation and blending (Tasks 2 and 3 ), experimental evaluation (Task 4), plus the initial stages of a repository function in which SwRI will be a technical clearing house for AFUP-related synfuels data exchange and storage. In this last activity (emphasizing Task 3), R\&D-scale quantities of avallable prototype synfuels will commence to be furnished to other laboratories as described above with the understanding that data derived from these materials will be furnished to DOE, or to SwRI as their designated representative, for summarization and correlation.

\section{E. Report Structure}

The summary of the report is found in the section just preceding this Introduction. Following the Introduction are seven other sections which proceed from the general outline to more specific descriptions of the project work. The sections also approximate the chronological sequence of project activities from planning through execution to evaluation of results and future plans as indicated in the following paragraphs:

- Section II, Development of Scenarios, establishes the general plan for case studies considering major factors of time, location and syncrude quantities. The variations in product demand and gasoline supplement options provide the basis for a schedule of twenty-six cases to run.

- Section III, Fuels Production Mode1, describes the modeling system and development of three regional models and product forecasts for 1995. Details of modeling are discussed along with computer results for three regional base cases.

- Section IV, Syncrude Processing, defines the selection of shale olls and coal oils along with their processing scheme and key data for use in the models.

- Section V, Gasoline Supplements, discusses the four components to be used in gasoline and their incorporation into the models. 


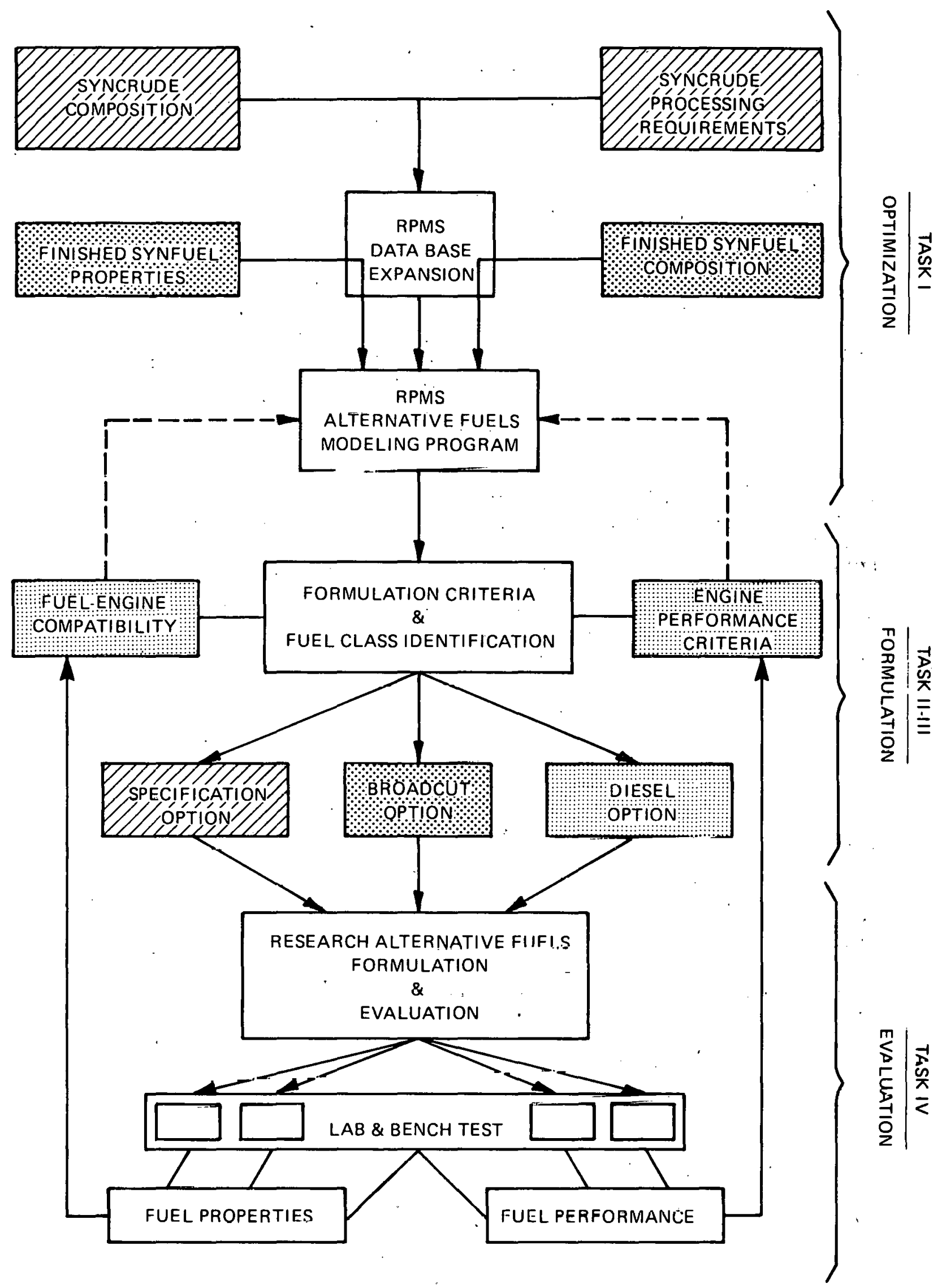

FIGURE 1.1 IDENTIFICATION, FORMULATION AND EVALUATION OF ALTERNATIVE HIGHWAY TRANSPORTATION FUELS 
- Section VI, Results and Discussion, presents summaries of results and then examines specific area in more detail on products, raw materials, energy consumption and investment costs. The numerous tables and figures are arranged by category in groups for all three regions.

- Section VII, Conclusions, analyzes results in several areas to compare impacts of the major variables on the fuel, inputs and processing.

- Section VIII, Future Work, outlines the application of results to succeeding project phases of fuels formulation and testing.

- The Appendix contalns a list of acronyms and abbreviations, with a brief definition where needed.

\section{SECTION REFERENCES}

1. Newman, F.M., Russe11, J.A., Bowden, J.N., and Johnston, A.A., "Impact of Coal and 011 Shale Proucts on Gasoline Composition, 1976-2000, Task I-Final Report," Environmental Protection Agency Report No. EPA-460/3-76-035, December 1976.

2. Southwest Research Institute, "Identification of Probable Automotive Fuels Composition: 1985-2000," U.S. Department of Energy Report No. $\mathrm{HCP} / \mathrm{W} 3684-01 / 1$, UC-96, May 1978.

3. "Program Planning Document, Highway Vehicle Alternative Fuels Utilization Program (AFUP)," U.S. Department of Energy Report No. DOE/CS-0029, UC-96, Apr11 1978.

4. "Composition of Transportation Synfuels: R\&D Needs, Strategies and Actions (Conference Proceedings)," DOE Report No. CONF-7810176, June 1979.

5. Project Planning Document, Highway vehicle Alternative Fuels Utilization Program (AFUP)," U.S. Department of Energy Report No. DOE/CS-0093, UC-96, July 1979.

6. "Alcohol Fuels Prugram Plan," U.S. Department of Energy Report No. DOE/US-0001/2, March 1978. 
This section describes the planning to make the study a realistic representation of probable future developments. It also establishes the framework for the optimization cases.

A. Time

Predictions were developed for the year 1995. Substantial shale o1l and coal oil production is expected by that date. In the 15 years between now and then, there will be time for assumed changes in engine types to have significant effects on the vehicle population.

\section{B. Location}

Syncrudes are expected to have major 1mpart in the Inland states. The East, West, and Gulf Coasts regione arc reasonally well supplied with criide oils from other sources and are not accessible by existing pipelines from the source of western shale oils in Colorado, Utah and Wyoming. Gulf Coast refining capacity is about $40 \%$ of the U.S. total and the projected syncrude volume would have minor impact on products in that region. Source of coal syncrudes is more difficult to predict but coal resources are avallable in all three regions defined for the study as well as the Gulf and East Coasts.

Regional definitions were developed considering the following factors:

- Processing plants near source of production or served by available pipelines or other bulk transportation.

- Aleas of common product quality and similar production objectives.

- Avallability of tata on crude supply, product demand, and transfers of crude and products across regional boundaries.

The regions selected for the study are shown on the map on Figure 2.1 and include the following states:

Rocky Mountains
Colorado
Montana
New Mexico
Utah
Wyoming

\begin{tabular}{ll}
\multicolumn{1}{c}{ Mid-Continent } & Great Lakes \\
Arkansas & Illinois \\
Kallsas & Indiana \\
Miagnuit & Kentucky \\
Oklahoma & Michigan \\
Texas (North of & Minnesota \\
Dallas-Ft. Worth) & Ohio \\
& Wisconsin
\end{tabular}

C. Syncrude Ava1lability

A forecast of $300,000 \mathrm{~B} / \mathrm{D}$ shale ofl production in 1995 was derived from a study by J.S. Hutchins, "O11 Shale 1979 and the $\$ 3$ Tax Credit", 


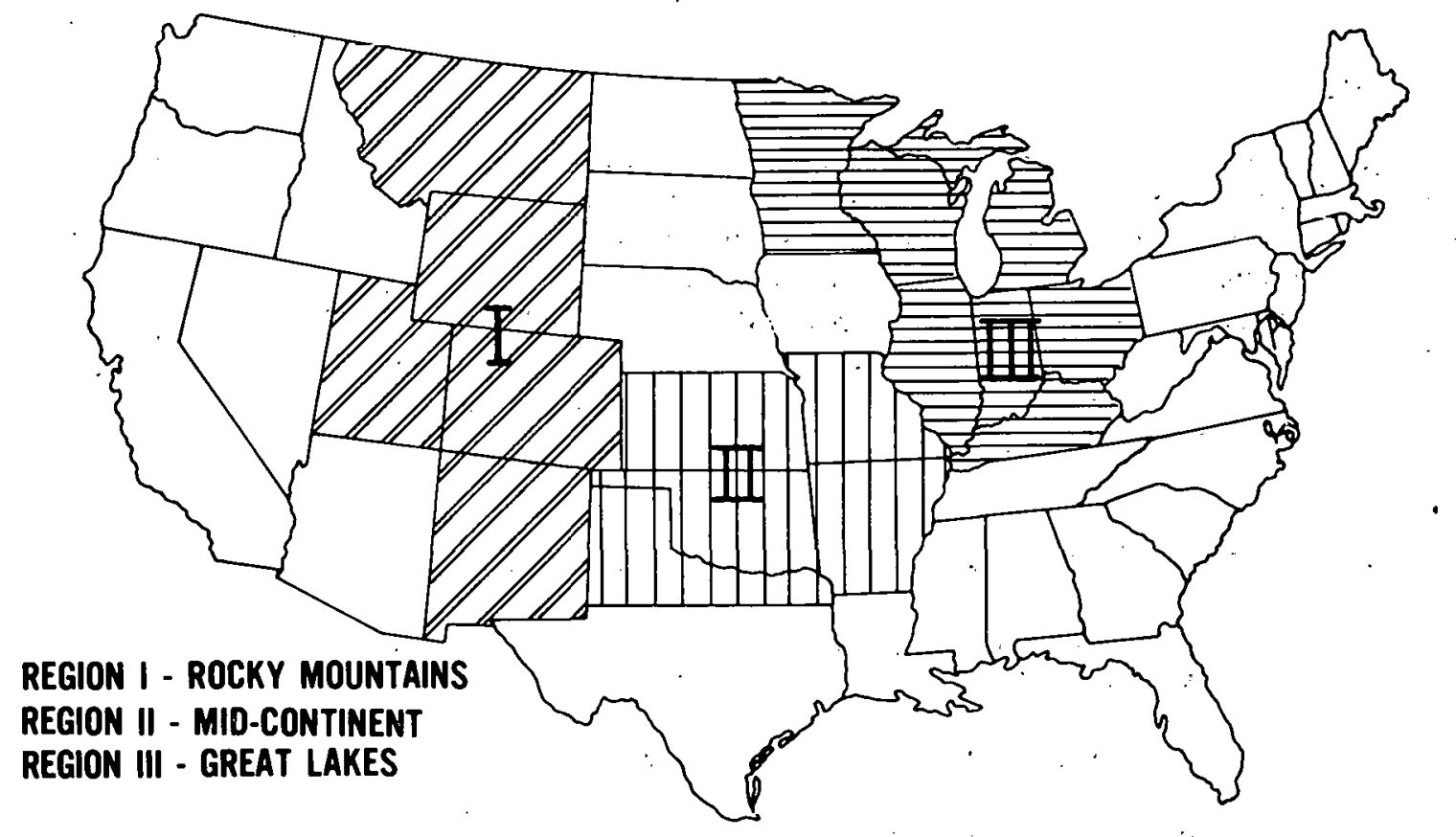

FIGURE 2.1 REGIONS FOR COPPOSITE FUELS PRODUCTION MODELS 
presented at the Twelfth 0il Shale Symposium, Golden, Colorado in April, 1979. This forecast considered economic, environmental and technological factors and concluded that some modest economic incentive was necessary to have any shale otl production. An article in the Wall street Journal of August 16, 1979 reported that 200,000 B/D by the early 1990's was considered both feasible and probable.

Simllar forecasts were not available for coal liquids. However, coal has the same obstacles to overcome in economics, environment, and technology. Since coal oil development was behind shale oil and costs were somewhat higher, a forecast of $200,000 \mathrm{~B} / \mathrm{D}$ coal liquids appeared to be a reasonable basis. (Coal ofl is used in this report for liquids derlved from coal. The term was adopted by API in 1966 and no longer applies to kerosene from petroleum.)

Since the time these forecasts were made, sume naliund ubjecllves have been revised as a result of changes in international relations and imported crude supply patterns. Federal incentives have been provided to encourage process development and syncrude production from shale and coal. Total volumes as $\mathrm{h} 1 \mathrm{gh}$ as $2,500,000 \mathrm{~B} / \mathrm{D}$ of syncrudes have been proposed, although that level may not be possible to attain in the next 10 to 15 years.

The subject project considered $500,000 \mathrm{~B} / \mathrm{D}$ synthetic crudes in each of three regions. This may be interpreted as a total $1,500,000 \mathrm{~B} / \mathrm{D}$. in all three regions to make results more consistent with future possible developments.

\section{Product Options}

Baseline projections were planned for each region to set 1995 product demand assuming conventional crudes and products. Syncrudes then would be added to replace a portion of the raw material supply. Product variations which were to be evaluated in each region include:

- Conventional products

- Maximum diesel fuel (1imit set by refinery parameters)

- Maximum broadcut fuel (limit related to engine avallability)

E. Gasoline Supplement Options

Four blending components were selected for use in the study. These are:

- Methanol

- Ethanol

- Methyl-tertiary-butyl ether (MTBE)

- Synthetic naphtha from methanol 
These are materials with potential for usage in all regions and with adequate literature data for evaluation. Other similar components may be limited in supply or distribution or were lacking in data availability.

F. Case Study Schedule

Table 2.1 presents the final schedule of cases included in the study for all regions.

The plan allows the evaluation of varying from conventional product demand to maximum diesel and broadcut fuels with shale and coal oils in all three regions. The four gasoline supplements are used in the Rocky Mountain Region where synthetic crudes are at the highest concentration in plant charge. Broadcut fuels are evaluated with petroleum as we11 as synthetic crudes in all regions.

A brief description of the cases is given near the beginning of Section $V I$, to supplement the Table 2.1 Schedule.

\section{G. Projection of New Engtne Penetration}

A projection of potential market penetration by new engine types was needed to establish a maximum level of product demand for diesel and broadcut fuels that could be forecast for 1995 .

A convenient relationship between vehicle age and vehicle miles traveled (VMT) has been published by DOE ( 1 ):

\begin{tabular}{cr} 
Vehicle Age, Years & $\%$ of Total \\
\hline 1 & 17.1 \\
2 & 14.3 \\
3 & 12.6 \\
4 & 11.1 \\
5 & 10.0 \\
6 & 8.8 \\
7 & 7.4 \\
8 & 5.8 \\
9 & 4.4 \\
10 & 3.0 \\
$11+$ & 5.5
\end{tabular}

Assumptions of rate of introduction of new vehicles or engines then can be used to generate a curve of VMT which is directly related to market penetration. For example, if a new vehicle accounts for $10 \%$ of sales in the first year, $20 \%$ of sales in the second year and on to $100 \%$ of sales in the tenth year, a curve as in Figure 2.2 is obtained. 
TABLE 2.1 PROJECT CASE STUDY SCHEDULE

\begin{tabular}{|c|c|c|c|c|c|c|c|c|c|c|c|c|c|c|c|c|c|c|c|c|c|}
\hline \multirow[b]{2}{*}{ Case No. } & \multicolumn{16}{|c|}{$\begin{array}{l}\text { RCOKKY MOUNTAI } \\
\text { REGICN }\end{array}$} & \multicolumn{5}{|c|}{$\begin{array}{l}\text { MID-CONTINENT \& } \\
\text { GREAT LAKES (Separate) }\end{array}$} \\
\hline & 1 & 2 & 3 & 4 & 5 & 6 & 7 & 8 & 9 & 10 & 11 & 12 & 13 & 14 & 15 & 16 & 1 & 2 & 3 & 4 & 5 \\
\hline \multirow{4}{*}{$\begin{array}{l}\text { Crudes } \\
\text { Petroleum } \\
\text { Shale 011 } \\
\text { Coal 011 }\end{array}$} & & & & $\cdot$ & & & & & & & & & & & & & & & & & \\
\hline & $\bar{x}$ & $\mathrm{x}$ & $\bar{x}$ & 8 & $\bar{x}$ & $\bar{x}$ & $\bar{x}$ & $\bar{x}$ & $\bar{x}$ & $x$ & $\bar{x}$ & $\bar{x}$ & $\bar{x}$ & $\bar{x}$ & $\bar{x}$ & $\bar{x}$ & $x$ & $\bar{x}$ & $\bar{x}$ & $\bar{x}$ & $\bar{x}$ \\
\hline & & $\bar{x}$ & $\bar{x}$ & $\bar{z}$ & & & & $\bar{X}$ & $\bar{x}$ & $\bar{x}$ & $\bar{x}$ & & & & & & & $\bar{x}$ & $x$ & $\bar{x}$ & \\
\hline & & & & & $\bar{x}$ & $\bar{x}$ & $x$ & & & & & $\bar{x}$ & $\bar{x}$ & $\bar{x}$ & $\bar{x}$ & & & $\bar{X}$ & $\bar{x}$ & $\bar{x}$ & \\
\hline \multirow{4}{*}{$\begin{array}{l}\text { Fuel Types } \\
\text { Conventional } \\
\text { Max Diesel } \\
\text { Broadcut } \\
\end{array}$} & & & & & & & & & & & & & & & & & & & & & \\
\hline & $\mathrm{X}$ & $\mathrm{x}$ & & & $\mathrm{X}$ & & & $\bar{X}$ & $\mathrm{x}$ & $\mathrm{X}$ & $\mathrm{X}$ & $\bar{x}$ & $\bar{x}$ & $\bar{X}$ & $\mathrm{x}$ & & $\bar{x}$ & $\bar{x}$ & & & \\
\hline & & & $\bar{x}$ & & & $\bar{x}$ & & & & & & & & & & & & & $\mathrm{X}$ & & \\
\hline & & & & $\bar{r}$ & & & $\mathrm{X}$ & & & & & & & & & $\bar{x}$ & & & & $\mathrm{x}$ & $\mathrm{x}$ \\
\hline \multirow{5}{*}{\begin{tabular}{|l|} 
Blend Components \\
Methanol \\
Ethanol \\
MTBE \\
Synthetic Naphtha \\
\end{tabular}} & & & & & & & & & & & & & & & & & & & & & \\
\hline & & & & & & & & $\bar{x}$ & & & & $\bar{x}$ & & & & & & & & & \\
\hline & & & & & & & & & $x$ & & & & $\bar{x}$ & & & & & & & & \\
\hline & & & & & & & & & & $X$ & & & & $\mathrm{X}$ & & & & & & & \\
\hline & & & & & & & & & & & $\bar{x}$ & & & & $\bar{x}$ & & & & & & \\
\hline
\end{tabular}




\section{FIG. 2.2 PER CENT VEHICLE MILES - NEU CARS}

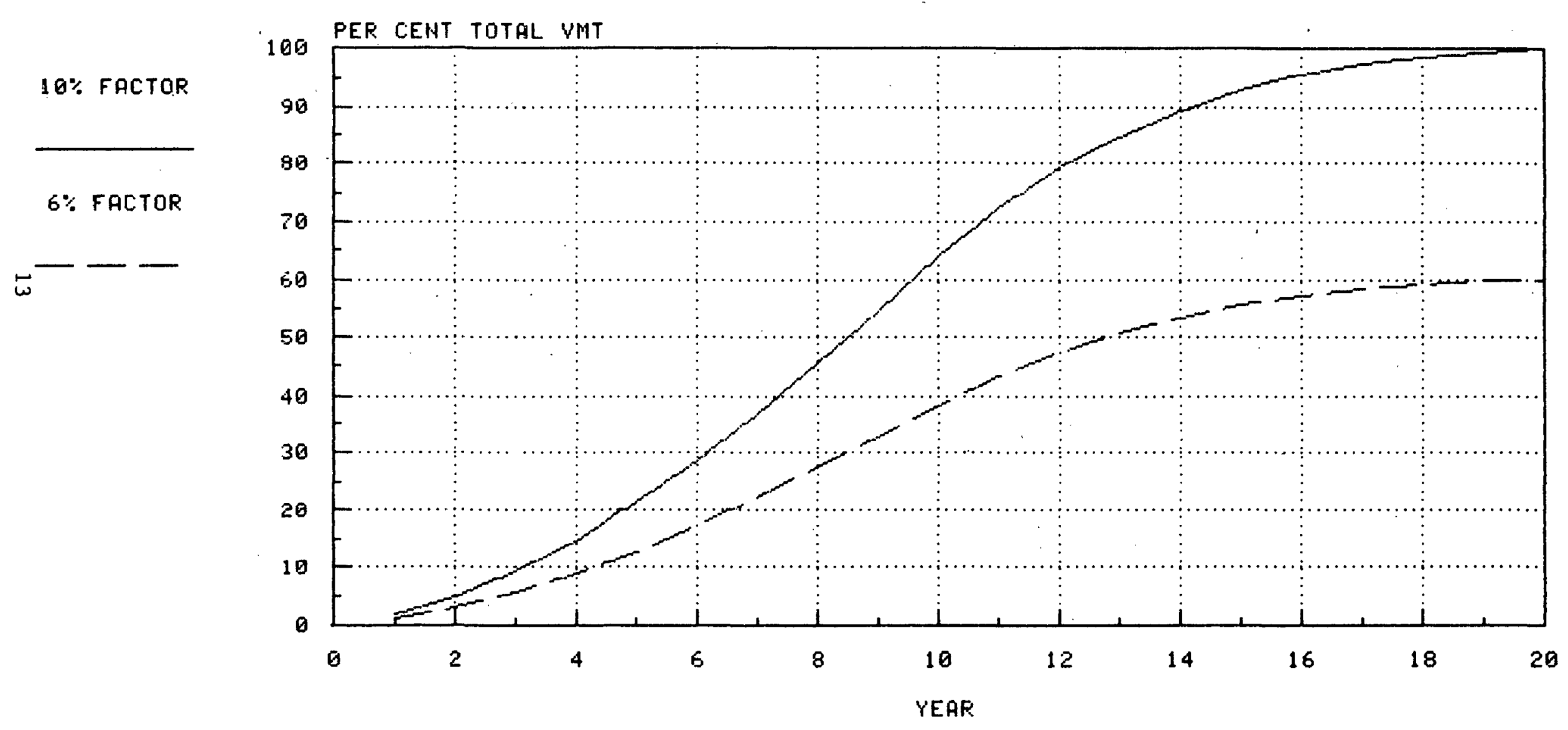


Using a new vehicle factor of $6 \%$ in the above relationship produces a more conservative projection also plotted on Figure 2.2. The percentage of total VMT for two factors at 5-year intervals is:

\begin{tabular}{ccc} 
Year & \multicolumn{2}{c}{ Percentage of Total VMT } \\
\cline { 2 - 3 }-5 & 21.3 & $6 \%$ Factor \\
10 & 64.1 & 12.8 \\
15 & 92.8 & 38.5 \\
20 & 100.0 & 55.7
\end{tabular}

Market penetration of vehicles with engines capable of using broadcut fuels was projected on the following schedule. Engine development would proceed on Stirling, turbine or a sultable internal combustion engine which would be introduced in the 1985 model year. If used in $6 \%$ of new vehicles that year and an additional $6 \%$ each following year, the new engine wuld account for $38.5 \%$ of total VMT in ten years. Although somewhat hypothetical, this derivation provides a reasonable basis for the potential $40 \%$ of the vehicle population with the new type engine in the 1995 broadcut fuel cases.

Prcdictions have been made of diesel engine sales as part of fuel forecasts. DuPont estimated 5\% of all cars and light trucks sold in 1985 would be diesel-powered.(2) A sensitivity analysis allowed this value to go as high as $25 \%$. A forecast from Ethyl Corporation (3) estimated diesel sales to 1993. A moderate extrapolation of their schedule to 1995 and use of the VMT relationship described above gives a projection of diesel automobiles and light trucks in the total vehicle population, as follows:

$\begin{array}{ccc}\text { Year } & \begin{array}{l}\text { Diesel as Share of } \\ \text { Car Market, \% (3) }\end{array} & \begin{array}{l}\text { Diesel Vehicles } \\ \text { on Road,\% (est.) }\end{array} \\ 1980 & 1.0 & 0.2 \\ 1985 & 6.0 & 2.9 \\ 1990 & 11.3 & 7.5 \\ 1993 & 14.7 & 10.7 \\ 1995 & 17.1 \text { (Est.) } & 12.9\end{array}$

This estimate of $12.9 \%$ diesels in the 1995 11ght vehicle population would apply to the baseline prediction for that year. The percentage of diesels could increase more rapidly than these projections because of enthusiastic acceptance by the public and the desire to improve fuel ecunomy for resource conservation. Maximizing diesel fuel in this study was desirable to facilitate measuring the effects with synthetic crudes. other studies have shown that the diesel fuel population will probably be $11 \mathrm{mited}$ by capability of refineries to increase diesel fuel production. Therefore, a definition was needed for a reasonable maximum level of diesel fuel production.

A study by Bonner \& Moore concluded that a maximum of about $60 \%$ of total motor fuel could be supplied as diesel fuel.(4) About half of this 
amount was "new" diesel fuel produced as an increment over the baseline projection. The limiting quantity was the amount of diesel components 1 present in the crude plus diesel components produced by conversion processes with present technology while meeting other products demands. At that point the ratio of gasoline to total distillate was 0.54 .

Amoco investigated the economics of increasing diesel fuel while decreasing gasoline production. (5) They found that about $30 \%$ of total motor fuel could be supplied as diesel fuel with existing technology without unusual problems. An additional increment of diesel fuel was provided for off-highway use, amounting to about $8 \%$ of total motor fuel. A more recent study was made to update and expand the previous work. (6) Product slates were forecast for 1995 and proportions of gasoline and $\bar{d}$ lesel fuel were varied. Maximum diese1. fuel production was at 0.7 ratio of gasoline to total distillate. The conclusion was that additional diesel fuel amounting to about $30 \%$ of total motor fuel could be produced and, in fact, was the optimum production level to maximize transportation miles per barrel $0^{\text {* }}$ crude (along with an optimum gasoline octane level).

A similar study was made by Exxon in the 1990-2000 time frame. (9) Maximum savings in refining cost and energy usage occurred when diese $\bar{l}$ fuel was increased from the $10 \%$ leve 1 to $46-55 \%$ of total automotive fuel, equivalent to about 0.66 to 0.49 gasoline to total distillate ratio. Higher levels of diesel fuel were made at increasing cost to a maximum feasible $73 \%$ of transportation fuel or 0.30 gasoline to distillate ratio.

Based on the above four studies, 1 t was concluded for the 1995 maximum diesel cases that the equivalent of $30 \%$ of the vehicle population could be shifted from gasoline to diesel fuel. Stated another way, this assumes that an additional $30 \%$ of the vehicles on the road in 1995 were produced with diesel engines instead of gasoline engines.

An additional correction was applied on product volumes to adjust for the difference in average fuel economy of the vehicles with different engine types. Data were available on an equivalent ratio of engine power to vehicle weight which stated a $35-39 \%$ increase in miles per gallon for diesel over gasoline.(7) Another source reported that a diesel engine gives 36\% better MPG at the same horsepower and inertia weight. (8) A factor of $35 \%$ was selected for use in the maximum diesel cases, although a diesel engine at this economy level may not assure the same acceleration performance. More precisely, the volume of gasoline replaced was multiplied by $1.00 / 1.35$ or 0.7407 to arrive at the equivalent volume of diesel fuel. In effect, this method assumes a constant number of miles driven with motor fuel production in each regional series of cases.

A similar adjustment was made for broadcut fuel. Efficiency of a future turbine, Stirling or spark-assisted diesel engine should approach that of a diesel engine. However, average fuel economy would be about $92 \%$ of the diesel because of lower BTU content of the broadcut fuel. Therefore, the broadcut fuel would obtain $24 \%$ more miles per gallon than gasoline. Gasoline volume displaced was multiplied by $1.00 / 1.24$ or 0.8065 to determine the equivalent volume of broadcut fuel.

A summary of the product volumes for maximum diesel and broadcut fuel cases is given on Table 3.13 in the following section. 
1. Shonka, D.B. (Ed), "Transportation Energy Conservation Data Book," Edition 3, ORNL-5493, Department of Energy and Oak Ridge National Laboratory, February, 1979, Chapter 1, page 1-103.

2. Bettoney, W.E., Finnerty, R.G. Jr., and Rogers, J.E. Jr., "Gasoline Octane Quality and Demand," E.I. Du Pont De Nemours \& Co., API 44th Refining Mid-Year Meeting, May 1979, pages 22-23.

3. Michalski, G.W. and Unzleman, G.H., "Effective Use of Antiknocks During the 1980's," Ethyl Corporation, API 44th Refining Mid-Year Meeting, May 1979 , page 16 .

4. Frederick, F.P., Moore, J,F, Bonner, J.S., Dickson, J.C., and Karvelas, L.P., "The Impact of Automotive Fuel Changes on the U.S. Refining Industry," Bonner \& Moore Associates, Inc., FE-2216-1, Energy Research and Development Administration, ERDA 76-40, February 1976, pages 9-50.

5. Wagner, T.U., "Ficnnomics of Manufacturing Automotive Diesel Fue1," Amoco Oil Co., 1977, SAE Paper No. 770758.

6. Lawrence, D.K., Plautz, D.A., Keller, B.D., and Wagner, T.0., "Automotive Fuels-Refinery Energy and Economics," Amoco 011 Co., February 1980, SAE Paper No. 800225 .

7. Springer, K.J. and Baines, T.M., "Emissions From Diesel Versions or Production Passenger Cars," Southwest Research Institute and Environmental Protection Agency, 1977, SAE Paper No. 770818.

8. "Conventional Engine Technology for Automotive Applioation," Jet Propulsion Laboratory, California Institute of Technology at Department of Energy Contractor Coordination Meeting, Dearborn, Michigan, October 1979.

9. Kant, F.H.; Cunnlngham, A.K., and Farrier, M.H., "Effects of Changing the Proportions of Automotive Distillate and Gasoline Produced by Petroleum Refining," Exxon Research and Engineering Co., PB-236 900. Environmental Protection Agency, EPA-460/3-74-018, July 1974. 
With the scenario framework and the case study outline from the preceding section completed, the next task was development of fuels production models. The principal methodology for this effort was the Refinery and Petrochemical Modeling System (RPMS) developed by Bonner \& Moore Associates of Houston, Texas. This system has an extensive data base which facilitates building refinery models. This section describes the basis for construction of the models to represent the refining industry in each region which will be likely to process syncrudes in the future. The development is outlined through the running of three regional base cases for 1995 operation.

A. The Refinery and Petrochemical Modeling System

The RPMS is a computer-based management tool. Consisting of both processors and extensive data libraries, the system permits the rapid construction and solution of linear programming models to address complex economic analysis and planning problems within the refining and petrochemical industries.

It is necessary to understand that RPMS is not a model. It is a system for the creation, validation, documentation and use of mode1s. It accepts technology-oriented statements, logical requests and data tabulations and converts these into a Linear Programming (LP) matrix and reports. The user may supply data explicitly, or the system may retrieve data from any of several data bases or libraries.

RPMS is not an optimization program. Rather its function is the generation of models for optimization and associated reports. It requires the support of a mathematical programming system in order to perform the actual model optimization.

Finally, RPMS is not a matrix generation and reporting language. Most of the RPMS programs are written in the Bonner \& Moore GAMMA language for matrix generation and reporting. The library files are also in GAMMA format. RPMS is a higher-level system using GAMMA to collect the data and to program the modeling and data-handling techniques appropriate to the refining and petrochemical industries.

The DATA Component. The heart of the basic system is the DATA processor. This program receives the user input data (in the form of GAMMA tables and lists) specifying the characteristics of the model to be constructed. After analyzing the content of this input, the program selectively retrieves from user and system libraries the additional data needed to support the user's modeling requests. All of the data analyses and calculations required for generation of the matrix are then performed by the DATA program itself.

The CHEK Component. The CHEK (check) program performs a large number of numerical and logical checks on the completed data structure produced by the DATA program. For example, each potential process unit operating variable is checked for exact material balance closure, and every refinery stock is tested to verify that the completed model will include both producing 
and consuming activities. This program produces a condensed "logical flow sheet" of the configuration to be represented by the finished model, indicating all raw materials, products, inventories, blends, process units, and stream origins and dispositions.

The DISP Component. The DISP (display) program, like the CHEK program, does not contribute directly to the generation of the model. Its function is to prepare a formatted, documentation-quality set of reports of the final technological data entering the model. In addition to all usersupplied data describing such things as raw material availabilities and costs, product demand structures and prices, etc., it includes a complete display of all process and blending data retrieved from the library files or developed by the DATA program.

The MATX Component. The MATX program has two functions: the conversion of the DATA program output into the proper input format for the LP, and the generation of the report controls. It has been separated from the DATA program so that its functions will not be executed needlessly when the CHEK or DISP reports show errors of sufficient magnitude to require data revision and reexecution of the DATA program.

The MMOD Component. Finally, the MMOD program is used to generate model revisions from user input in a format similair to the DATA program input. In a sense, it may be thought of as combining the functions of both the DATA and MATX programs with respect to model changes, since it is responsible for input and analysis of the user revision requests, validation of these requests against the problem structure created by the DATA program, and their output in a form suitable as input to the LP program itself. The MMOD input and output provides documentation of model changes in a format consistent with the original problem statement.

RPMS Solution Reports. Solution analysis reports produced by RPMS

fall Into elght groups:

1) New Facility Investment Summary

2) Overall Material and Economic Balances

3) Blending Summaries (Recipe and Specification).

4) Stream Production/consumption Reports

5) Utility and Chemical Reports

6) Final Economic Summary

7) Uult Dutall Rupurtb

8) Miscellaneous Status Reports

B. Refinery Mode1

The RPMS wae ueed to develop a lincar programming model of a refinery. The model is a complete representation of crude conversion into final products by processing in the various refinery operating units. A linear programming model is a set of mathematical equations in which the variables are related to each other in linear combination. The model represents, in mathematical terms, the operation of a variety of refinery process units and the flow of petroleum fractions among these units. The representations describe how the units respond to changes in feedstock qualities and operating conditions. The equations for each unit allow for consumption of utilities 
such as fuel, steam, and electricity and the investment costs associated with building new units or expanding capacity of existing units. The model provides for changes in stream flows and unit operating conditions to make a desired set of products. The properties of the individual components of a product blend are blended linearly to meet product inspections. The model is driven either to minimize costs to meet a specific product slate or to maximize refinery cash flow.

When individual refiners use linear programming to plan their operations and strategles, the models are tailored to their specific refinery and to the nature of the planning questions to be answered. When the objective of a study is to provide estimates of how the refining industry will respond to several alternative situations, as in this present study, a model tailored to a specific refinery is not appropriate. Instead, a "composite" model of the refineries in a given region is used.

In a composite model, the ratios between the various process unit capacities represented in the model are the same as the ratios between the total of the process unit capacities existing in the section of the refining industry under study. For example, if the sum of the catalytic cracking unit capacities in a region being studied is $40 \%$ of the sum of the crude distillation capacities, then the catalytic cracking capacity represented in the model will be $40 \%$ of the crude distillation capacity represented in the same model. The selection of absolute size for one of the processes (usually the crude distillation unit) then determines the size of all the other process units.

So far as process yields and variable operating costs are concerned there are no economy of scale effects. The absolute size selection can be made at the discretion of the analyst. A 100,000 B/D size for the existing crude distillation capacity was chosen for the composite refinery model for the Rocky Mountain region.

The representation of each individual process. in the composite model is designed to simulate typical yields, operating costs, operating flexibilities, etc. for the process type. The simulation of a specific process is the same for existing plants as for new plants. When capacity above the existing level is utilized, the fixed costs associated with the new capacity are included in the determination of an economic optimum solution.

Economies of scale are important when sizing new units, so the selection of new unit sizes must not be arbitrary, as was the selection the existing refinery size. The most acceptable results for industry studies are produced when the costs associated with new process capacities are based on the "typical" sizes for such units as may have been recently constructed or for which planned construction has been announced.

If the results of the study show $43,000 \mathrm{~B} / \mathrm{D}$ of new capacity will be needed by 1995 and the typical size of a new unit is $10,000 \mathrm{~B} / \mathrm{D}$, then 4.3 new units would be expected to be added to the industry. 


\section{Refinery Configurations-1979 Basis}

Refinery Configuration for the 1979 basis is shown pictorially in Figure 3.1; 1979 configurations as a percent of atmospheric crude unit capacity are shown in Table 3.1. Unit capacities were obtained from the "Annual Refining Report" published by The 011 and Gas Journal. (1) The refinery capacities reported are as of January 1, 1979. The configurations were calculated by summing the unit capacities excluding topping refineries which are very simple operations usually containing only an atmospheric distillation unit but no conversion processing such as a catalytic reformer or catalytic cracker.

There are 28 to 32 refineries in each region. Comparison of the three regions in Table 3.1 shows principal similarities and differences. The Great Lakes Region has the greatest refinery capacity, nearly twice as much as the Mid-Continent and five times as:much as the Rocky Mountains. The most notable differences in configuration are the larger percentages of catalytic cracking, alkylation and coking in the Mid-Continent and Great Lakes reglons relative to the Rocky Mountains. These are due to historical feedstock avallabilities and product demands which determine individual refinery configurations.

Refinery Size. Inftial refinery configurations were based on the 1979 figures reported in Table 3.1\% In the Rocky Mountains Region crude capacity was normalized to $100,000 \mathrm{~B} / \mathrm{D}$ before beginning the computer runs. In the Mid-Continent and Great Lakes Regions the average capacities reported in Table 3.1 were used as a basis. The differing choices reflect the personal preference of the analysts in developing each of the regional models.

D. Crude Supply Fórecasts

Crude 0il Production. Crude oll production was forecast from 1975 state-by-state production data obtained from U. S. Bureau of Mines reports. Statistics are reported for Petroleum Administration for Defense (PAD) Districts of the U.S. as shown on the map on Figure 3.2 .

The sweet/sour crude breakdown was determined from a review of a Bureau of Mines report entitled "Sulfur Content of Crude 0il" which. analyzed 1971 production. The basic data in this report were adjusted for significant sweet/sour additions from 1971 through 1975. Production was decreased in future years based on the historical rate of production decline from 1971 to 1976. These are as follows:

\begin{tabular}{rrr} 
PAD District & & Decline \\
\hline & & 0 \\
II & $\ddots \because$ & 3.9 \\
II & & 3.5 \\
III & & 1.1 \\
IV & & 2.7 \\
V & &
\end{tabular}

These decline rates Imply that U.S. production based on 1975 capacity will decline from 8360 MBPD to 4430 MBPD in 1995 as shown in Table 3.2.

In addition to this volume, new production is expected from those sources shown on Table 3.2. These additions indicate that total production 


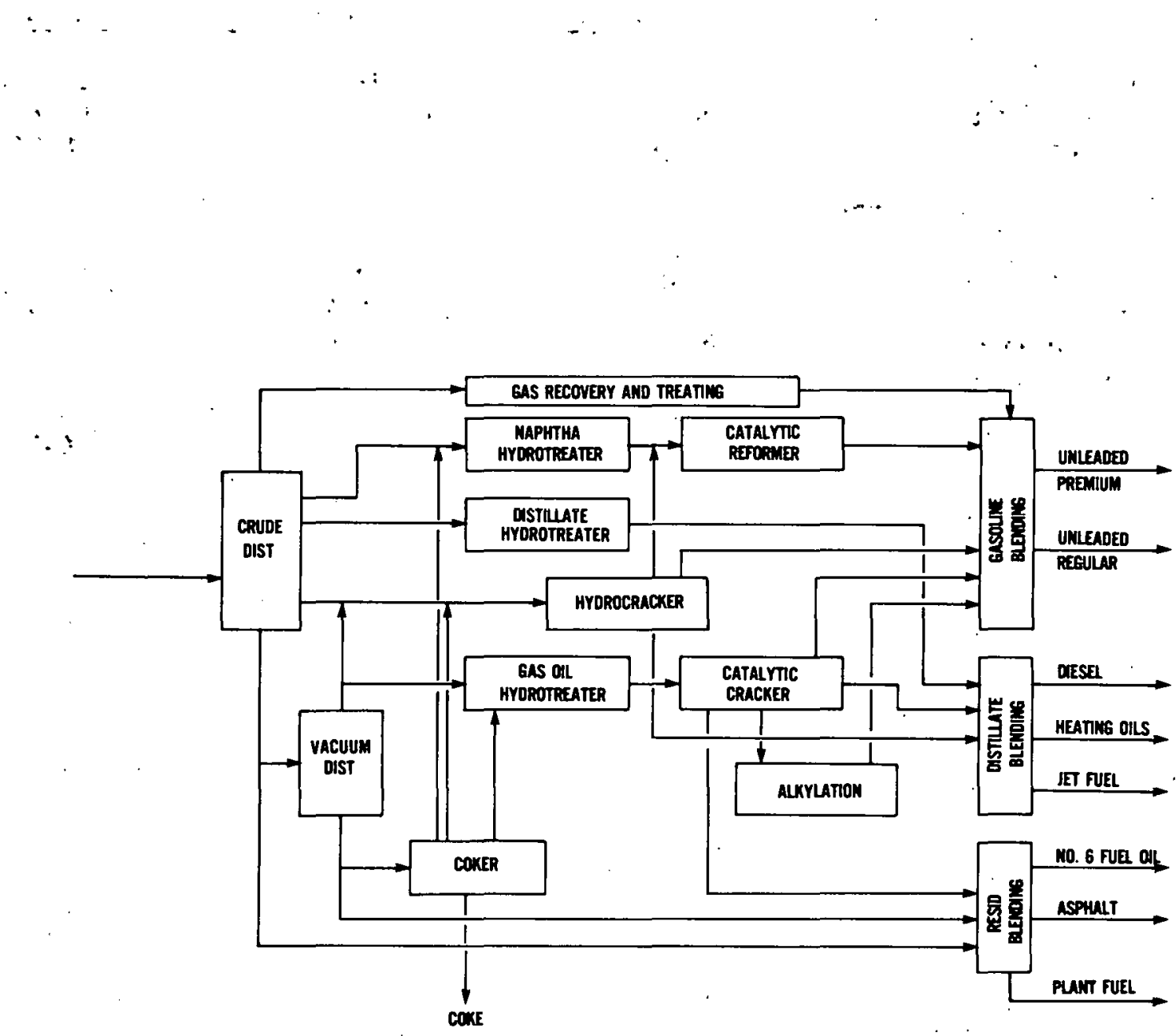

FIGURE 3.1 REFINERY CONFIGURATION 1979 BASIS 
TABLE 3.1 REFINERY CONFIGURATION 1979 BASIS

\section{Rocky Mountains Mid-Continent Great Lakes}

No. of Refineries

Crude Capacity, BPSD

Average Capacity, BPSD

UNIT CAPACITIES, \% OF CRUDE

28
630,700
22,530

31.5

20.5

30.3

1.0

5.4

2.5
28.5

23.2

36.0

0.5

9.2

6.8
37.8

22.4

34.5

4.8

6.3

6.2

Coking 


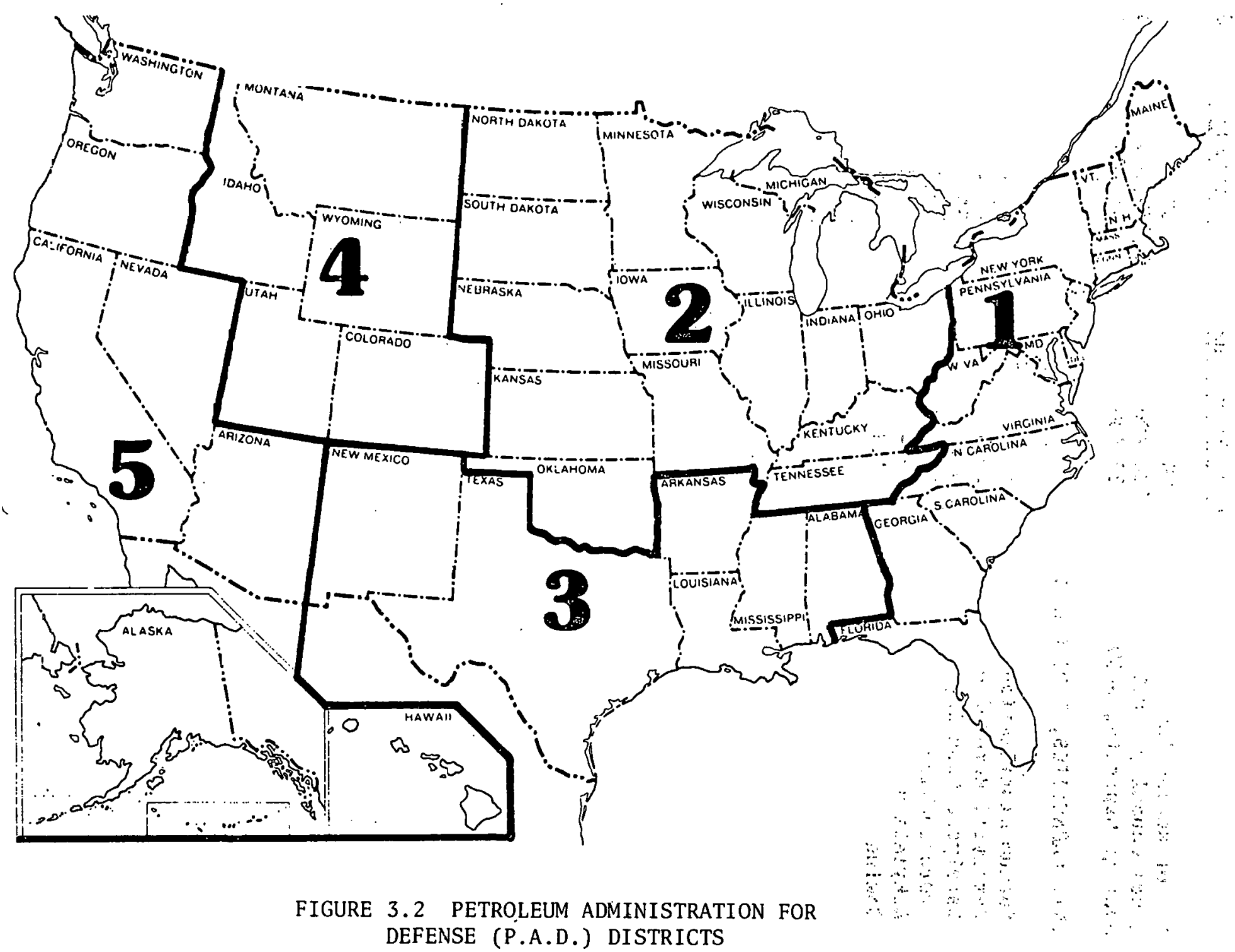


TABLE 3.2 U.S. CRUDE PRODUCTION

MBPD

PADD I

Florida

New York

Pennsylvania

Virginia

W. Virginia

Sub-Total

\begin{tabular}{lll}
\multicolumn{3}{c}{1975} \\
\hline Sweet & Sour & Total
\end{tabular}

\begin{tabular}{lll} 
& 1995 \\
\hline Sweet & Sour $\quad$ Total \\
\hline
\end{tabular}

TADD II

I11inots

Indiana

Kansas

Kentucky

Michigan

Missour1

Nebraska

N. Dakota

ohio

Oklahoma

S. Dakota

Tennessee

Sub-Total

PADD III

Alabama

Arkansas

Loulsiana

Mississippi

New Mexico

Texas

Sub-Total

\begin{tabular}{rrrrrr}
- & 114.7 & 114.7 & - & 114.7 & 114.7 \\
2.4 & - & 2.4 & 2.4 & - & 2.4 \\
10.7 & - & 10.7 & 10.7 & - & 10.7 \\
- & - & 0.0 & - & - & 0.0 \\
6.8 & - & 6.8 & 6.8 & - & 6.8 \\
\cline { 2 - 4 } 19.9 & 114.7 & $\frac{6.9}{134.6}$ & 19.9 & 114.7 & 134.6
\end{tabular}

$$
71.5
$$

12.5

109.1

20.7

55.2

0.1

7.4

35.2

26.5

370.0$$
114 \cdot 7
$$

$-\quad 71.5$
$-\quad 12.7$

71.5
12.7

$\begin{array}{rr}.2 & 12.7 \\ 52.8 & 161.9\end{array}$

32.2

5.6

49.2

9.3

11.7

20.7

0.1

9.4

66.9

24.9

0.2

16.8

20.8

56.0

32.1

76.9

446.9

1.3

1.3

$\frac{2.1}{710,3}$

$\frac{-}{178.8}$

$\frac{2.1}{889.1}$

$$
-
$$

3.3

15.9

12.0

166.9

$-$

$\frac{0.9}{330.2}$

36.9

44.9

33.5

10.3

3.4

34.6

1795.6

76.2

127.6

34.6

1.35 .0

93.0

259.3

$\frac{2153.4}{4086.5}$

124.3

3346.6

$\frac{1193.2}{1524.7}$

$\begin{array}{r}16.4 \\ 5.0 \\ 842.5 \\ 17.0 \\ 66.2 \\ 1055.2 \\ \hline 2002.3\end{array}$

1.7

17.0

37.3

45.6

60.9

0.1

32.2

23.8

5.7

73.0

$-$

9.3

5.3

30.2

0.1

7.5

4.2

25.3

2.5

14.5

34.7

201.6

$0.6 \quad 0.6$

PADD IV

Colorado

Montana

Urah

Wyoming

Sub-Total

$\begin{array}{rrrrrr}13.1 & 90.8 & 103.9 & 10.5 & 72.8 & 83.3 \\ 42.0 & 48.0 & 100.0 & 33.7 & 38.5 & 72.2 \\ 98.0 & 10.4 & 108.4 & 78.6 & 8.3 & 86.9 \\ 130.7 & 217.9 & \frac{348.6}{650.9} & \frac{104.8}{227.6} & \frac{174.8}{294.4} & \frac{279.6}{522.0}\end{array}$


TABLE 3.2 U.S. CRUDE PRODUCTION(CONT'D)

MBPD

\begin{tabular}{|c|c|c|c|c|c|}
\hline \multicolumn{3}{|c|}{1975} & \multicolumn{3}{|c|}{1995} \\
\hline Sweet & Sour & Total & $\overline{\text { Sweet }}$ & Sour & Total \\
\hline
\end{tabular}

PADD V

Alaska

Arizona

165.0

1.7

26.2

191.2

1.7

California

102.3

$-$

882.8

Nevada

$\frac{-}{269.0}$

780.5

$\frac{0.3}{807.0} \quad \frac{0.3}{1076.0}$

Sub-Total

5369.0

2993.0

8362.0

95.4

1.0

59.1

TOTAL

5369.0

$\frac{-}{155.5}$

2725.5

15.1

: 110.5

$451.1 . \quad 510.2$

$\frac{0.2}{466.4} \therefore \frac{0.2}{621.9}$

$1703.3 \quad 4428.8$

\section{NEW PRODUCTION}

Expanded Yates Production (Texas)

Enhanced Recovery California 100

Oklahoma \& Texas 600

other 100

New Discoveries in Overthrust Belt

Elk Hills

(Wyoming/Idaho)

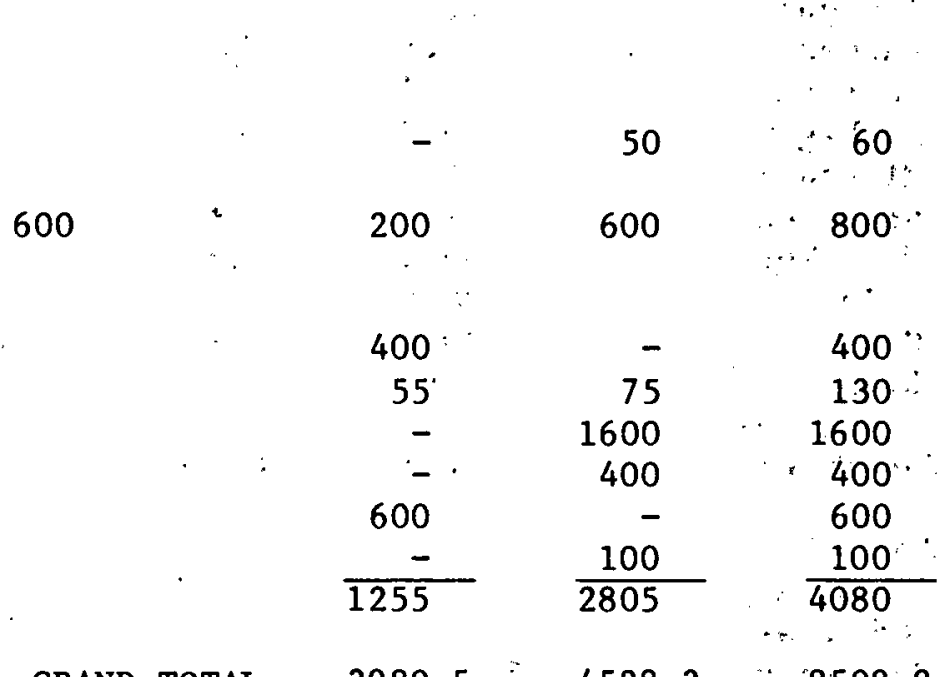

North Slope

offshore California

South Alaska

East Coast Offshore

GRAND TOTAL $\quad 3980.5 \div \quad 4528.3 \quad \because 8508.8$ 
will decrease to 8500 MBPD in 1995 from the 1978 average value of 8684 MBPD (U.S. DOE Monthly Energy Review, April 1979). These new production figures are based on a review of a number of sources including: The Energy Information Administration's Annual Report to Congress, April 1978 and miscellaneous energy studies prepared by PIRINC, She11 011, Exxon, Phillips, Mobil, Gulf 0il, Purvin and Gertz, and Pace Company.

Regional forecasts were then developed using this total crude oil forecast as a basis.

Refinery capacity for each region was obtained by using Annual Refining Survey from the Oil and Gas Journal. The capacities are those of January 1, 1979. These capacities have been further subdivided by reference to the NPRA study: "Capabilities of U.S. Refineries to Process Sweet/Sour Crude Oil" done in March 1978.

Regional capacities were extrapolated to 1995 by increasing the values by 1.5 percent/year which is the forecasted annual growth in petroleum demand froil 1979 to 1995. The break-down between sweet and sour capacity was determined by assuming all new capactity would be capable of handling sour crudes. No conversion of sweet crude capacity to sour crude feedstocks was assumed. This information is summarized in Table 3.3 and has been used to determine crude quality requirements for each region.

Regional feedstocks are summarized in Table 3.4, which shows four cases spanning the range of syncrude input. In the base case, no synthetics are processed in the refinery. When synthetics are introduced, either domestic or imported sweet crude will be backed out. Three cases could be considered for synthetics: running just shale oil, running just coal oil, or running both in combination.

Swing Crude Definition. For each region, petroleum "swing crudes" were defined whose volume would be varlable when the given volume of synthetirs was charged to the refinery. In the Rocky Mountain Region cases two crude types were defined: a low sulfur crude which was a mix of $23 \%$ of Wyoming Average (E1k Basin) and $77 \%$ Wyoming Light (Grass Creek) and a high sulfur crude which was represented by Wyoming Heavy (Steamboat Butte). Distillation curves for high sulfur and low sulfur crude are shown in Figure 3.3. Total quantity of these crudes was allowed to vary, but in a constant ratio to each other. Therefore, the swing crude was the mix of 1 nw and high sulfur crudes shown in Table 3.5 .

In the Mid-Continent Region, three crude types were defined: a local crude, an inter PADD sour, and an inter-PADD sweet. The inter-PADD sweet crude was the swing crude; the local crude was represented hy a mix of $34 \%$ M1d-Continent Average Pipeline, 27\% Kansas "A", and 39\% Oklahoma Sweet. The inter-PADD sour imports represent movements from PADD III and PADD IV. The crudes chosen to represent this $\operatorname{mix}$ were $15 \%$ Wyoming Heavy, $12 \%$ Wyoming Average, and $73 \%$ West Texas Heavy. The inter-PADD sweet imports represent movements from PADD III and IV. The crudes chosen to reprcocnt this mix were $11 \%$ Gulf Coast Average, $23 \%$ West Texas Light, 38\% South Louisiana Average, and $28 \%$ Wyoming Light. The swing crude in this region was inter-PADD sweet. The volumes of the others were fixed.

In the Great Lakes Region, four crude types were defined: a local crude, North slope, an imported sweet crude, and an imported sour. The imported sweet crude was used as the swing crude. The local crude was 
TABLE 3.3 REFINERY CAPACITY

MBPSD

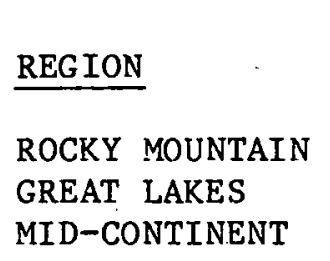

\begin{tabular}{|c|c|c|}
\hline \multicolumn{3}{|c|}{1979} \\
\hline Sweet & Sour & Total \\
\hline 498.6 & 200 & 698.6 \\
\hline 1799.4 & 1330 & 3129.4 \\
\hline 1519.5 & 100 & 1619.5 \\
\hline
\end{tabular}

\begin{tabular}{|c|c|c|}
\hline \multicolumn{3}{|c|}{1995} \\
\hline Sweet & Sour & Total \\
\hline 498.6 & 350.9 & 849.5 \\
\hline 1799.4 & 2005.9 & 3805.3 \\
\hline 1519.5 & 449.8 & 1969.3 \\
\hline
\end{tabular}

(1) 1970 capacity based on the NPRA study "Capability of U.S. Refineries to Process Sweet/Sour Crude 011," March 15, 1978.

(2) All expansions after 1979 are sour crude based expansions.

(3) 1979 capacity is based on 011 and Gas Journal Annual Refining Survey as reported in the March 26, 1979 issue. 
TABLE 3.4 FEEDSTOCKS SLATES FOR AUTOMOTIVE FUELS STUDY MBPD

$\%$

Syn

ROCKY MTN REGION

0 No Synthetics

35 Shale oil

24 Coal oil

59 Both

CREAT LAYES REEION

11 Nn Synthetios

280

280

280

280

MID-CONTINENT REGION

$\begin{aligned} 0 & \text { No Synthetics } \\ 15 & \text { Shale 0il } \\ 10 & \text { Coal 011 } \\ 25 & \text { Both }\end{aligned}$

0 No Synthetics

1380

1220

1320

1020
Domestic

Sour

350

350

350

350

10

10

10

10

450

450

450

450
Imported

Sweet

0
0
0
0

1520

$1220^{\circ}$

1320

1020

140

0

0

0
Imported Sour
Syn Total

$\begin{array}{rr}0 & 850 \\ 300 & 850 \\ 200 & 850 \\ 500 & 850\end{array}$

$\begin{array}{rr}0 & 3810 \\ 300 & 3810 \\ 200 & 3810 \\ 500 & 3810\end{array}$

2000

2000

2000

2000

0 1970

$300 \quad 1970$

$200 \quad 1970$

$500 \quad 1970$ 


\section{FIG. 3.3 ROCKY MOUNTAIH CRUDE IISTILLATION}

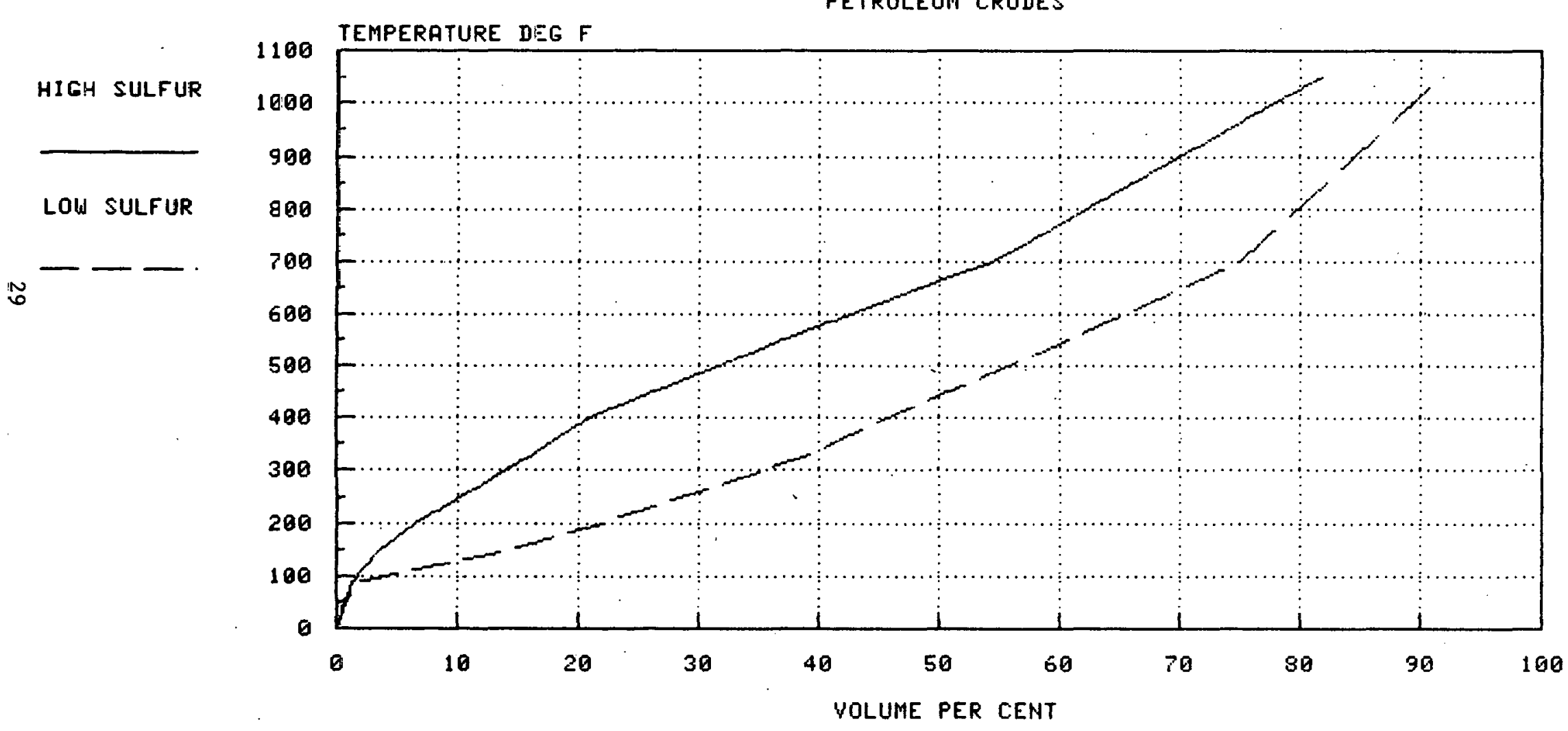


represented by a mix of $34 \%$ Mid-Continent Average Pipeline crude, $27 \%$ Kansas "A", and 39\% Oklahoma. sweet... The, imported sweet crude was represented by a mix of $16 \%$ Forcados, $19.3 \%$ Bonny, $34.4 \%$ Libyan Mix, $16.8 \%$ ohanet (Algerian), and 13.5\% Ekofisk. The imported sour mix was represented by a $\mathrm{mix}$ of $71.6 \%$ Arabian Light, $13.6 \%$ Tia Juana Medium, $9.1 \%$ Monagas (Venezuelan) and $5.7 \%$ Lagomar (Venezuelan). The swing crude in this region was imported sweet crude. The volumes of the others were again fixed.

The volumes of each of these crudes charged in the base cases in each region are shown tin Table 3.5. The compositions and volumes reported were developed from forecasts of individual PADD refinery feedstocks. The forecasts were developed based on historic data and total U. S. energy forecasts.

\section{E. Product Demand Forecasts}

Method and Basis.:. The approach used in developtng regional product demands was to develop a national energy forecast and then relate the resultant energy forecasts by sector to representative macroeconomic factors. Individual reglonal demands were then generated by ustang state projections of these same macroeconomic factors, the historical rellationship of the state to national energy use per macroeconomic factor, and then combining the state forecasts tnto regional projections. $\ldots \ldots ; \ldots \ldots$

Flgure 3.4 is an lnformation flow diagram of this approach. As indicated in the legend, the double-lined boxes are computer models. The national forecast is developed through the application of rates of growth by sector of demand. These rates of growth can be varied over any time horizon. The sources of supply to satisfy each sector demand are also projected by using a rate of growth, which can be varied with time. Conversion of energy to physical units is based on the most recent historical experience and can be varied externally. 'l'he etticilency of power generacion is also based on most recent historical experience but can be changed to reflect external information.

Demand forecasts by state were generated on the basis that the historical relationship of state energy demands by sector per appropriate economic factor to the equivalent U.S. ratio will hold into the future. Thus, the state energy demand growth rate by sector uses the national rate of growth, adjusted by the historical ratio of state to national use, and the projected state economic factor growth. This is expressed in the following equation:

$\mathrm{ROC}_{\text {seds }}=\mathrm{ROC}_{\text {sef }}+\mathrm{ROC}_{\mathrm{nr}} * \mathrm{X}$

where

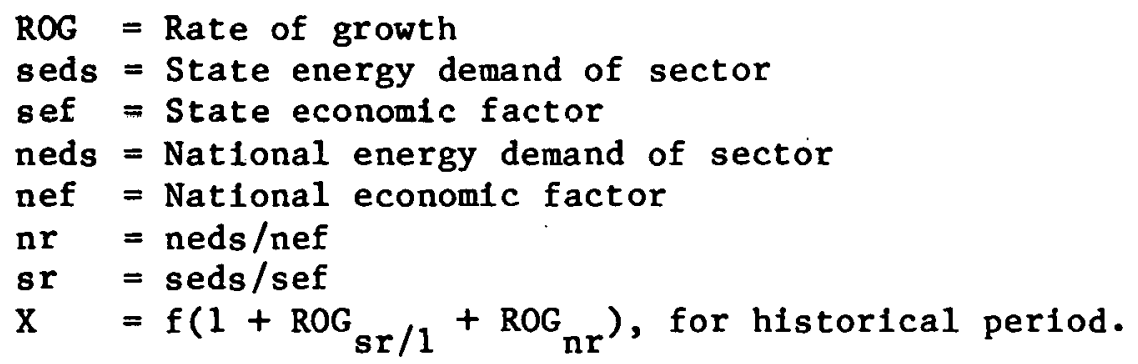


TABLE 3.5 REGIONAL CRUDE FEEDSTOCKS

(BASE CASE COMPOSITIONS)

Rocky Mountain Region

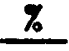

Low Sulfur Crude

High Sulfur Crude

Great Lakes Region

Local Crudes

10

North Slope

Imported Sweet

25

Imported Sour

Mid-Continent Region

Local Crudes

40

Inter-PADD Sour

15

Inter-PADD Sweet

45

$\overline{100}$ 


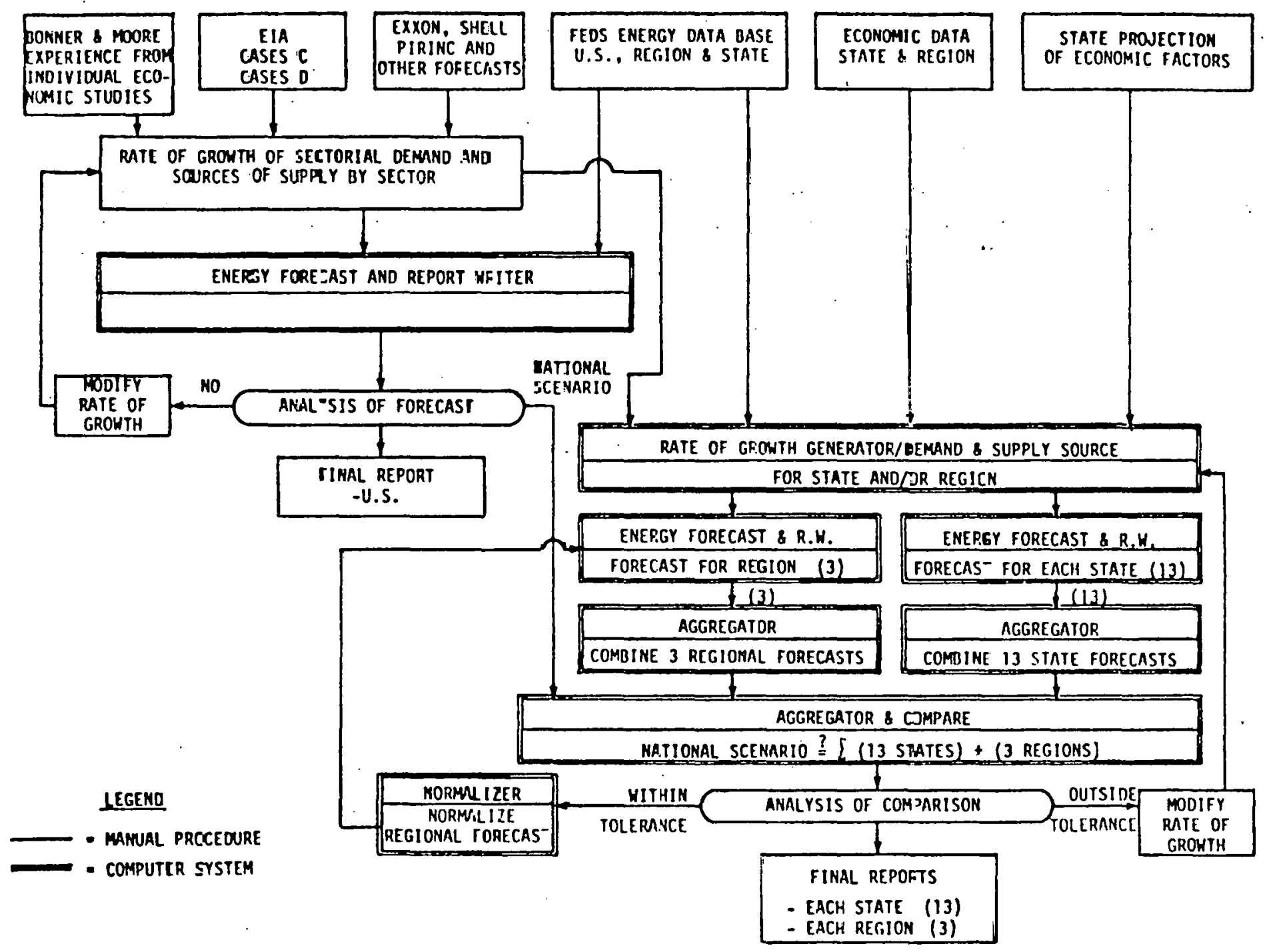

FIGURE 3.4 FLOKCHART OF ENERGY FORECAST SYSTEM 

demand.

The following shows the macroeconomic factor used for each net sector

\begin{tabular}{l}
\multicolumn{1}{c}{ Sector } \\
\hline Residential \\
Commercial \\
Transportation \\
Industrial
\end{tabular}

The power sector is developed by taking the electrical-energy supply to each sector expanded by the efficiency of generation for that state or region. The ROG of sources of supply to the power sector are based on projected capacity increases of the various types of power-generating plants. Available capacity for the various sources of electrical energy can be entered explicitly.

Data for the desired states are then summed, to produce the desired : regional energy product demand forecasts.

Regional Product Demand Forecasts. Product demand forecasts, major product classes, are shown in Table 3.6 for three reglons.

The Grsat Lakes Region is the largest consumer with 1995 demand at 4,062,296 barrels per day. The distribution of products indicates that gasoline will continue to be. the largest single product consumed. The percent of gasoline in the total product demand is forecast to drop from around $50 \%$ to $36-38 \%$ of the total. This is due to a low or negative growth in gasoline demand as shown in Table 3.6. Distillate growth in all three regions is above $2.6 \%$ per year and is reflected in distillate becoming an increasing percentage of the total product.

The Great Lakes Region contains the highest product consumption, followed by the Mid-Continent Region (which is less than half of the consumption in the Great Lakes) and the Rocky Mountain Region (under :20\% of Great Lakes). The relative product distribution shown in Table 3.6 is simllar for all three regions, the main exception being the high consumption of "." LPG in the Mid-Continent Region.

Refinery Product Demands. The refined product demands shown in Table 3.6 have been modified to produce the product demands imposed on the regional refineries. The distribution of products is shown in Table 3.7. Refinery product demands were developed by adjusting regional product demand forecasts for product imports to and exports from the regions. These imports and exports were based on historical product movements to and from the region. The gasoline pool was divided into regular unleaded (70\%'of pool) and $\vdots$. premium unleaded ( $30 \%$ of pool) grades. The distillate pool was split into No. 2 diese1 of and No. 2 fuel ofl based on the historic usage in.; each region. The residual fuel oll pool was apportioned to low sulfur : No. 6 fuel oil ( $65 \%$ of pool) and high sulfur No. 6 fuel oil ( $35 \%$ of -pool). The feedstock volume was allocated to gasoline and distillate fractions. LPG demand was not fixed, but allowed to vary depending on the refinery capability to produce LPG from the selected crude and synthetic ofl feedstocks.

The breakdown between Unleaded Regular and Unleaded Premium was based on data presented by DuPont in a paper on "Gasoline Octane Quality and 
TABLE 3.6 PRODUCT DEMAND FORECASTS

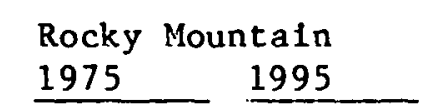

Mid-Continent

1975

TOTAL DEMAND, B/CD

$$
\text { LPG }
$$

Jet Fuel

Feeds tocks

Gasoline

Distillate

Residuals

Lubes, Wax, Asph.

Pet Coke

TOTAL

DISTRLBUTIUN, \%

LPG
Jet Fuel
Feedstocks
Gasoline
Distillale
Residuals
Lubes, Wax, Asph.
Pet Coke
TOTAL

$\begin{array}{rr}30681 & 37744 \\ 31709 & 49850 \\ 24326 & 35332 \\ 225365 & 239526 \\ 115154 & 193426 \\ 38704 & 58984 \\ 22414 & 34881 \\ 3987 & 4974 \\ 492339 & 654718\end{array}$

161601
51020
65368
636639
208582
55698
69125
20634
1268666

206594
81387
86803
633329
421299
154429
81383
25119
1690340

187918
118153
200984
1516442
662870
213745
154431
37486
3092027

255073

199761

350837

1545547

1153279

310023

199831

47945

4062296

GROWTH RATE, 1975-1995, \%/YEAR

\section{LPC}

Jet Fuel

Feeds tocks

Gasoline

Distillate

Residuals

Lubes, Wax, Asph.

Pet Coke

TOTAL

$\begin{array}{rr}6.2 & 5.8 \\ 6.4 & 7.6 \\ 4.9 & 5.4 \\ 45.8 & 36.6 \\ 23.4 & 29.5 \\ 7.9 & 9.0 \\ 4.6 & 5.3 \\ 0.8 & 0.8 \\ 100.0 & 100.0 \\ \% / \text { YEAR } & \\ & 1.04 \\ & 2.29 \\ & 1.88 \\ & 0.31 \\ & 2.63 \\ & 2.13 \\ & 2.24 \\ & 1.11 \\ & 1.44\end{array}$
12.3
4.8
5.1
37.5
24.9
9.1
4.8
1.5
100.0

$\begin{array}{rr}6.2 & 6.4 \\ 3.8 & 4.9 \\ 5.5 & 8.6 \\ 49.0 & 38.0 \\ 21.4 & 28.4 \\ 6.9 & 7.6 \\ 5.0 & 4.9 \\ 1.2 & 1.2 \\ 100.0 & 100.0\end{array}$

1.24

2.36

1.43

$-0.03$

3.58

5.23

0.82

0.99

1.45
1.54

2.66

2.82

0.10

2.81

1.88

1.30

1.24

1.37 
TABLE 3.7 PRODUCT DEMAND ON REGIONAL REFINERIES

(\% OF TOTAL PRODUCT IN BASE CASE)

Product

LPG

Regular No-Lead

Premium No-Lead

Kero Jet

No. 2 Diesel

No. 2 Fuel $0 i 1$

Low Sulfur No. 6

High Sulfur No. 6

Coke

Lubes \& Asphalt

Plant Fuel
Rocky Mount

26.1

11.2

8.1

15.1

16.8

6.6

3.6

0.8

4.7

5.9

$\overline{100.0}$
Mid-Continent $\quad$ Great Lakes

1.7

32.6

14.0

6.1

18.3

10.0

6.4

3.4

0.0

5.2

2.3

$\overline{100.0}$
2.0

27.7

11.9

5.3

14.6

20.0

4.9

2.7

2.0

6.6

2.2

$\frac{2.2}{100.0}$ 
Demand" presented at the 1979 API mid-year meeting which indicated that the current 92 RON unleaded gasoline will satisfy $85 \%$ of those vehicles requiring unleaded. Their forecasts for future consumption of two grades of unleaded gasoline show the following results:

1985 UNLEADED GASOLINE FORECASTS

$\begin{array}{cl}\text { Percent Total } & \text { Percent } \\ \text { Gasoline } & \text { Unleaded }\end{array}$

Case A

Unleaded Regular 92 RON

$62 \quad 77$

Higher Octane Unleaded 98 RON

$\frac{19}{81} \quad \frac{23}{100}$

Case B

Unleaded Regular $92 \cdot$ RON

54

Higher Oetane Unleaded 98 RON

$\frac{23}{77} \quad \frac{30}{100}$

Case $A$ assumed no further increase in octane requirements would take place beyond 1978. Case B forecasted that by 1985 the requirements of the 50th percentile vehicle would be increased by 1.5 octane numbers and the requirements of the 90 th percentile vehicle would be increased by 2.5 octane numbers above the 1975 values. The 70-30 breakdown in Case $B$ was selected for use in the study.

\section{F. Product Specifications}

The product specifications employed in building the reginnal refinery models are shown in Table 3.8. The spectfications reported for regular unleaded, premlum unleaded, and No. 2 diesel are based on Bonner \& Moore's experience in modeling refinery and product blending operations. Gasoline octane requirements and regional differences in these requirements were based on information reported by DOE. $(2,3)$

Broadcut fuel production has been included for potential use in a future fuel-tolerant engine such as a stratified charge or spark-assisted diese1. Part of the benefit of this type of engine is reported to be improved tuel economy and refinery energy savings. Qualities were defined after consideration of combustion and fuel system needs along whth storage, safety, and emissions aspects.

Specifications for the broadcut fuel are given in Table 3.9. Distillation ranges were set to incorporate distillate fuel fractions and thereby increase BTU content on a volume basis which contributes to improved fuel economy. Vapor pressure was included to permit use of gasoline components and gasoline storage faclitiles. The vapor pressure range selected should keep storage vapor space in safe condition (above the upper explosive limit) down to temperatures of $35^{\circ} \mathrm{F}$ for 5 pound RVP and $15^{\circ} \mathrm{F}$ for 9 pound RVP.(4) Sulfur and nitrogen were selected to achieve reasonable emissions.

Not all of the specifications were used in modeling broadcut fuel blending in the regional models. Those used are shown in Table 3.8 , selected 


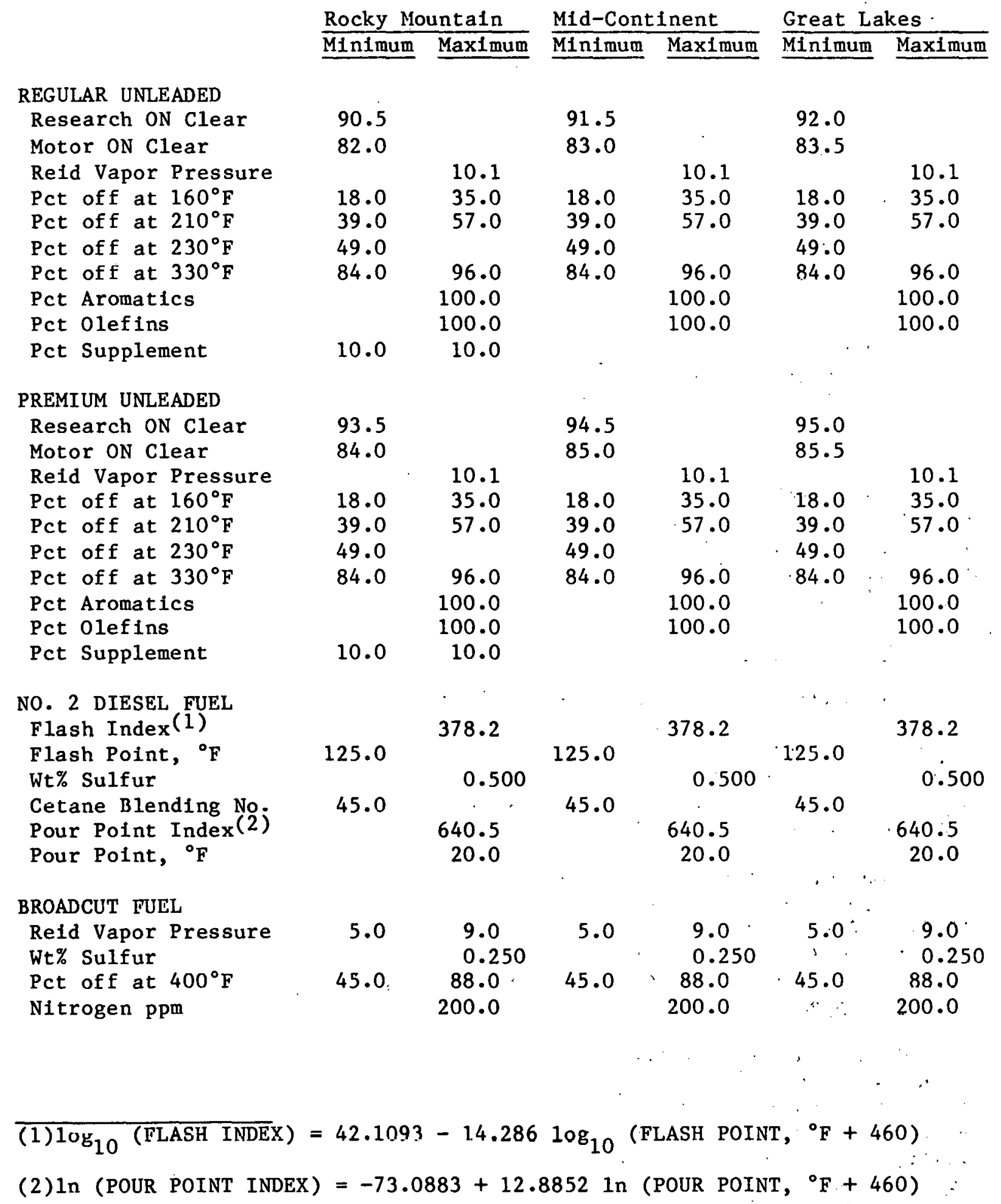




\begin{tabular}{|c|c|c|c|c|c|}
\hline & $\begin{array}{l}\text { ASTM Tes } \\
\text { Method }\end{array}$ & & Minimum & & Maximum \\
\hline $\begin{aligned} \text { Gravity, } & { }^{\circ} \text { API } \\
& \text { Specific }\end{aligned}$ & D 287 & & $\begin{array}{l}30.0 \\
0.75\end{array}$ & & $\begin{array}{l}57.0 \\
0.875\end{array}$ \\
\hline Distillation, ${ }^{\circ} \mathrm{F}$ & D 86 & & . & & -- \\
\hline $\begin{array}{l}50 \% \\
90 \%\end{array}$ & . & & $\begin{array}{l}220 \\
440\end{array}$ & & $\begin{array}{l}400 \\
640\end{array}$ \\
\hline $\begin{array}{l}\text { EP } \\
\text { Residue, vol\% }\end{array}$ & & : & -- & & $\begin{array}{ll}--- \\
1 \\
\vdots\end{array}$ \\
\hline Reid Vapor Pressure, $1 b$ & D 323, T & D 2.551. & $5 \cdot$ & & 9 \\
\hline $\begin{array}{l}\text { Aromatics, vol\% } \\
\text { Sulfur, wt } \% \\
\text { N1trogen, ppm wt }\end{array}$ & $\begin{array}{l}\text { D } 1319 \\
\text { D } 1552 \\
\text { D } 3431\end{array}$ & Note 2 & : & & $\begin{array}{l}50 \\
0.25 \\
200\end{array}$ \\
\hline $\begin{array}{l}\text { Viscosity, cSt at } 100^{\circ} \mathrm{F} \\
\text { Cloud Point, }{ }^{\circ} \mathrm{F}\end{array}$ & $\begin{array}{ll}\text { D } & 445 \\
\text { D } & 2500\end{array}$ & . & 0.5 & : & $\begin{array}{l}6.0 \\
\text { See Note } 1\end{array}$ \\
\hline $\begin{array}{l}\text { Ash, wt } \% \\
\text { Carbon Residue on } 10 \% \text { Bottoms } \\
\text { Water and Sediment, vo } 1 \%\end{array}$ & $\begin{array}{ll}\text { D } & 482 \\
\text { D } & 524 \\
\text { D } & 1796\end{array}$ & & . & & $\begin{array}{l}0.01 \\
0.35 \\
0.05\end{array}$ \\
\hline $\begin{array}{l}\text { Corrosion at } 122^{\circ} \mathrm{F} \\
\text { Oxidation Stability, mg/100 m1 }\end{array}$ & $\begin{array}{ll}\text { D } & 130 \\
\text { D } & 2274\end{array}$ & & & & $\begin{array}{l}\text { No. } 3 \\
2 . n^{3}\end{array}$ \\
\hline & & & & & \\
\hline
\end{tabular}

1. Cloud point should follow guldance in ASTM D 975 for diesel fuels, 1.e., maximum shall be $6^{\circ} \mathrm{C}$ above tenth percentile minimum temperature for season and area where used.

2. Sulfur determination allowed by cquivalent metliods. 
because of avallability of data on the component streams. The gravity of the broadcut fuel was simply reported rather than being constrained to the spectfied ranges; only one broadcut blend produced in the computer cases fell slightly outside the gravity range.

G. Additional Modeling Considerations

Forecasts for the refinery fuel products are naturally based on energy requirements to be supplied by each of the fuels. These requirements are then translated to physical volume requirements (barrels) using a standard conversion factor for each fuel product type. Normally, the conversion factor can be considered to be constant and essentially independent of processing sequence and blending operations since specifications of required physical properties on the product do not permit much variation in the heating value (expressed as BTU per barrel). This constant heating value assumption was considered doubtful for two products: low sulfur residual fuel oil and broadcut motor fuel. Depending on the type of crude oils available, the most economical way to supply the low sulfur residual fuel market involves blending significant amounts of light ofls into.the residual fuel to "dilute" or "blend off" the sulfur in the heavy residuals from crude distillation. The result is a light residual fuel ofl with a significantly lower heating value per barrel of fuel oil than has been traditional. The broadcut. fuel heating value could also vary several percentage points (depending upon its composition), since distillation and gravity specifications were broad enough to allow anywhere from twentyfive to Seventy-five percent naphtha to be included in the broadcut blend.

The forecast demands for these fuels were expressed in barrels based.. on assumed heating values as follows:

$\begin{array}{lr}\qquad \text { Fuel } & \text { Net Heating Value } \\ & 5.40 \\ \text { Low Sulfur Residual } & 5.88\end{array}$

To assure that the model produced sufficient volume of the fuels. (whatever their energy content) to satisy the forecast demand the volumes of the ". blends of low sulfur resldual and broadcut fuels were corrected to represent barrels of standard fuels with heating values as shown above. The differences between the actual barrels blended and the barrels sold were accounted for in refining loss or gain.

The actual formulation used in the model is expressed as follows:

$$
\text { Volume blended }=\sum_{1} \mathrm{v}_{1}=\mathrm{V} \text {, }
$$

where $v_{1}=$ the volume of the ith component in the blend.

$$
\text { Heating value of Mixture }=\sum v_{1} B_{1}=H \text {, }
$$

where $B_{i}$ is the heating value expressed as million BTU per barrel for component 1 .

$$
\text { Standard barrels }=\mathrm{V}_{\mathrm{s}}=\mathrm{H} / \mathrm{B}_{\mathrm{s}}
$$

where $B_{S}=s t a n d a r d$ heating value, million BTU per barrel

Loss due to conversion $=\mathrm{V}-\mathrm{V}_{\mathrm{s}}$ 
H. Model Generation - Regional Base Cases for 1995

Using the data described above, composite refinery models were generated for each of the three regions. Feedstocks to the refineries were defined based on the crude supply forecasts.

Product demands from refining also forecast for each region were scaled down to the model size used and placed as fixed demands (with one exception) on the refinery model. Since the product demand is fixed, product prices are not needed in the model since they do not influence optimization.

The exception is the demand for liquifled petroleum gas (LPG) which is primarily propane. There are no refinery processes that can efficiently convert the other parts of crude of 1 into propane. It is produced mainly as a by-product of cracking and reforming reactions. The actual availahility of LPG from a refinery is also dependent upon several factors that cannot be modeled because the refiner has little control over them. For example, small amounts of propane are found in the rrile sharge, but the propane content of crude shown in standard assays may not relate to what is actually recelved. Further, the amount of propane produced from catalytic reforming depends on feed characteristics as well as the type and history of the catalyst. It was preferable to let the LPG production from the model vary and therefore a price must be supplied for LPG production. Since the LPG produced from a refinery is malnly a by-product, the model's response is relatively independent of the price placed on the LPG as long as it bears a reasonable relation to the cost of raw material (crude).

Incremental volumes of crude required above the base level defined by 1979 volumes would be met by swing crudes selected for each region. This swing crude was assigned a price so that the refinery model could choose the volume of this crude which $1 t$ would process within the constraints of the fixed set of product demands. The swing crudes for the three regions and their prices are:

$\frac{\text { Region }}{\text { Rocky Mountains }}$
Mid-Continent
Great Lakes

$\frac{\text { Crude }}{\text { Low Sulfur }}$
High Sulfur
Inter-PADD Sweet
Imported Swcct

Price, \$/BBL

$\$ 27.00$

22.00

27.00

27.00

In the Rocky Mountains, the two crudes were held in the ratio of 1.44 bbls of low sulfur to $1.00 \mathrm{bbl}$ of high sulfur. The swing crudes were considered to be discretionary crudes (especially in the Mid-Continent and Great Lakes). The 1979 crude prices should not be regardcd as rigorous values bur only as a directional indicator of the worth of the crude relative to other crudes or products which have been allowed to vary. 
. In addition to allowing the volume of certain crudes to vary, some products and other feedstocks were allowed to vary in price relative to LPG. These were:

\begin{tabular}{l} 
Component \\
\hline LPG (product) \\
Coke (product) \\
Natural Gasoline (feed) \\
N-butane (feed) \\
Isobutane (feed)
\end{tabular}

Price, $\$ / B B L$
$\$ 20.00$
13.50 FOE BBL
28.00
21.00
22.00

The results of the base case simulations are shown in Tables 3.10 through 3.12. Table 3.10 contains the overall summary, Table 3.11 shows the processing summary, and Table 3.12 lists the product compositions.

In all three regions, the refinery model responded to the low growth in gasoline demand by not building any new catalytic cracking units. Visbreaking capacity was added in each region. The refinery model chooses to add visbreaking because it adds to the volume of middle distillate material which, as noted above, is growing at over $2.6 \%$ per year. The yield of gasoline blendstock fractions is low (about $11 \%$ on feed) which is another reason this process is attractive. The crude tower and vacuum unit increases are a natural consequence of the overall increase in demand.

The product compositions are relatively similar in the Mid-Continent and Great Lakes regions as seen in Table 3.11. The main differences are due to octane specifications on the gasolines. The Great Lakes Region gasolines are higher by 0.5 octane number which caused the octane level of the reformate to be higher on average than in the Mid-Continent.

The Rocky Mountain Region is somewhat different due to several factors. Because of altitude, the octane requirements on the gasolines are lower than in the Great Lakes and Mid-Continent, 2.0 and 1.5 numbers respectively. The cut point on the vacuun tower operation was changed from $1050^{\circ} \mathrm{F}$ to $930^{\circ} \mathrm{F}$ based on the determination that the $930^{\circ} \mathrm{F}$ cut point was representative of average historical vacuum tower operations. The $1050^{\circ} \mathrm{F}$ operation is typical of conditions achieved only in new vacuum units.

In the Rocky Mountain Region the volume of natural gasoline was set at $4200 \mathrm{~B} / \mathrm{D}$. In the other regions the model was allowed to choose the volume of natural gasoline to use based on price relative to the swing crude prices. This difference would primarily affect the gasoline composition.

The demand for petroleum coke in the Rocky Mountain region was fixed; in the other regions, it was allowed to swing based on a reasonable price relative to crude oil. Also in the Rocky Mountain Region the hydrotreated kerosene and distillate fractions from different crudes were commingled into two streams: a combined hydrotreated kerosene and a combined hydrotreated distillate. The effects of this commingling will show up in differences in the No. 2 diesel oil blend compositions. 
TABLE 3.10 REGIONAL BASE CASES FOR 1995

OVERALL SUMMARY

RAW MATERIALS B/D

Low Sulfur Crude

High Sulfur Crude

Locall Crudes

Inter-PADD Sour

Inter-PADD Sweet

North, Slope

Imported Sweet

Imported Sour

N-Butane

IsoButane

Natural Gasoline

TOTAL RAW MATERIAL̈S

PRODUCTS, B/D

LPG

Regular No-Lead

Premfum No-Lead

Broadcut Fuel

Kero Jet

No. 2 Diese1

No. 2 Fuel 011

Low Sulfur Resid

High Sulfur Resid

Coke

Lubes \& Asphalt

Plant Gas Fuel

Volume Loss

TOTAL PRODUCTS

\section{UTILITIES}

Plant Fuel, MMBTU/D

Purchased Fue1, MMBTU/D

Total Fuel, MMBTU/D

Cat/Chem $\$ / D$

Sulfur, Tons/D

NEW FACILITIES

Crude Unit

Vacuum Tower

Naphtha Hydrotreater

Cat Reformer

Kero/Gas $011 \mathrm{Htr}$

Visbreaker

Hydrocracker

Cat Cracker

Alkylation

Hydrogen, MSCF/D

Delayed Coke
Rocky Mountain

Region

Mid-Continent

Region

69925

48932

0

0

.0

0

0

1646

1386

4200

126090

1465

33400

14300

0

10400

19400

21500

8500

4600

1000

6000

7620

(2096)

126090

37968

760

38728

8221

98

19312

14759

3667

3162

21.524

1023

0

0

0

0
Great Lakes

Region

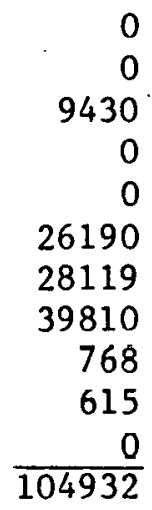

2214

29846

12791

0

5691

15702

21684

5318

2863

2106

7114

2363

(2760)

(813)

54971

8033

9980

18013

4480

9

9271

55

27742

42678

3549

11012

6210

0
1372

0

1262

0

0

0

0

0.

(

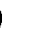

8

5

0


TABLE 3.11 REGIONAL BASE CASES FOR 1995

PROCESSING SUMMARY

\begin{tabular}{|c|c|c|c|c|}
\hline & $\begin{array}{l}\text { Rocky } \\
\text { Region }\end{array}$ & tain & $\begin{array}{l}\text { Mid-Continent } \\
\text { Region } \\
\end{array}$ & $\begin{array}{l}\text { Great Lakes } \\
\text { Reglon } \\
\end{array}$ \\
\hline 85-145 LSR Naphtha & 9488 & & 2670 & 3.069 \\
\hline \multicolumn{5}{|l|}{ GASOLINE REFORMER } \\
\hline 145-200 HTR SR Naphtha & 7377 & & 2670 & 4250 \\
\hline $\begin{array}{l}200-330 \text { HTR SR Naphtha } \\
330-400 \text { HTR SR Naphtha }\end{array}$ & 13650 & & $\begin{array}{l}6960 \\
1720\end{array}$ & 9960 \\
\hline Htr $170-375$ Hydrocrackate & 1883 & & 516 & 4259 \\
\hline Htr Visbreaker Gasoline & 81 . & & 210 & 1440 \\
\hline Htr Natural Gasoline & 391. & & & \\
\hline TOTAL FEED & $\overline{23382}$ & & $\overline{12076}$ & 20009 \\
\hline \multicolumn{5}{|l|}{ CATALYTIC CRACKER } \\
\hline $700-1050 \mathrm{Htr}$ VGO & 12285 & & & \\
\hline $700-930 \mathrm{Htr}$ VGo & & & 5115 & 16592 \\
\hline Other Gas Oils & 11777 & & 8915 & 6901 \\
\hline TOTAL FEED & 24062 & & 14030 & $\overline{23493}$ \\
\hline \multicolumn{5}{|l|}{ DELAYED COKING } \\
\hline 1050+Residue & 1067 & & 0 & \\
\hline $930+\operatorname{Res} 1 \mathrm{due}$ & & & 0 & 365 \\
\hline $970+$ Slurry & 1573 & & $\underline{0}$ & 4949. \\
\hline TOTAL FEED & 2640 & & $\overline{0}$ & $\overline{5314}$ \\
\hline \multicolumn{5}{|l|}{ KERO/DISTTILLATE HDS } \\
\hline $550-650 \mathrm{Sr}$ Distillate & 3808 & & & \\
\hline $\begin{array}{l}\text { Light Cycle oil } \\
650-700 \text { VGO }\end{array}$ & $\begin{array}{l}3724 \\
5886\end{array}$ & & 282 & 734 \\
\hline $700-1050$ VGO & 13000 & & & \\
\hline $700-930$ VGO & & & 5379 & 17447 \\
\hline TOTAL & 26418 & & $\overline{5661}$ & $\overline{18181}$ \\
\hline
\end{tabular}


TABLE 3.12 REGIONAL BASE CASES FOR 1995

PRODUCT COMPOSITIONS, VOLUME \%

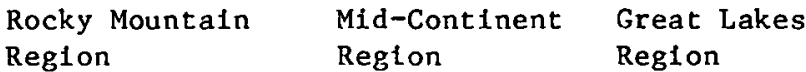

REGULAR UNLEADED

Light Straight Run

Region

REFORMATE: 100 RON

10.8

14.5

12.7

Petroleum

21.1

0

26.6

$\frac{0}{26.6}$

22.9

Synthetic

Sub-Total

REFORMATE: 90 RON

Petroleum

Synthetic

Sub-Total

C3/C4 Alkylate

Butanes

Natural Gasoline

Cat. Gasoline C5-250

Petroleum

Synthetic

Sub-Total

Cat Gasoline: $250-410$

Petroleum

Synthetic

21.1

$\frac{0}{21.1}$

5.0

$\frac{0}{22.9}$

10.0

7.0

9.9

\begin{tabular}{l}
5.0 \\
0 \\
\hline 5.0
\end{tabular}

9.3

11.8

$\frac{0}{9.3}$

7.3

11.4

7.9

6.8

0

0

$\frac{n}{6.8}$

12.7

14.8

0

$\frac{0}{14.8}$

13.3

0

22.1

21.0

$\overline{13.3}$

0

0

Sub-Total

TOTAL REGULAR

100.0

$\overline{22.1}$

$\overline{21.0}$

PREMIUM UNLEADED

Light Straight Run

REFORMATE: 100 RON

Petroleum

Synthetic

Sub-Total.

REFORMATE:

$90 \mathrm{RQN}$

Petroleum

Synthetic

Sub-Total

C3/C4 Alkylate

Butanes

Natural Gasoline

Cat. Gasoline C.5-250

Petroleum

Synthetic

Sub-Total

Cat Gasoline: $250-410$

Petroleum

Synthet Ic

Sub-Total

5.7

1.8

$11 \cdot 1$

22.3

27.2

49.7

$\frac{0}{22.3}$

$\frac{0}{27 \cdot 2}$

$\frac{0}{49.7}$

22.3

25.4

$\frac{0}{22.3}$

0

25.

12.0

11.5
0

0

9.3

0

100.0

23.9

18.5

$\frac{0}{23.9}$

$\frac{0}{1.8 .5}$

0

$\frac{0}{0}$

12.4

7.7

0

7.3

5.8

12.2

$\frac{0}{12.2}$

$\frac{0}{7.3}$

6.9

$\frac{0}{5.8}$

$\frac{0}{6.9}$

TOTAL PREMIUM

100.0

100.0

100.0

No. 2 DIESEL FUEL

Trt'd Kero 400-550

Petroleun

Synthetic

30.7

39.7

0

48.3

$\frac{0}{30.7}$

$\frac{0}{48 \cdot 5}$

Trt'd D1st 550-650

Petroleum

Synthetic

Sub-Total

62.7

$\frac{0}{62.7}$

44.6

45.9

$\frac{0}{44 \cdot 6}$

$\frac{0}{45.9}$

Trt'd Lt. Cycle 011

6.6

20.7

5.8

Hydrocracker Kero

0

0

0

TOTAL NO. 2 DIESEL

100.0

100.0

100.0 
I.

Volumes of Diesel and Broadcut Fuels

After the forecast production in each region was established as on Table 3.10 product volumes were defined for the maximum diesel fuel and broadcut fuel cases. Table 3.13 shows the highway transportation fuels for product option cases in all three regions.

Base case quantities show diesel fuel as 26.9 to $28.9 \%$ of highway fuels in 1995. This level is higher than the 10-15\% typical of 1980 production. Gasoline to distillate ratio ranges from 0.93 to 1.36 .

Part of the gasoline production was replaced by the alternate type of fuel using the following factors.

\begin{tabular}{|c|c|c|c|}
\hline$\therefore$ & Base & $\begin{array}{l}\text { Maximum } \\
\text { Diesel }\end{array}$ & Broadcut \\
\hline $\begin{array}{l}\text { a. Percent Gasoline Replaced } \\
\text { b. Relative Fuel Economy } \\
\text { c. Replacement Volume,\% (a-b) }\end{array}$ & $\begin{array}{c}0 \\
1.00\end{array}$ & $\begin{array}{r}30 \\
1.35 \\
22.22\end{array}$ & $\begin{array}{r}40 \\
1.24 \\
32.26\end{array}$ \\
\hline
\end{tabular}

The fact that total highway fuel on Table 3.13 in the maximum diesel and broadcut fuel cases is nearly identical was not planned. The plan was to adjust fuel quantities to provide constant miles of travel for the cases in each region. The factors above coincidentally produce almost the same net product differential from the base case.

Inspection of Table 3.13 shows that maximum diesel fuel volume varies from 45.8 to $47.3 \%$ of total highway fuel, and gasoline to total distillate varies from 0.54 to 0.73 ratio in those cases. Broadcut fuel ranges from 24.3 to $25.0 \%$ of highway fuels, indicating similar proportions for highway fuels in each region.

One additional comparison is useful to describe the three major fuels, as used in this study:

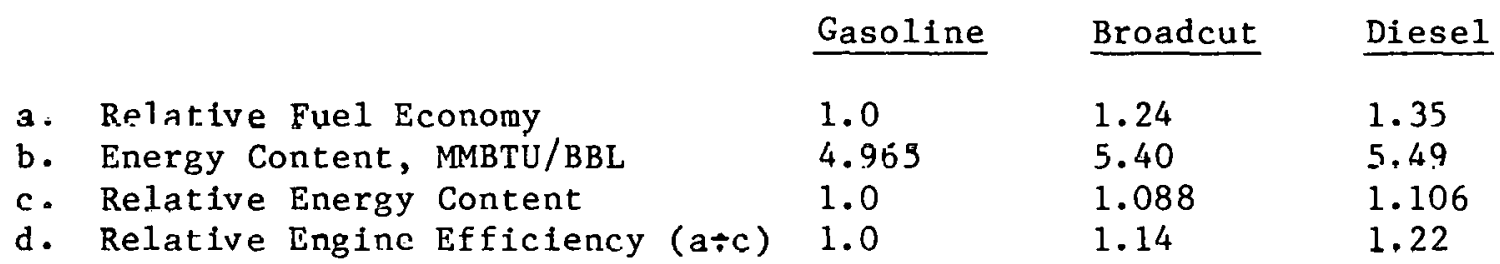

The ratios above imply that diesel engines are assumed to be $22 \%$ more efficient than spark ignition engines. The rest of the $35 \%$ diesel advantage in fuel economy results from higher energy content per volume of fuel.

Broadcut fuel engines are in between with $14 \%$ higher efficiency and $24 \%$ better fuel economy. It was planned to use $5.04 \mathrm{MMBTU} / \mathrm{BDL}$ as cnergy content of broadcut fuel and 1.22 relative engine efficiency, the same as diesel. However, the value of $5.40 \mathrm{MMBTU} / \mathrm{BBL}$ was entered instead. The net effect should be zero if the difference is applied to engine efficiency which is unknown at present, because broadcut fuel volume was adjusted to meet a given BTU demand as explained in Section III-C, Additional Modeling Considerations. The error will be correcled in future case runs. 
TABLE 3.13. PRODUCT VOLUMES FOR MAXIMUM DIESEL AND BROADCUT FUELS

Rocky Mountains

Gasoliné

Broadcut Fuel

Diesel Fuel

Total Highway Fuel

Other Distillate

fasn/nist Ratio

Mid-Continent

Gasoline

Broadcut Fuel

Diesel Fuel

Total Highway Fuel

Other Distillate

Gaso/Dist Ratio

Great Lakes

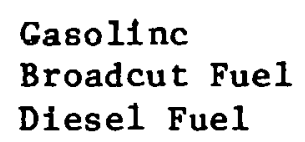

Total Highway Fuel

other Distillate

Gaso/D1st Rat1o

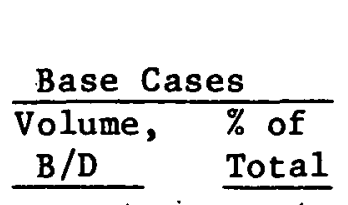

Maximum Diesel

Broadcut Fuel

\begin{tabular}{ll}
\multicolumn{2}{c}{ Cases } \\
Volume, \\
B/D of \\
\hline
\end{tabular}

$\frac{\text { Cases : }}{\text { Volume, \% of }}$

B/D : Total

$$
\begin{aligned}
& 47,700^{\circ}: 71.1 \quad 33,400: 52.7 \quad 28,600 \quad 45.1
\end{aligned}
$$

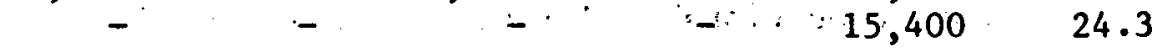

$$
\begin{aligned}
& \frac{19,400}{67,100} \quad \frac{28.9}{100 \cdot 0} \cdot \frac{30,000}{67,400} \cdot \frac{47.3}{100.0} \cdot \frac{19,400}{63,400} \quad \frac{30.6}{100.0} \\
& 31,900^{\circ} \quad 31,900 \quad 31,900 \\
& 0.93 \quad 0.54
\end{aligned}
$$

$\begin{array}{rrrrrr}25,979 & 71.8 & 18,185 & 53.2 & 15,587 & 45.6 \\ - & - & - & - & 8,376 & 24.5 \\ \frac{10,220}{36,199} & \frac{28.2}{100.0} & \frac{15,987}{34,172} & \frac{46.8}{100.0} & \frac{10,220}{34,183} & \frac{29.9}{100.0} \\ 8,938 & & & & 8,938 & \\ 1.36 & & 8,938 & & - & \end{array}$

$\begin{array}{llllll}42,637 & 73.1 & 29,844 & 54.2 & 25,564 & 46.5\end{array}$

- $\quad 13,766 \quad 25.0$

$\frac{15,702}{58,339} \quad \frac{26.9}{100.0} \quad \frac{25,183}{55,027} \quad \frac{45.8}{100.0} \quad \frac{15,702}{55,032} \quad \frac{28.5}{100.0}$

27,375

0.99

27,375

0.57

27,375 
1. "Annual Refining Report", The 011 and Gas Journal, March 26, 1979, pp. 79-156.

2. Motor Gasolines, Winter 1978-1979, Ella Mae Shelton, July 1979, Bartlesville Energy Technology Center.

3. Motor Gasolines, Summer 1978, E1la Mae Shelton, February 1979, Bartlesville Energy Technology Center.

4. Kant, F.H., Cunningham, A.R., and Farrier, M.H., "Effects of Changing the Proportions of Automotive Distillate and Gasoline Produced by Petroleum Refining," Exxon Research and Engineering Co., PB-236 900. Envi ronmental Protection Agency, EPA-460/3-74-018, July 1974. 


\section{A. Syncrude Process Selection Criteria}

In defining the refinery feedstocks for the alternative fuels study it was necessary to select candidate syncrudes from a number of processes which convert oil shale and coal to liquid materlals. The following criteria were used as the most important factors in the selection:

1. Economic viability of process

2. Current status of process development and published data

3. Availability of refinery feedstocks from the process

The goal in this evaluation was not selection of the "best" process but rather the process which wao representative of pocentialiy available future syncrude. Although data from specifir. processes werc cmployed, the processes were constdered as generic types. Syncrude converston processes and their generic groups are shown in Table 4.1 .

Oil Shale Processes

Surface retorting of oil shale has many variations, most of which are likely to be commercialized when the proper circumstances prevail. The Paraho process was used in model construction for the following reasons:

1. There is a considerable amount of publicly available data, not only on the shale oil but on refinery processing to finished products. (1)

2. Pilot scale nperatinns have been conducted and plans for commercial produrtion announced.

3. Raw shale oils produced by other retort designs show similar processing results, and thus Paraho can be used as a representative shale oil in the model.

4. The process is intended to produce a refinery feedstock. The indirect operating mode was chosen because it produces a lower pour point oll which will be easier to transport.

In situ retorting of ofl shale without removal from the ground also has variations. Fortunately, the shale oils produced are similar in most quality parameters. The Occidental process was user as the examplc for this generic type for reasons similar to the surface retort example above, plus adequate intormation was available on processing (2) for reasonably complete modeling.

Coal Liquefaction

Processes were examined for each of five major generic types of coal liquefaction considering the criteria listed above. Three process types were selected for use in the study; two others were set aside as discussed below. 
TABLE 4.1 SYNCRUDE CONVERSION PROCESSES

Generic Process

Shale 0ils

Coal 011s
Examples

Paraho, Superior

Tosco, Union

Occidental, Geokinetics, Rio Blanco

Coed, Toscoal,

Garrett, Clean-Coke

H-Coal, Exxon Donor

Solvent, Syntholl
Hydrogenation

Catalytic
SRC-II

Hydrogenation, Non-Catalytic

5. 
Pyrolysis processes have several candidates including four examples in Table 4.1. Only COED (Char O11 Energy Development) has been run with a varlety of coals and made enough data available to be used as a representative process.

Solvent extraction has undergone considerable investigation. However, it has recently been combined with direct hydrogen usage and apparently major activity has been directed toward this combined approach. For this reason, pure extraction was eliminated as a candidate process.

Non-Catalytic hydrogenation is represented mainly in the SRC-II process which is covered by published information on properties and processing. (3)

Catalytic Hydrogenation research is proceeding on several variations of the process and equipment. More data were available on the H-Coal process and refinery processing which were used in model construction.

Indirect liquefaction involves coal gasification as the first step followed by conversion to liquid process and subsequent refining. Sasol Limited does this commercially in South Africa and recently constructed and started a second, larger plant. It appeared that this process would carry out conversion and processing to finished products in one integrated operation and.not make syncrude available for other refineries.

\section{B. Syncrude Processing}

The necessary refinery processing of the syncrude charges and fractions as well as processing options allowed were defined after reviewing the results of several research studies carried out on either bench scale or pllot plant equipment.

1. Both retort and in-situ produced shale ofls must be hydrotreated before conventional crude distillation. No distinction was made becween these two syncrudes once they passed this Initial hydrotreat stage.

2. The high nftrogen content of the shale oils (even after whole oil hydrogen pre-treat) is such that further hydrogen treatment is necessary before large concentrations of the distillates can be blended to distillate fuels or can serve as hydro-cracker or catalytic cracker feed. Furthermore, the naphtha fraction must be deeply hydrotreated for essentlally complete' nitrogen removal to protect reforming catalysts.

3. Only a wide boiling naphtha was taken from the distillation operation and the downstream processing of the naphtha was restricted to (a) hydrotreating followed by catalytic reforming or (b) blending into the Broadcut Fuel. (The standard RPMS crude distillation model yielded 1ight, medium and heavy naphtha streams. Data regarding reforming the syncrude naphtha was avallable only for the wide bolling naphtha).

4. The gas ofl streams from all syncrudes were not allowed to be blended into residual fuel oils. These were hydrotreated and 
either hydrocracked or catalytically cracked to lighter products. (However, the entire atmospheric distillation bottoms stream was permitted to go to residual fuel blending.)

5. The light distillate streams (kerosene and heating ofl or diesel) were hydrotreated. These streams could be blended without hydrotreating into the broadcut fuel. The hydrotreated streams could then be blended into the light distillate products or hydrocracked or catalytically cracked. Naphtha from hydrocracking was not allowed to be blended directly into gasoline. It was first processed through a catalytic reformer. (Hydrocrackate from syncrudes was judged to be an exceptionally good reformer feed based on data avallable.)

6. Coal-derived syncrudes from three classes of processes were represented in the model. Pyrolysis derived liquids or liquids from catalytic hydrogen donor processes were judged to be of about equal in quality relative to hydrogen content and other important attributes. (This assumed the pyrolysis product was hydrotreated at the pyrolysis site.) Liquids from non-catalytic hydrogen donor processes were judged to be deficient in hydrogen content relative to the other two classes and were forced to be hydrogen treated prior to the distillation step.

7. Downstream, the coal derived streams were subjected to the same processing alternatives and restrictions as described for shale derived syncrudes. Quality differences between the shale and coal syncrudes were recognized in the downstream processes.

This processing scheme for the syncrudes should not be taken to imply that these steps will be necessary in all cases or that other processing sequences will not be found to be economical. The processing costs represented by this refining scheme will generally be comparable with other viable schemes and the subsequent processing in the model (hydrocracking and catalytic cracking) provides the necessary alternatives to estimate the ultimate allocation of the components derived from syncrude charge stocks among the refinery product pools: gasoline, kerosene, jet fuel, diesel fuel, heating oil, broadcut motor fuel, and residual fuel.

Restricting the gas oil cuts from residual fuel blending is somewhat arbitrary but justifiable. Residual fuels are usually used in large industrial furnaces or power plants and this type of application could also receive its energy requirements directly from coal. It would seem wasteful, therefore, to use a more valuable product in such applications. The option could have been left up to the model, but removing it simplified the model and reduced computing and analysis costs.

Two particular options that have been investigated elsewhere and not included in our model deserve some attention:

1. Shale oil can be charged directly to a coker and the liquid products from the coker then processed through standard refinery equipment. The limited market for petroleum coke in the areaswhere shale oil will be avallable would indicate that this route 
will be used only to a limited extent. The highly aromatic nature of syncrudes derived from coal makes this option even less attractive. Additionally, coker products from syncrudes tend to retain the nitrogen present in the charge stock, so the need for subsequent hydrogen treat for nitrogen removal would still exist.

2. The highly aromatic nature of the coal syncrudes can be exploited as suggested by UOP. By hydrocracking in two stages in series with selective catalysts in both stages, a naphtha hydrocrackate that preserves many of the original aromatic rings can be produced. The resulting naphtha has a good octane rating relative to other hydrocrackates and is also an exceptionally good feed for catalytic reforming. It was decided not to represent this particular hydrocracking route since it would complicate the model without having major effect on the overall processing cost or gasoline blend compositions.

\section{Stream Sogregation}

Une aspect of using a linear program for refinery modeling that must be given careful attention is called the "pooling problem". The problem arises because a refinery charging crudes or streams from different processes, at points ahead of the final disposition of the mixed stream. A non-linearity is therefore introduced into the model. The analyst who sets up the model must use his judgment based on experience with actual refinery operations to decide where in the processing sequence the detailed identities of the streams are to be lost. Further, in generating the model, he must assume proportions among the streams being mixed together in order for the attributes of the mixed stream to be estimated. As a result, the model cannot fully account for the pooling effert where the assumed proportiono are not realized in the problem solution. Forcing the model to match the proportions assumed leads to an overly constrained mode1. The alternative of assuming no commingling or pooling of streams results in a model with too much flexibility.

The problem associated with stream pooling can be partially overcome by recursively solving and modifying the model; the proportions determined from a "solution" are used to recalculate the mixed stream's attributes, the model is revised accordingly and solved again. This technique was used to adjust the sulfur content of the mixed streams.

For the Rocky Mountain regional model, the most significant points of stream pooling or segregation can be generally defined as follows:

1. Ahead of crude distillation, four feed pools were recognized:

Low Sulfur crudes

High Sulfur crudes

Coal-derived syncrudes

Shale-derived syncrudes

2. The naphtha fractions immediately downstream of the crude unit are:

Naphtha from crude oils Naphtha from shale syncrudes Naphtha from coal syncrudes 
3. Middle distillates, heavy gas oils, vacuum residues and atmospheric residues retained the segregation pattern shown for the crude distillation charge.

4. Products from processes after the crude distillation unit were not assumed to be segregated by feed type except for products from catalytic cracking where the products yielded from hydrotreated feeds, were kept separate from those yielded from non-hydrotreated feeds.

This pattern of pooling was selected since it has proved to be adequate in many previous refining industry studies. The primary emphas is is on segregating streams according to sulfur content. Segregation between natural and syncrude. fractions immediately downstream of the crude distillation unit is necessary because of the dramatic differences in aromatics and nitrogen contents which affect yields from and costs of the processes immediately downstream of the crude distillation unit.

The processing options for shale oil and coal oil are summarized graphically in Figure 4.1 for shale oil and Figure 4.2 for coal ofl. The flow diagrams show the processing options allowed in the model. Syncrude fractions are segregated through the process steps described on the diagram. In any processing units downstream of those shown, syncrude fractions are commingled.

Modifications Following the Rocky Mountain Region Cases

The solutions from the Rocky Mountain Model cases were carefully reviewed to see if some improvements were possible and practical before developing the models for the other regions. This analysis revealed that the wide discrepancy in aromatics levels between coal derived syncrudes and natural crudes is probably sufficient to cause refiners to maintain segregated streams beyond the hydrotreating processes for middle distillate cuts. The clue to this need was an observed difficulty in the model in meeting cetane number on diesel fuels and smoke point on jet fuels. In. fact, it was necessary to adjust the smoke point and cetane blending value of hydrotreated products to reflect some "prime component" avallability from the pool of hydrotreated stocks in order to achieve solutions to cases where the diesel fuel was being maximized. Subsequent models were generated assuming additional segregation through the hydrotreating of the $400^{\circ}-550^{\circ} \mathrm{F}$ and $550^{\circ}-650^{\circ} \mathrm{F}$ streams.

The necessary data were lacking to model one other feature that appears to be important to refinerles processing syncrudes along with natural crudes. It is not currently possible to model various severities of hydrogen treatment for the removal of nitrogen and the saturation of aromatic compounds and the extent to which these treatment effects can be kept independent. Availability of data at intermediate severities in the future would allow investigation of producing fuels at intermediate quality levels less than current specifications.

D. Syncrude Assay Data

Forecasts of costs for syncrudes relative to crude olls in the literature 


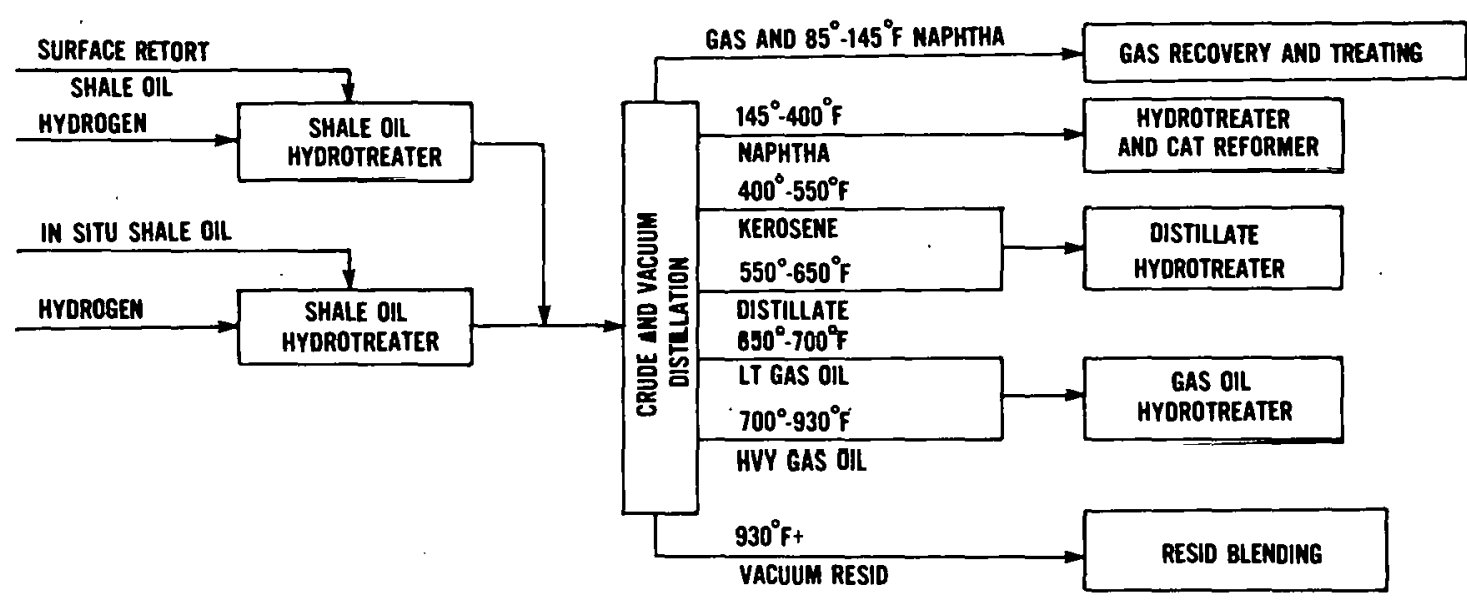

FIGURE 4.1 PROCESSTING OPTIONS - SHALE OILS

PYROLYSIS LIQUID

\section{CATALYTIC HYOROGEMATIDY}

NON-CATALYTC HYDROGENATION

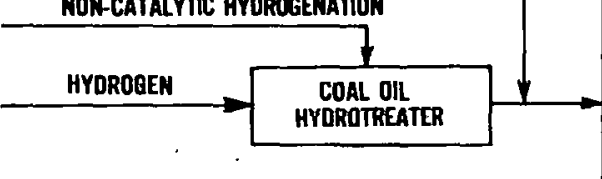

GAS AND $85^{\circ}-145^{\circ} \mathrm{F}$ NAPHTHA

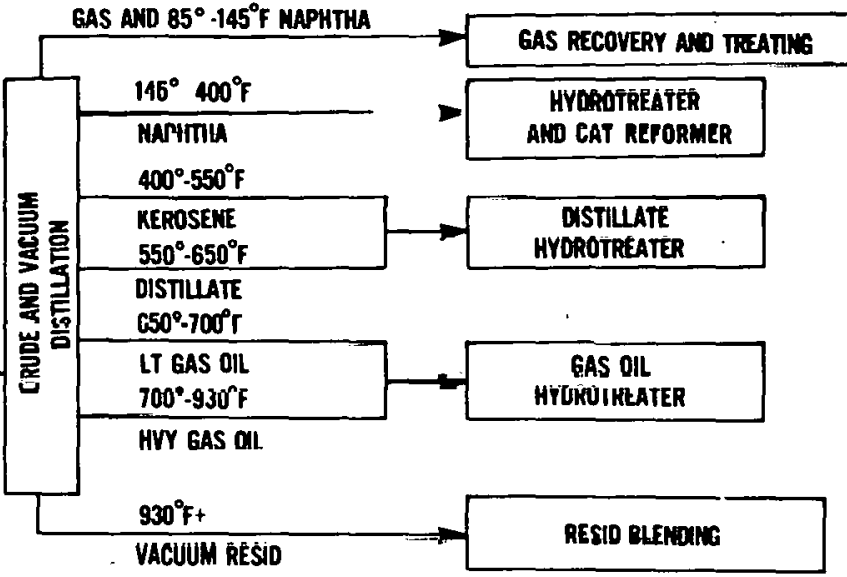

FIGURE 4.2 PROCESSING OPTIONS - COAL OILS 
show a wide range that precluded allowing the model to choose between syncrude and crude oll. It was elected to estimate the avallability of syncrude to the refining industry and to assume that the cost would allow the industry to use it in combination with natural crude. Since syncrudes tend to be light and low sulfur, it was assumed that the syncrudes would back out the light, low sulfur crude oil from the refinery charge. This swing crude would then be avallable to other regions.

The attributes of the syncrudes were estimated from recent reports that have investigated the make-up of syncrudes and the effects of subjecting them to conventional and unconventional refining processes. The Syncrude assay data used as input to this refinery model are shown in Table 4.2. Syncrude distillations are plotted on Figures 4.3 through 4.5 . These data were developed from a variety of sources which are described below.

Shale 0il Processing

1. The raw Paraho shale oll data were obtained from an assay developed for work done in "Identification of Probable Automotive Fuels Composition: 1985-2000", February 1978, page 109. This information has been modified by changing the sulfur distribution based work done at Gulf Sclence and Technology Company ("Shale 0il: An Acceptable Refinery Syncrude", H. C. Stauffer and S. J. Yanik)

2. The yields and gravities for the hydrotreated Paraho shale ofl are based on information contained in "Converting Green River Shale Oil to Transportation Fuels," R. F. Sullivan and B. E. Stangeland, Chevron Research Co., April 1978. The sulfur distributtons are based on the raw shale oll and the degree of desulfurization is based on the whole crude properties of raw and hydrotreated shale ot 1. The lighter fractions were considered to be essentlally $100 \%$ desulfurized.

3. The fraction properties for the raw Paraho shale oil are from the assay developed for "Identification of Probable Automotive Fuels Composition: 1985-2000". The properties for the hydrotreated fractions were obtained by using engineering judgment applied to data from the following sources:

- "Converting Green River Shale Oil to Transportation Fuels," R. F. Sullivan and B. E. Stangeland, Chevron Research Co., Eleventh nil Shale Symposlum Proceedings, April 1978.

- "Composition of Shale 011 and Shale 0il Derived Fuel," E. T. Robinson, Conference on Composition of Transportation Synfuels, San Antonio, Texas, October 1978.

- "Refining of Paraho Shale Oil into Military. Specification Fuels," E. T. Robinson, AlMt Meet1ng, February 1979.

- "Refining Shale Dil," R. F. Sullivan, B. E. Stangeland, and H. A. Frumkin, Chevron Research Company and C. W. Samue1, Chevron, U.S.A., API Midyear Meeting, May 1978. 
TABLE 4.2 SYNCRUDE ASSAY DATA USED IN REFINERY MDDELS

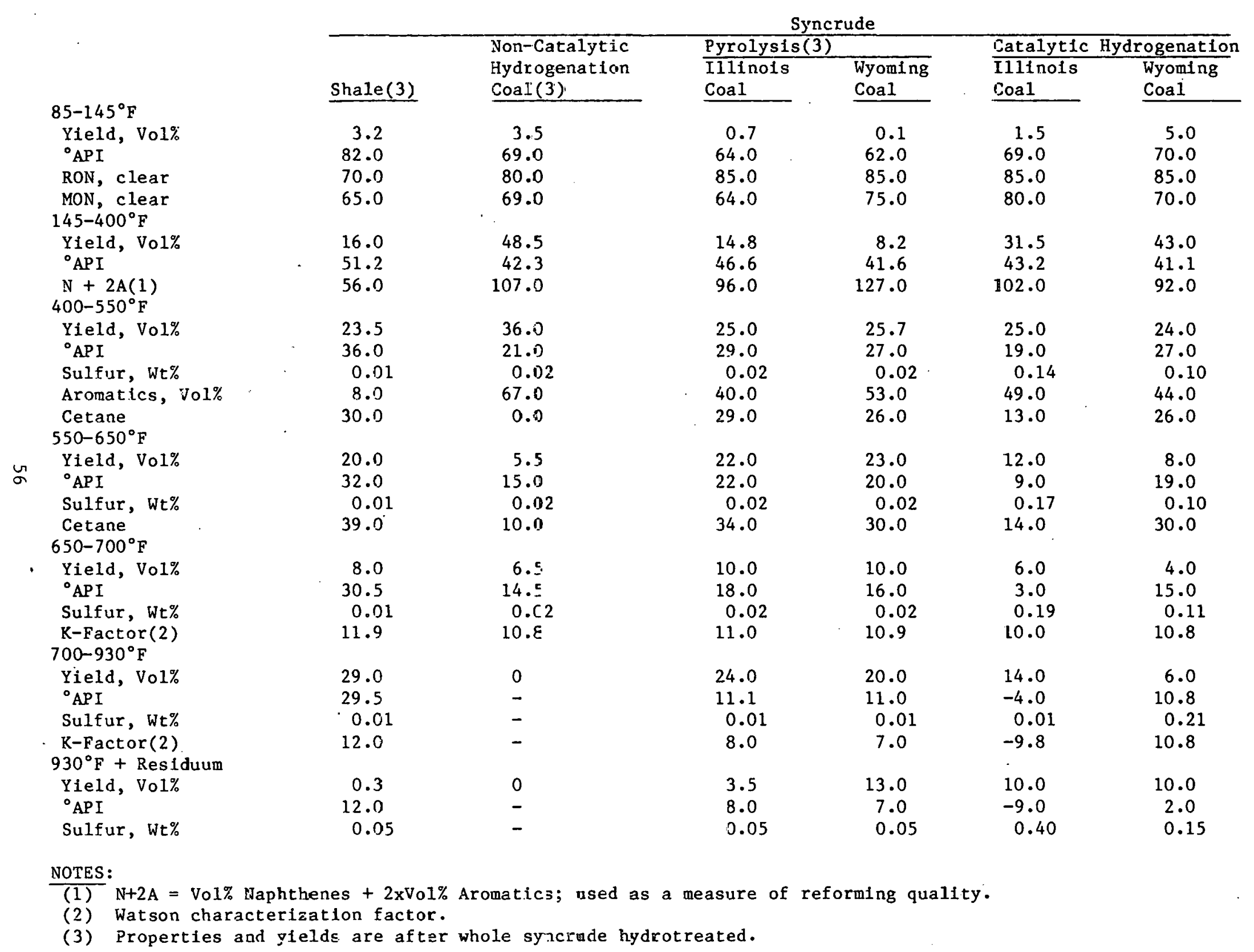




\section{FIG. 4.3 SYNTHETIC CRUDE DISTILLATION}

HYDROTREATED SHALE AND COAL OILS

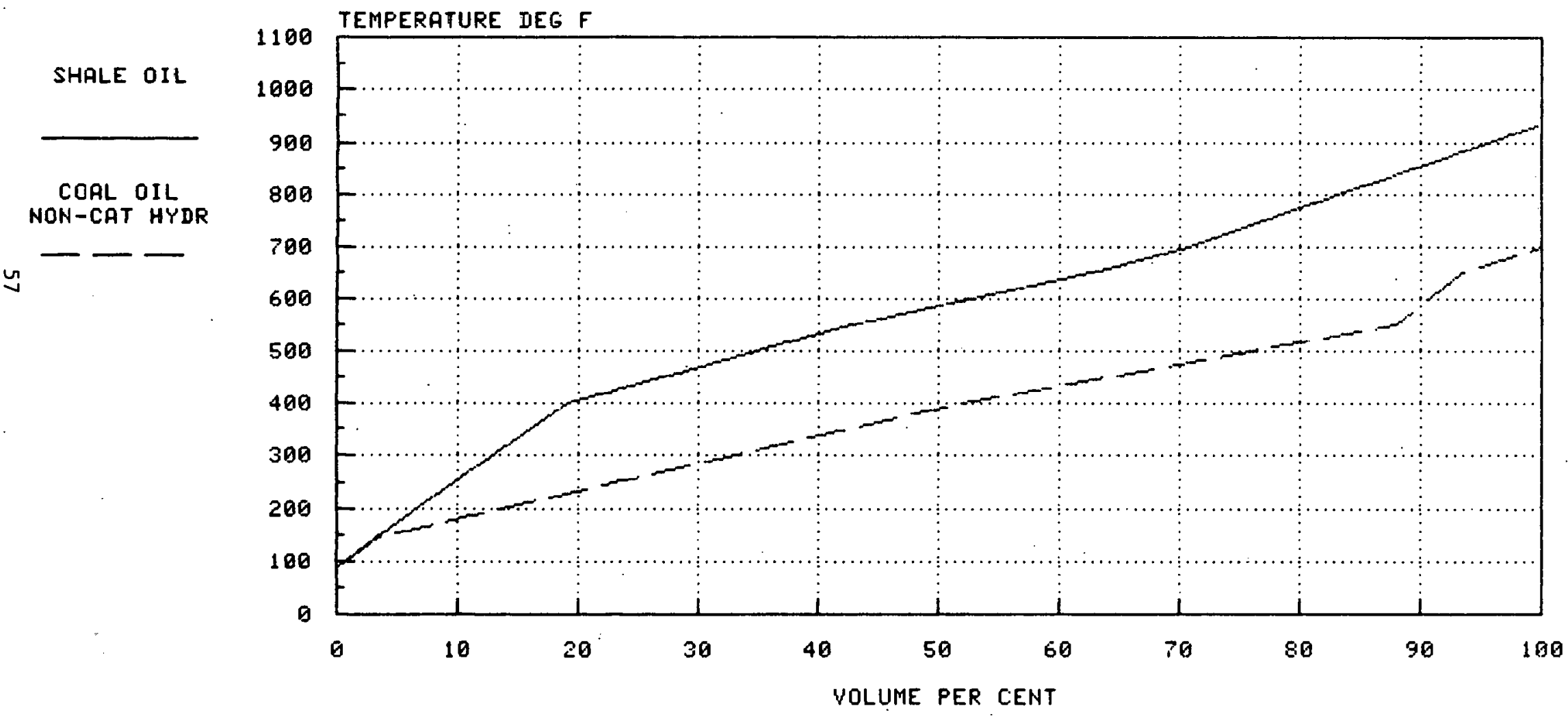


FIE. 4.4 SYNTHETIC CRUDE DISTILLATION CORL OILS FROM ILLINOIS COAL

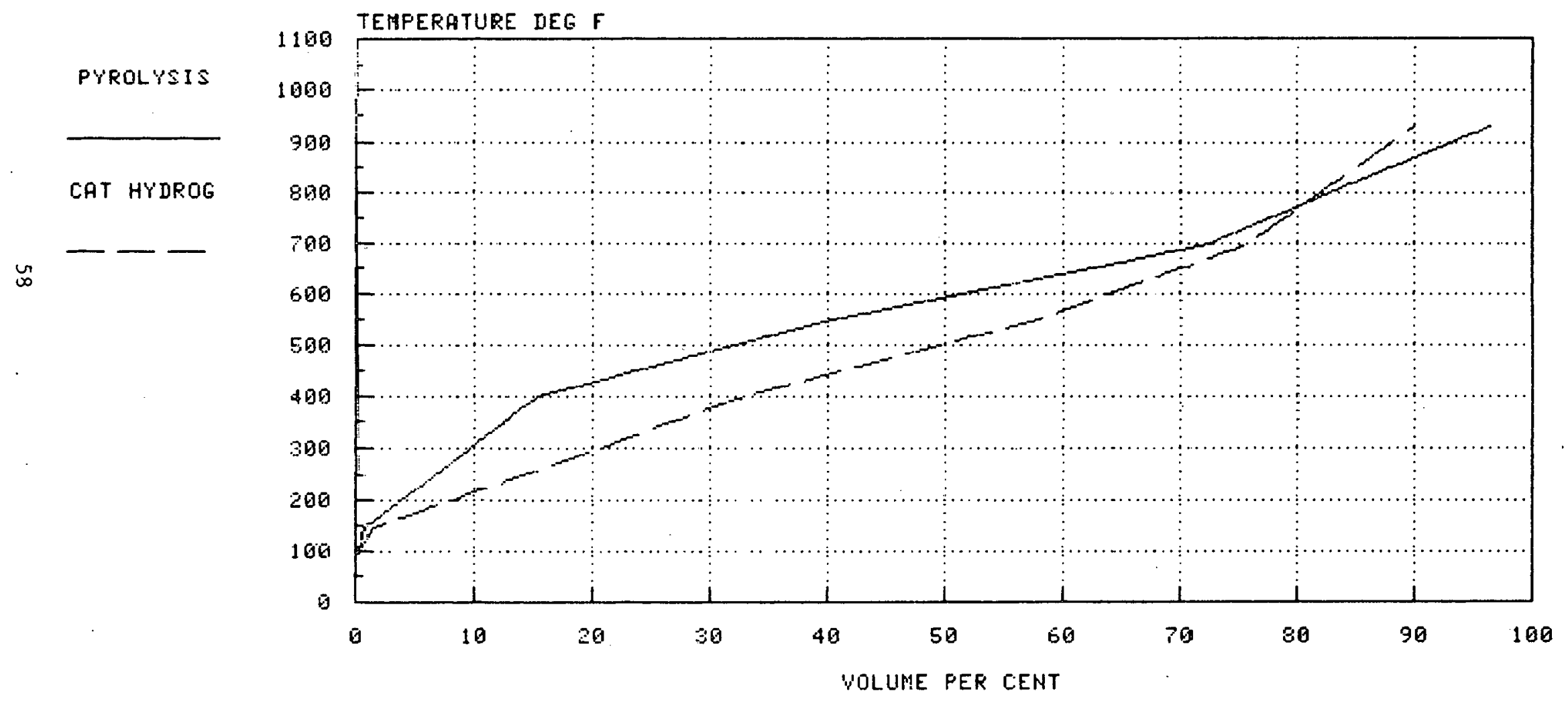




\section{FIG 4.5 SYNTHETIC CRUDE IISTILLATION}

COAL OILS FROM WYOMING CORL

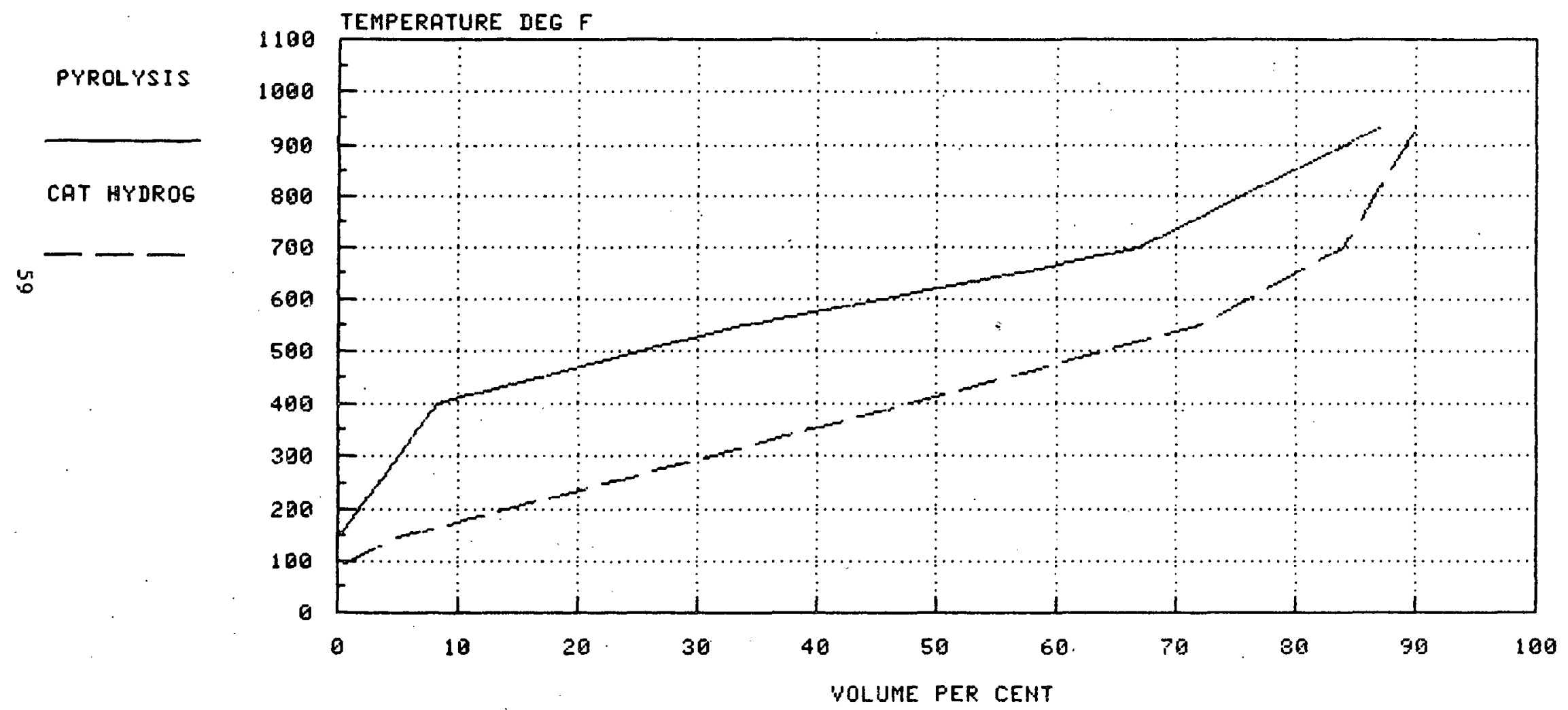


- "Shale 0il: An Acceptable Refinery Syncrude," H. C. Stouffer and S. J. Yanik, Gulf Science and Technology, September 1978, American Chemical Society National Meeting

4. The raw in-situ shale ofl data was obtained from an assay developed for work done in "Identification of Probable Automotive Fuels Composition: 19852000," February 1978, p. 109.

5. The properlies for the hydrotreated fractions were obtained by applying adjustments to data from the following sources:

- "Fleleflulng Irue Ln-situ Shale Oil," Philip L. Cottingham, U. S. DOE, Laramie Energy Research Center, October 1978, The 13th Intersociety Energy Conversion Engineering Conference, SAE.

- "Distribution of Nitrogen in Hydrocracked In-Situ Shale 011," Philip L. Cottingham, Ind. Eng. Chem. Prod. Res. Dev - Vol. 15, No. 3, 1976.

- "High Severity Hydrotreating of Shale 0.11," Philip L. Cottinghan, Laramie Energy Technology Center

- "Production of Synthetic Crude From Crude Shale 011 Produced by InSitu Combustion Retorting," C. M. Frost, R. E. Poulson, and H. B. Jensen, Laramie Energy Research Center, U. S. Department of the Interior, Bureau of Mines, Laramie, Wyoming

6. Information on hydrotreating whole shale oil was obtained from the following sources:

- "Composition of Shale 011 and Shale Oil Derived Fuel," E. T. Robinson, Conference on Composition of Transportation Synfuels, San Antonio, Texas, October 1978

- "Prerefining True In-Situ Shale 011," Phillp L. Cottingham, U. S. DOE, Laramie Fnergy Research Center, Ocluber 1978, 13th Intersociety Energy Conversion Engineering Conference

- "Converting Green River Shale 011 to Transportation Fuels," R.. F. Sullivan and B. E. Stangeland, Chevron Research Company, Apri1 12-14, 1978, Eleventh oil Shale Sympnsium Procecdings.

7. Inforwation on naphtha pretreating and reforming was obtained from the following sources:

- "Composition of Shale 011 and Shale 011 Derived Fuel," S. Kumar Kunchal, SOHIO Natural Resources Company, Presented at the Conference on Composition of Traneportation Synfuels in San Antonio, Texas, 11-13 October, 1978.

- "Shale 011: An Acceptable Refinery Syncrude," H. C. Stouffer and S. J. Yanik, Gulf Sclence and Technology Company 
8. Information on catalytic cracking was obtained from:

- "Shale 011: An Acceptable Refinery Syncrude," H. C. Stouffer and S. J. Yanik, Gulf Science and Technology Company

- "Refining Shale 0il," R. F. Sullivan, B. E. Stangeland, and H. A. Frumkin, Chevron Research Company, Richmond, CA, and C. W. Samue1, Chevron, U.S.A., Salt Lake City, UT.

- "Converting Green River Shale 0il to Transportation Fuels," R. F. Sullivan and B. E. Stangeland, Chevron Research Company, Presented at the Eleventh Oil Shale Symposium Proceedings.

9. Information on distillate hydrotreating was found in:

- "Production of Synthetic Crude from Crude Shale 0il Produced by In-Situ Combustion Retorting," C. M. Frost, R. E. Poulson, and $\mathrm{H}$. B. Jensen, Laramie Energy Research Center

- "Shale 0il: An Acceptable Refinery Syncrude," H. C. Stouffer and S. J. Yanik, Gulf Science and Technology Company

10. Hydrocracking data were obtained from:

- "Converting Green River Shale $0 i l$ to Transportation Fuels," R. F. Sullivan and B. E. Stangeland, Chevron Research Company, Presented at the Eleventh 011 Shale Symposium Proceedings

- "Refining Shale 01l," R. F. Sullivan, B. E. Stangeland, and H. A. Frumkin, Chevron Research Company, Richmond, CA and C. W. Samuel, Chevron U.S.A., Salt Lake City, UT, May 10,1978

\section{Coal Oil Processing}

1. The COED and H-Coal data were obtalned from assays developed for work done in "Identification of Probable Automotive Fuels Composition 1985-2000," February 1978, pp 112-113.

2. The ylelds and inspections for hydrotreated SRC-II oil were obtained from "Refining the Products from the SRC Coal Liquefaction Process," R. F. Sullivan, B. E. Stangeland, H. A. Frumkin, Chevron Research, 44th Refining Midyear Meeting, May 1979 and from "Refining and Upgrading of Synfuels from Coal and 011 Shales by Advanced Catalytic Processes," January 1979, R. F. Sullivan, prepared for U. S. DOE.

3. Information on fuel ofl hydrotreating for the SRC-II coal oil process was obtalned from:

- "Refining of SRC-I and SRC-II, DOE Contract EF-76-C-012315, Richard F. Sullivan, Bruce E. Stangeland, and Harry A. Frumkin 
4. Data on reforming of coal oils (specifically H-Coal) was obtained from:

- "Upgrade Coal Derived Distillates," Armand J. de Rosset, Gim Tan, and Lee Hilfman, UOP Inc., Des Plaines, Ill., May 1977, Hydrocarbon Processing, pp. 151-153.

- "Upgrading of Coal Liquids-Interim Report, Hydrotreating and Reforming H-Coal Process Derived Naphthas," Gim Tan and Armand J. de Rosset, March 1978.

5. Hydrotreating data on naphtha and middle distillates was obtained from :

- "Upgrading of Coal Liquids--Inlerlin Reporc, Hydrotreating and Fluid Catalytic Cracking of H-Coal Derived Gas Oils," Gim Tan and Armand J. de Rosset, August 1978

- "Refining and Upgrading of Synfuels from Coal and 0il Shales by Advanced Catalytic Processes," R. F. Sullivan, Chevron Research Company, April 1979

6. Fluid catalytic cracking yields were obtained from the following sources:

- "Upgrade Coal Derived Distillates," Armand J. de Rosset, Gim Tan and Lee Hilfman, UOP Inc., Des Plaines, I11., May 1977, Hydrocarbon Processing, pp. 131-137

- "lTgrading of Cool Liquids Inlerlul Report - Hydrotreating and Fluid Catalytic Ciacklug of H-Coal Derived Gas Oils," Gim Tan and Armand J. de Rosset, August 1978.

7. Hydrocracking yields were obtained from:

- "Upgrade Coal Derived Distillates," Armand J. de Rosset, Gim Tan and Lee Hilfman, UOP Inc., Des Plaines, I11., May 1977, Hydrocarbon Processing, pp. 151-153

- "Upgrading of Coal Liquids-Interim Report, Hydrucrack1ng of H-Coal. Prnress Derived Cao Oil3," Giu Tdu dul Armand J. de Rosset, November 1978

RPMS correlations were used as a basis in interpreting how coal of.s and shale oils would be refined. The above data references were consulted to make adjustments and corrections in the RPMS equations to more accurately reflect conditions surrounding the processing of syncrudes. 
V. GASOLINE SUPPLEMENTS

Four components included in the project for evaluation as motor gasoline supplements were:

Methanol

Ethanol

MTBE (methy1-tertiary-buty 1 ether)

Synthetic naphtha from methanol

Each of these components was blended into the two grades of unleaded gasoline at a concentration of 10 volume percent. This concentration was selected because it is a reasonable level for all four components in order to compare results on a consistent basis. It is also the current minimum amount of ethanol used in gasohol to qualify for tax incentives now expected to continue through 1992. At present, methanol is not authorized by EPA for use in gasoline at any concentration, except in blend with tertiary butyl alcohol (TBA). MTBE is authorized by EPA to be used up to 7 volume percent. It is assumed that these limits could be extended to 10 percent by 1995. There are no regulatory or arbitrary. limits on synthetic naphtha because it is all hydrocarbons and is essentially finished gasoline quality.

The main objective of the study was to evaluate the effect on fuel quality and composition of synthetic crudes. As part of that objective, the gasoline supplement options were added to consider their role with synthetic materials in the crude slate. There was no intention to evaluate a range of concentrations or to use mixtures of components in the blend. Also, there was no plan to consider the economics of each component relative to the others since this would be better evaluated by an individual refinery with its unique location, transportation, and price factors.

Blending values of the gasoline supplements are given in Table 5.1 . These properties were used to blend with other gasoline components to produce optimum gasoline blends meeting specifications in each case. This is a significant difference from gasohol where the ethanol is added to finished gacoline already meeting specifications, thereby changing its octanes and volatility properties.

It should be noted that the alcohol blending values for vapor pressure and percent distilled at $160^{\circ} \mathrm{F}$ are valid only at the 10 percent level since these properties show nonlinear behavior as alcohol concentration is varied. Also, volatility parameters for methanol assume the absence of butane in blends. Significant volumes of methannl rannot be tolerated in blends contalning butane without causing potentlal vapor lock problems. Fur exainple, a Vapor Lock Index (VLI) is often specifled for gasoline. The equation for this index is:

$$
\left.V L I=\operatorname{RVP}+0.13 \text { (percent distilled at } 158^{\circ} \mathrm{F} .\right)
$$

A typical 1imit of 14.7 VLI is specified for gasolines. This limit would be met hy a gasoline with 10.1 pound RVP and 35 percent distilled at $158^{\circ} \mathrm{F}$. 
The boiling point of methanol is $149^{\circ} \mathrm{F}$ but it makes azeotropic mixtures with hydrocarbons which boll at lower temperatures. Thus the percent distilled at $158^{\circ} \mathrm{F}$ is increased by an amount more than the percentage of methanol added. This effect on distillation is the basis for the high blending value for percent distilled at $160^{\circ} \mathrm{F}$ on Table 5.1. Also, at over 5 percent concentration, methanol raj.ses RVP about 3 pounds which would increase the first term in the VLI equation.

The blending octane numbers in Table 5.1 are based on a review of numerous studies by other researchers (References 1-17). Considerable variation in alcohol and MTBE blending octane values was reported in the literature. This variation results from a combination of factors including:

1. Non-1inear blending resulting from factors such as:

a. Variation with alcohol concentration, although calculation techniques can be used to minimize this effect.

b. A trend toward higher alcohol blending octanes with lower octane gasoline base stocks.

c. Variation with hydrocarbon types in the gasoline base stock, particularly aromatics.

2. Difficulty in measuring the octane due to differences in characteristics and detection of knock with blends containing oxygenated compounds.

The blending octanes selected for use in the mode1 tend toward the conservative or low side of the range of reported data.

The change in volumetric fuel economy by adding alcohols to gasoline depends on the carburetor adjustment. Miles per gallon may increase, decrease, or stay the same with alcohol in the gasoline depending on the a1r/fuel ratio in the individual vehicle (7). Since this condition cannot be predicted and the effect is smal1 (about $5 \%$ of fuel use) no adjustment was made to gasoline demand volumes.

A potential problem may occur with methanol blends in the distribution system. If a gasoline containing butane and onp rontaining methanol arc mixed, the resulting blend could exceed the VLI limits even if both blends were within specifications separately. This type of mixing may occur in the distribution system and would be likely to occur in the automobile gasoline tank which is typically not supplied consistently from a single source.

The preceding comments on non-linear blending behavior are directed primarily at the oxygenated compounds and do not apply to the synthetic naphtha blending component. Since this is a hydrocarbon stream, its published properties (18) would be expected to blend linearly within the limits of variation for normal gasoline components. 


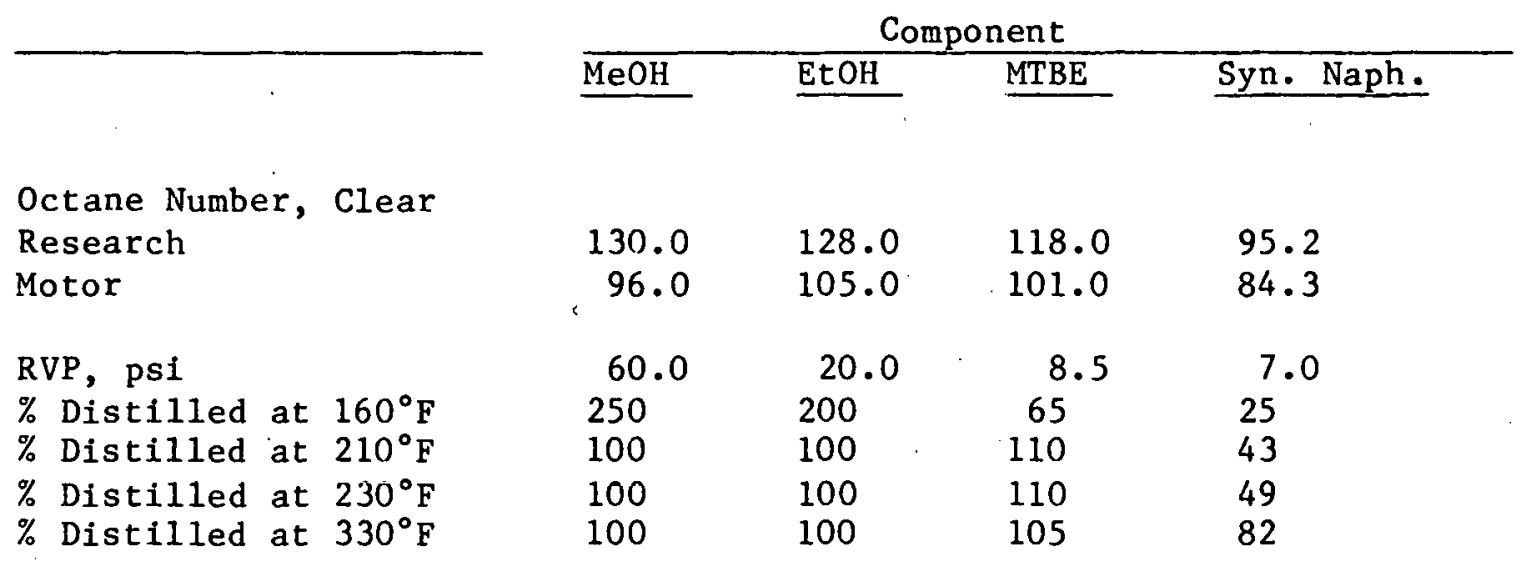

\section{SECTION REFERENCES}

1. Eccelston, B.H., and Cox, F.W., "Physical Properties of Gasoline/Methanol Mixtures," Department of Energy, Report BERC/RI-76/12, January 1977.

2. Cox, F.W., "The Physical Properties of Gasoline/Alcohol Automotive Fuels," Alcohol Fuels Technology, Third International Symposium, Asilomar, CA, May 1979.

3. Johnson, R.T., and Riley, R.K., "Evaluation of Methyl Alcohol as a Vehicle Fuel Extender," Final Report DOT-TST-76-50, August 1975.

4. Keller, J.L., Nakaguchi, G.M. and Ware, J.C., "Methanol Fuel Modification for Highway Vehicle Use," DOE Report HCP/W3683-18, July 1978.

5. Vehicle Test Program, Standard Oil Company of Ohio Internal Report, July 1979.

6. Keller, J.L., "Methanol and Ethanol Fuels for Modern Cars," Paper. No. 08-79, API Refining Keeting, May 1979.

7. Brinkman, N.D., Gallopoulos, N.E. and Jackson, M.W., "Exhaust Emissions, Fuel Economy and Driveability of Vehicles Fueled With Alcohol-Gasoline Blends," SAE Paper 750120, February 1975.

8. Lawrence, R., "Gasohol Test Program," Environmental Protection Agency, Report 79-4A, December 1978.

9. Pecci, G., and Gartbaldi, P., "Methy1 Fuel and its Effect on Crude Oil Consumption," Alcohol Fuels Technology, Third International Symposium, Asilomar, CA, May 1979. 
10. Garibaldi, P., and Pecci, G., "Methanol and Ethanol as Raw Materials for the Synthesis of High Octane Components," International Symposium on Alcohol Fuel Technology, Wolfsburg, Germany, November 1978.

11. Harrington, J.A., and Brehob, D.O., and Schanerberger, E.H., "Evaluation of MTBE as a Gasoline Blending Component," Alcohol Fuels Technology, Third International Symposium, Asilomar, CA, May 1979.

12. Chase, J.D., and Woods, H.J., "MTBE and TAME a Good Octane Boosting Combo," Oil and Gas Journal, April 9, 1979.

13. Ciskos, R., etal, "Low Lead Fuels with MTBE and $C_{4}$ Alcohols," Hydrocarbon Processing, July 1976.

14. Dartne11, P.L., and Campbe11, K., "Other Aspects of MTBE/Methanol Use," Oil and Gas Journa1, Nov ember 13, 1978.

15. Unzelman, G.H., and Michalski, G.W., "Octane Tmprovement Economicom Antiknocks and Alternatives, NPRA Paper AM-79-46, March 1979.

16. Pecci, G. and Floris, T., "Ether Ups Antiknock of Gasoline," Hydrocarbon Processing, December 1977.

17. "Detailed Blending Data for MTBE," DuPont Tech Brief, No. 781,6, November 1978.

18. Voltz, S.E. and Wise, J.J., "Development Studies on Conversion of Methanol and Related Oxygenates to Gasoline," Final Report FE-177325, November, 1976. 
VI. RESULTS AND DISCUSSIONS

Results of the refinery model runs are presented in this section for all three regions. Data summaries are grouped in categories so that discussion of conclusions can include comparisons among regions. The main categories are:

- Overall summaries of raw materials, products, utilities, and additions to process units.

- Compositions of highway transportation fuels.

- Impacts of synthetic crudes and gasoline supplements on raw materials and refinery energy consumption.

- Relative investment costs for future expansion with and without synthetic crudes and gasoline supplements.

- Process flowsheets and tables showing volumes of syncrude components through each process step.

- Product quality data on highway fuel blends.

A. Overall Summaries and Case Descriptions

Tables 6.1 through 6.6 contain overall summaries of the individual case runs. The first three tables show RAW MATERIALS purchased and PRODUCTS sold in three groups of cases:

Table 6.1 - Shale Dil Cases
Rocky Mountain Region

Table 6.2 - Coal Oil Cases Rocky Mountain Region

Table 6.3 - Shale and Coal Oil Cases Mid-Contlnent and Great Lakes Regions

In the second group, Tables 6.4 through 6.6 , information is tabulated on UTILITIES consumed and NEW CAPACITY added to major processing units in a parallel grouping of cases. Data selected from these summaries are discussed in more detail later in this section.

Since all data tables have similar structure, a description of cases is given below to facilitate identification by case number and an abbreviated name. The cases are the same as outlined on Table 2.1, Project Case Study Schedule, in Section II. The A or $B$ on some case numbers refers to repeat runs made with those computer cases. 
TABLE 6.1 RAW MAT

SHFLE OCL CASES

ROCKY MOUNTAIN REGION

CRUDE

Case No.

Description

RAW MATERIALS, B/D

Low Sulfur Crude

High Sulfur Crude

Normal Butane

Iso-Butane

Natural Gasoline

Shale otl

Coal 011

$\stackrel{\infty}{\infty}$

Supplement

TOTAL RAW MATERIALS

PRODUCTS, B/D

LPG

Regular Unleaded

Premium Unleaded

Broadcut Fuel

Kerosene Jet Fuel

No. 2 Diesel

No. 2 Fuel 011

No. 6 Low Sulfur

No. 6 High Sulfur

Coke

Lubes \& Asphalt

Plant Fuel

(Gain) or Loss

TOTAL PRODUCTS
PETROLEEM

\begin{tabular}{cl}
1 & \multicolumn{1}{c}{16} \\
& Broadcut \\
Base & Fuel \\
\hline
\end{tabular}

$\begin{array}{rr}69.925 & 69166 \\ 48933 & 48402 \\ 1646 & 0 \\ 1386 & 634 \\ 4200 & 692 \\ 0 & 0 \\ 0 & 0 \\ 0 & 0\end{array}$

126090

$1: 8894$

1455

14300

0
10400

19400

21500

8500

4600

1000

$50 \mathrm{CO}$

7620

(2095)

126090

3350

20000

8600

$\mathbf{L} 400$

10400

19400

21500

3500

4600

1000

5000

1226

(0ㅕ)

118894

SHALE OI-

Product Op:ions

Gasoline Supplements

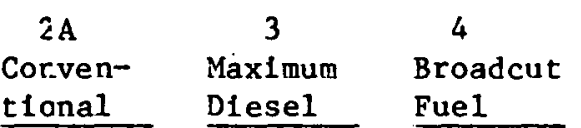

tlonal

\section{$26814 \quad 28144 \quad 25561$}

46960 . $49289 \quad 44756$

$1579 \quad 441 \quad 796$

1477

4200

42000

0

42000

0
4200

42000

$\begin{array}{ll}0 & 0 \\ 0 & 0\end{array}$

123130

119874

117323

\section{9}

Methano1 Ethano1 MTBE

$\begin{array}{rrrr}28222 & 28587 & 26096 & 25141 \\ 49425 & 50064 & 45703 & 44031 \\ 0 & 0 & 1022 & 1616 \\ 1495 & 0 & 0 & 0 \\ 1941 & 73 & 4200 & 4200 \\ 4200 C & 42000 & 42000 & 42000 \\ C & 0 & 0 & 0 \\ 4770 & 4770 & 4770 & 11475 \\ 127853 & 125494 & 123791 & 128463\end{array}$

\section{2}

33400

14300

$$
\begin{array}{r}
0 \\
10400
\end{array}
$$

19430

21530

85100

4600

1000

6000

3568

(1190)

\section{9}

23400

10000

0
10400

30000

21500

8500

4600

1000

6000

4433

:1799)

$1231 \equiv 0$

1:9874
$3096 \quad 2048$

$33400 \quad 33400$

$14300 \quad I 4300$

$\begin{array}{rr}0 & 0 \\ 10400 & 10400\end{array}$

$19400 \quad 19400$

21500

8500

4500

1000

61) 00

5.951

(1294)

127853

¿1500

8500

4600

1000

6000

6350

(2004)

125494
11

Synthetlc

Naphtha

5141

1616

0
4200

28463

1833

33400

10400

19400

21500

8500

4600

1000

3252

4278

128463 
TABLE 6.2 RAW MATERIALS AND PRODUCTS

COAL OIL CASES

ROCKY MOUNTAIN REGION

CRUDE

Case No.

Deszription

RAW MATERIALS, B/D

Low Sulfur Crude

High Sulfur Crude

Normal Butane

Iso-Butane

Natural-Gasoline

Shale $0 \pm 1$

Coal 011

of Supplement

TOTAL RAW MATERIALS

PRCDUCTS, B/D

Regular Unleaded

Premium Unleaded

Broadcut Fuel

Kerosene Jet Fue1

No. 2 Diesel

$19<00$

No: 2 Fuel oil

No. 6 Low Sulfur

No. 6 High Sulfur

Coke

Labes \& Asphalt

Plant Fuel

(Gain) or Loss

TOTAL PRODUCTS
PETROLEUM

COAL OIL

Product Options

\begin{tabular}{c}
1 \\
Base \\
\hline \\
69925 \\
48933 \\
1646 \\
1386 \\
4200 \\
0 \\
0 \\
0
\end{tabular}

126090

\section{5}

33400

14300

10400

19400

21500

8500

4600

1000

6000

7620

(2096)

3350

20000

8600

15400

10400

19400 .

21500

8500

4600

1000

6000

1226

(1082)

$126090 \quad 118894$

\section{$5 A$}

Conven-

tional

$5 \mathrm{~B}$

Conven-

tional

\section{6}

47428

2172

0
4200

0

28800
0

123246

1414

33400

14300

10400

19400

21500 :

8500

4600

1000

6000

- 6146

(3414)

1249
33400

33400

14300

10400

19400

21500

8500

4600

1000

6000

3273
$(2705)$

(2705)

\begin{abstract}
123246
\end{abstract}

\begin{tabular}{cl}
\multicolumn{1}{c}{6} & \multicolumn{1}{c}{$7 \mathrm{~A}$} \\
Maximum & Broadcut \\
Diesel & Fuel \\
\hline
\end{tabular}

$\begin{array}{rr}44541 & 38878 \\ 51973 & 45365 \\ 0 & 619 \\ 0 & 0 \\ 0 & 2547 \\ 0 & 0 \\ 28800 & 28800 \\ 0 & 0\end{array}$

125314

116209

4514

23400

10000

0
10400

30000

21500

8500

4600

1000

6000

9197

(3797)

2312

20000

8600

15400

10400

19400

21500

8500

4600

1000

6000

(2224)

125314
Gasoline Supplements

\begin{tabular}{cccc}
12 & 13 & 14 & $\begin{array}{c}15 \mathrm{~A} \\
\text { Synthetic } \\
\text { Methano1 }\end{array}$ \\
\hline
\end{tabular}

$\begin{array}{rrrr}40646 & 40646 & 40646 & 40646 \\ 47428 & 47428 & 47428 & 47428 \\ 0 & 0 & 0 & 334 \\ 1294 & 0 & 0 & 0 \\ 4200 & 4200 & 4200 & 4200 \\ 0 & 0 & 0 & 0 \\ 28800 & 28800 & 28800 & 28800 \\ 4770 & 4770 & 4770 & 11475 \\ 127138 & 125844 & 125844 & 132883\end{array}$

$\begin{array}{llll}2616 & 2098 & 2811 & 4216\end{array}$

$\begin{array}{rrrr}33400 & 33400 & 33400 & 33400\end{array}$

$\begin{array}{llll}14300 & 14300 & 14300 & 14300\end{array}$

$\begin{array}{rrrr}0 & 0 & 0 & 0 \\ 10400 & 10400 & 10400 & 10400\end{array}$

$\begin{array}{llll}19400 & 19400 & 19400 & 19400\end{array}$

$21500 \quad 21500 \quad 21500 \quad 21500$

$\begin{array}{llll}8500 & 8500 & 8500 & 8500\end{array}$

$4600 \quad 4600 \quad 4600.4600$

$1000 \quad 1000.1000 .1000$

$\begin{array}{llll}6000 & 6000 & 6000 & 6000\end{array}$

$\begin{array}{llll}8235 & 8126 & 7908 & 7979\end{array}$

$\begin{array}{llll}(2813) & (3480) & (3975) & 1588\end{array}$

$\begin{array}{lllll}116209 & 127138 & 125844 & 125844 & 132883\end{array}$ 
TABLE 6.3 RAW MATERIALS AND PRODUCTS

SHALE AND COAL OIL CASES

MID-CONTINENT AND GREAT LAKES REGIONS

REGION

CRUDE

Case No.

Description

RAW MATERIALS, B/D

Local

Inter-PADD sour

Inter-PADD sweet

North slope

Imported Swaet

Imported Sour

Normal Buta.ne

Iso-Butane

Shale Oil

Coal 011

TOTAL RAW MATERIALS

MID-CONTINENT

PETROLEUM

SHALE AMD COAZ OILS

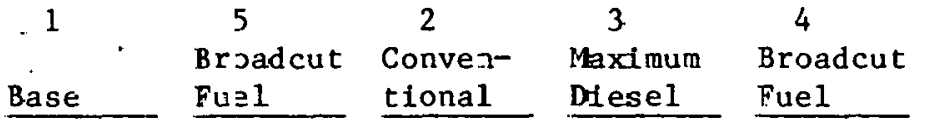

tional

Diesel

Fuel

210.00

8140

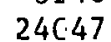

\section{0}

3140

21000

8140

\section{0}

8140
5959

..

$\varsigma 15$
$\varepsilon 69$

$\varepsilon 69$
0
0

0

54971

$$
\begin{array}{r}
1022 \\
438
\end{array}
$$

4.38

0
0

52437

$$
\text { . }
$$

1283

789
9380

6240

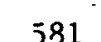

581
530

9380

6240

21000

$8140^{\circ}$

4931

54193

51830

1418

594

9380

6240

51703

104932

758

10911

10976
8376

8376

3387

3387
10220

10220
5551

$\because 571$

1923

0

2876

808

(620)

(813)

$54971 \quad 52437$

$\begin{array}{rr}935 & 741 \\ 18185 & -2.30 \\ 7794 & 5455 \\ 0 & 0 \\ 3387 & 3387 \\ 1022 C & -5987 \\ 5551 & 5551 \\ 3571 & 3571 \\ 1923 & 1923 \\ C & 0 \\ 2876 & 2876 \\ 629 & 384 \\ (876) & (775)\end{array}$

559
10911

4676

4676
8376

3387

10220

5551

3571

1923

0
2876

2876
284

(631)

54193

- 18.30

51703
2214

29846

12791

0

15702

21684

5318

2863

2106

7114

2363

(2760)

TOTAL PRODUCTS

104932

1581

17895

7669

13766

5691

15702

21684

5318

2863

2139

7114

1532

(1863)

2004
29846

12791

5691

5691
15702

21684

5318

2863

1414

7114

1708

(2762)

$1) 1091$

103373

34

Maximum Broadcut

Diese1

Fue1

9430

26190

6145

39810

1104

755

9680

6450

99564

102723

2997

1487

$20892 \quad 17895$

$8954 \quad 7669$

13766

5691

5691

$25183 \quad 15702$

$21684 \quad 21684$

$5318 \quad 5318$

$2863 \quad 2863$

$1802 \quad 1407$

7114

1162

(2194)

99564 
TABLE 6.4

UTILITIES AND NEW. FACILITIES

SHALE OIL CASES

ROCKY MOUNTAIN REGION

PETROLEUM

CRUDE

Case No.

Description

UTILITIES

Plant Fuel

Purchased Fuel

Total Fuel; MMBTU/D

Cat and Chemicals, \$/D

Sulfur Made, Tons/D

\begin{tabular}{r}
1 \\
Base \\
\hline \\
37968 \\
760 \\
38728 \\
8221 \\
98
\end{tabular}

16

Broadcut

Fue 1

7673
26426
34099
6797
101

18617

\section{7}

18998

102
NEW FACILITIES CAPACITY, B/D

Crude Distillation
Vacuum Distillation
Naphtha Hydrotreater
Catalytic Reformer
Kero/Gas Oil
Hydrotreater
Visbreaker
Hydrocracker
Catalytic Cracker
Alkylaticn
Hydrogen, MSCF/D
Delayed Coker

19312
14759
3667
3162
21524
1023
0
0
0
0
0

17568
14529
0
0
20618
0
0
0
0
0
99

SHALE OIL

Product Options

Gasoline Supplements

\begin{tabular}{|c|c|c|}
\hline $2 A$ & 3 & 4 \\
\hline Conven- & Maximum & Broadcut \\
\hline tional & Diese1 & Fue 1 \\
\hline
\end{tabular}

8

9

Methanol Ethanol

21922

23435

45357

6909

$$
32753
$$

39662

17377

18673

108

93

33966
11132
45098
18843
110

30776

11734

42510

17871

112

17791
97

24599

16664

41263

26734

43688

32749

49
93

16962
1473
0
0

$$
\begin{array}{r}
23846 \\
5902 \\
2473 \\
1219
\end{array}
$$

97989

98287
0

104170

99330
0
0
0
0
63199
0

$$
\begin{array}{r}
24851 \\
6581 \\
2657
\end{array}
$$$$
\begin{array}{r}
100630 \\
0 \\
0 \\
0 \\
0 \\
64609 \\
0
\end{array}
$$

17999
2392
0
0

15372

726

0

$\begin{array}{rr}100565 & 99380 \\ 0 & 0 \\ 0 & 0 \\ 0 & 0 \\ 0 & 0 \\ 66857 & 64929 \\ 0 & 0\end{array}$


TABLE 6.5 UTILTTIES AND NEW FACILITIES

COAL OIL CASES

ROCKY MOUNTAIN REGION

\begin{tabular}{|c|c|c|c|c|c|c|c|c|c|c|}
\hline \multirow[t]{2}{*}{ CRUDE } & \multicolumn{2}{|c|}{ PETROLEUM } & \multicolumn{8}{|c|}{ COAL OIL } \\
\hline & & \multirow[b]{2}{*}{$\begin{array}{l}16 \\
\text { Broadcut } \\
\text { Fue1. } \\
\end{array}$} & \multicolumn{4}{|c|}{ Product Options } & \multicolumn{4}{|c|}{ Gasoline Supplements } \\
\hline $\begin{array}{l}\text { Case No. } \\
\text { Description }\end{array}$ & $\begin{array}{c}1 \\
\text { Base } \\
\end{array}$ & & $\begin{array}{l}\quad 5 A \\
\text { Conven- } \\
\text { tlonal } \\
\end{array}$ & $\begin{array}{l}\quad \bar{B} \\
\text { Conven- } \\
\text { tIona1 } \\
\end{array}$ & \begin{tabular}{l}
\multicolumn{1}{c}{6} \\
Maximum \\
Diesel \\
\end{tabular} & $\begin{array}{l}\quad 7 \text { A } \\
\text { Broadcut } \\
\text { Fuel }\end{array}$ & $\begin{array}{c}12 \\
\text { Methanol } \\
\end{array}$ & $\begin{array}{c}13 \\
\text { Ethanol }\end{array}$ & $\begin{array}{r}14 \\
\text { MTBE }\end{array}$ & $\begin{array}{l}\text { 15A } \\
\text { Synthetic } \\
\text { Naphtha }\end{array}$ \\
\hline \multicolumn{11}{|l|}{ UTILITIES } \\
\hline $\begin{array}{l}\text { Plant Fuel } \\
\text { Purchased Fuel }\end{array}$ & $\begin{array}{r}37968 \\
760\end{array}$ & $\begin{array}{r}7673 \\
26426\end{array}$ & $\begin{array}{l}29049 \\
10483\end{array}$ & $\begin{array}{l}16360 \\
23231\end{array}$ & $\begin{array}{r}45239 \\
0\end{array}$ & $\begin{array}{r}4593 \\
30239\end{array}$ & $\begin{array}{r}39877 \\
465\end{array}$ & $\begin{array}{r}37603 \\
0\end{array}$ & $\begin{array}{r}37806 \\
0\end{array}$ & $\begin{array}{r}39658 \\
-0\end{array}$ \\
\hline Total Fuel, MMBTU/D & 38728 & 34099 & 39532 & 39591 & 45239 & 34832 & 39342 & 37603 & 37806 & 39658 \\
\hline $\begin{array}{l}\text { Cat and Chemicals, } \$ / \\
\text { Sulfur Made, Tons/D }\end{array}$ & $\begin{array}{r}8221 \\
98\end{array}$ & $\begin{array}{r}6 ? 97 \\
: 01\end{array}$ & $\begin{array}{r}8031 \\
85\end{array}$ & $\begin{array}{r}3398 \\
89\end{array}$ & $\begin{array}{r}9440 \\
99\end{array}$ & $\begin{array}{r}7402 \\
77\end{array}$ & $\begin{array}{r}8599 \\
86\end{array}$ & $\begin{array}{r}7950 \\
88\end{array}$ & $\begin{array}{r}7471 \\
86\end{array}$ & $\begin{array}{r}21901 \\
79\end{array}$ \\
\hline \multicolumn{11}{|c|}{ NEW FACILITIES CAPACITY 3/D } \\
\hline Crude Distillation & 19312 & 17568 & 17834 & 15019 & 26273 & 14003 & 18863 & 17834 & $1783 ̣ 4$ & 17834 \\
\hline Vacuum Distillation & 14759 & 14259 & 5256 & 3773 & 9338 & 3029 & 5250 & 5250 & 5250 & 3993 \\
\hline Naphtha Hydrotreater & 3667 & 0 & 8237 & 7499 & 9227 & 257 & 8989 & 7802 & 6302 & 8847 \\
\hline $\begin{array}{l}\text { Catalytic Reiormer } \\
\text { Kero/Gas Oil }\end{array}$ & 3162 & .0 & 4184 & 51.17 & 6827 & 0 & 3923 & 2550 & 3069 & 6883 \\
\hline Hydrotreater & 21524 & 20613 & 37075 & 37608 & 34320 & 30266 & 38898 & 38256 & 37199 & 35310 \\
\hline Visbreaker & 1023 & 0 & 0 & 0 & 0 & 0 & 0 & 0 & 0 & 0 \\
\hline Hydrocracker & 0 & 0 & 575 & 0 & 4906 & 1485 & 240 & 1595 & 2769 & 1818 \\
\hline Catalytic Cracker & 0 & D & 0 & 0 & 0 & 0 & 0 & 0 & 0 & 0 \\
\hline Alkylation & 0 & 0 & 0 & 0 & 0 & 0 & 0 & 0 & 0 & 0 \\
\hline Hydrogen, MSCF/D & 0 & 0 . & 391 & 1057 & 4428 & 7322 & 2034 & 4687 & 5351 & 0 \\
\hline Delayed Coker & 0 & 99 & 132 & 0 & 61 & 104 & 0 & 0 & 253 & 595 \\
\hline
\end{tabular}


TABLE 6.6 UTILITIES AND NEW FACILITIES

SHALE AND COAL OIL CASES

MID-CONTINENT AND GREAT LAKES REGIONS

REGION

CRUDE

Case No.

Description

MID-CONTINENT

$$
1
$$

Base

5

Broadcut Eue1

\section{UTILITIES}

Plant Fuel

Purchased Fuel

Total Fuel, MABTU/D

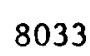

9980

18013

$$
\begin{array}{r}
5059 \\
1035.4 \\
15393
\end{array}
$$

3519

Cat and Chemicals, \$/D 4480

$\vec{\omega}$ Sulfur Made, Trns/D

9

NEW FACILITIES CAPACITY, B/D

Crude Distillation
Vacuum Distillation
Naphtha Hydrotreater
Catalytic Reformer
Kero/Gas Oil
Hydrotreater
Visbreaker
Hydrocracker
Catalytic Cracker
Alkylation
Hydrogen, MSCF/D
Delayed Coker

3187
6210
0
1372
0
1262
0
0
0
0
0

\begin{tabular}{|c|c|c|}
\hline 2 & 3 & 4 \\
\hline & $\begin{array}{l}\text { Maximum } \\
\text { Diesel }\end{array}$ & $\begin{array}{l}\text { Broadcut } \\
\text { Fuel }\end{array}$ \\
\hline
\end{tabular}

\section{GREAT LAKES}

PETROLEUM SHALE AND COAL OILS

\begin{tabular}{cl}
1 & \multicolumn{1}{c}{5} \\
Base & $\begin{array}{c}\text { Broadcut } \\
\text { Fuel }\end{array}$ \\
\hline
\end{tabular}

2

2

Conven-

tional

(a)

Maximum

Diese1

Broadcut

Fuel t.

$\begin{array}{rrr}4009 & 2444 & 1860 \\ 16092 & 15897 & 14526 \\ 20101 & 18341 & 16332 \\ 5922 & 5747 & 5484 \\ 15 & 15 & 14\end{array}$

14936
27742
42678
9271
55

\section{2}

28367

38059

10884

33244

44128

14039

27369

41408

8098

117.47

11090

63

7404

31646

39050

10868

$\begin{array}{rrr}65 & 11090 & 10868 \\ & 63 & 63\end{array}$

$\begin{array}{rr}927 & 3267 \\ 5388 & 3405 \\ 0 & 2256 \\ 0 & 2473\end{array}$

$\begin{array}{rr}1865 & 837 \\ 2686 & 2214 \\ 0 & 0 \\ 0 & 0\end{array}$

3549
11012
0
0
5504
11528
0
0
0
0
0

0
9379
0
0
3966
11651
0
0
0
0
0

2637
7877
0
0
31031
10101
0
0
0
15707
0

2859

7964

0
6412
0
0

$\begin{array}{rr}0 & 21493 \\ 1311 & : \quad 0 \\ 0 & 0 \\ 0 & 0 \\ 0 & 0 \\ 0 & 8887 \\ 0 & 0\end{array}$

21582
77
38
0
0
11997
0

20293

$\begin{array}{rr}25337 & 25692 \\ 6388 & 9475 \\ 0 & 0 \\ 0 & 0 \\ 0 & 0 \\ 15998 & 18272 \\ 0 & 0\end{array}$




\begin{tabular}{|c|c|c|}
\hline Case No. & Name & Description \\
\hline $\begin{array}{l}1 \\
16\end{array}$ & $\begin{array}{l}\text { BASE } \\
\text { BCF }\end{array}$ & $\begin{array}{l}\text { Petroleum Crudes. } \\
\text { Base Case: } 1995 \text { Product slate. } \\
\text { Broadcut fuel for part of gasoline. }\end{array}$ \\
\hline $\begin{array}{l}2 \mathrm{~A} \\
3 \\
4\end{array}$ & $\begin{array}{l}\text { SHALE } \\
\text { MAX D } \\
\text { BCF }\end{array}$ & $\begin{array}{l}\text { Shale oil in crude slate. Product options series. } \\
1995 \text { Product slate. } \\
\text { Maximum diesel for part of gasoline. } \\
\text { Broadcut fuel for part of gasoline. }\end{array}$ \\
\hline $\begin{array}{l}5 A, 5 B \\
6 \\
7 A\end{array}$ & $\begin{array}{l}\text { COAL } \\
\text { MAX D } \\
\text { BCF }\end{array}$ & $\begin{array}{l}\text { Coal oil in crude slate. Product options series. } \\
1995 \text { Product slate. } \\
\text { Maximum diesel for part of gasoline. } \\
\text { Broadcut fuel for part of gasoline. }\end{array}$ \\
\hline $\begin{array}{l}8 \\
9 \\
10 \\
11\end{array}$ & $\begin{array}{l}\text { MEOH } \\
\text { ETOH } \\
\text { MTBE } \\
\text { SYNNAPH }\end{array}$ & $\begin{array}{l}\text { Ehale oil in crude slate. Gasoline supplements. } \\
1995 \text { Product slate. } \\
\text { Methanol supplement. } \\
\text { Ethanol supplement. } \\
\text { Methy-tert-butyl ether supplement. } \\
\text { Synthetic naphtha from methanol. }\end{array}$ \\
\hline $\begin{array}{l}\text { Be } \\
\text { and rev } \\
\text { Supplcme } \\
\text { option }\end{array}$ & $\begin{array}{l}\text { MEOH } \\
\text { ETOH } \\
\text { MTBE } \\
\text { SYNAPH } \\
\text { f chang } \\
\text { Rocky Mr } \\
\text { es 12, } \\
\text { and 7A }\end{array}$ & $\begin{array}{l}\text { Coal oil in crude slate. Sasoline Eupplement3. } \\
1995 \text { product slate. } \\
\text { Methanol supplement. } \\
\text { Ethanol supplement. } \\
\text { Methy-tert-butyl ether supplement. } \\
\text { Synthetic naphtha from methanol. } \\
\text { e in model structure after initial cases were run } \\
\text { n Coal Case 5A should be compared with gasoline } \\
\text { and 15A. Case 5B is consistent with product }\end{array}$ \\
\hline
\end{tabular}

\section{Mid-Continent and Great Lakes Regions}

\begin{tabular}{ll} 
Case Nn. & \multicolumn{1}{c}{ Name } \\
\cline { 2 - 2 } 1 & \\
5 & BASE \\
& BCF \\
& \\
2 & SYNCRUDE \\
3 & MAX D D \\
4 & BCF
\end{tabular}

Description

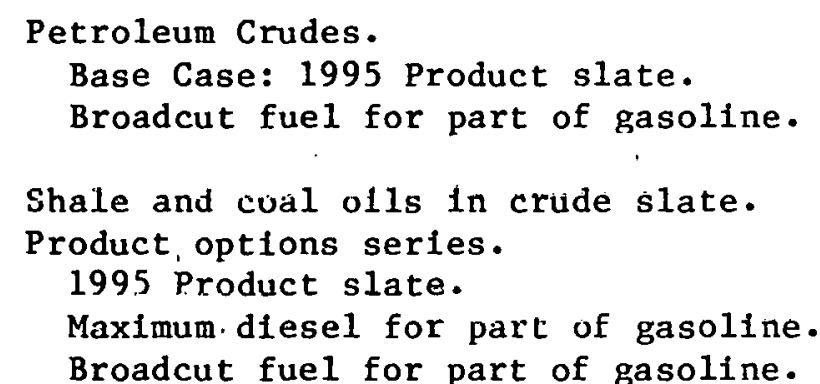




\section{B. Fuels Compositions}

The major objective of this study was to determine the compositions of highway transportation fuels that would be expected in the future when syncrudes derived from coal and shale become a significant fraction of the refining industry's total raw material. Additionally, the effect on the product compositions of adding nonpetroleum-derived gasoline components to the gasoline production were to be determined.

The linear programming model combines a variety of refinery streams to produce a final blend. Unfortunately, this is often so wide a variety as to become unmanageable in a laboratory program. For example, there were over 28 different streams used in preparing the regular no-lead gasolines. In order to reduce the number of components, a Lab Blend Definition Algorithm was developed. The Lab Blend Definition Algorithm Involves translating the RPMS components used in the gasoline pool, diesel fuel, and broadcut fuel into a reasonable number of components which-could be obtained for use in laboratory formulation. For the gasoline pool, the following streams wil1 be employed:

TABLE 6.7 GASOLINE POOL COMPONENTS

Petroleum Shale $\quad \underline{\text { Coal }}$

Light Straight Run $\quad \mathrm{X}$

Reformate - 100 RON

90 RON

$\mathrm{x}$

$\mathrm{X}$

$\mathrm{X}$

$\mathrm{X}$

C3-C4 Alkylate

$\mathrm{X}$

Cat Gasoline $-\mathrm{C} 5-250^{\circ} \mathrm{F}$

$\mathrm{X}$

$\mathrm{X}$

$\mathrm{X}$

$\mathrm{X}$

Butane

$\mathrm{X}$

Natural Gasoline . X

Methanol ' ' X

Ethano1 X

MTBE $\quad \mathrm{X}$

Synthetic Naphtha $\mathrm{X}$ 
Those components being used for diesel fuel blending will include the following:

TABLE 6.8 DIESEL FUEL COMPONENTS

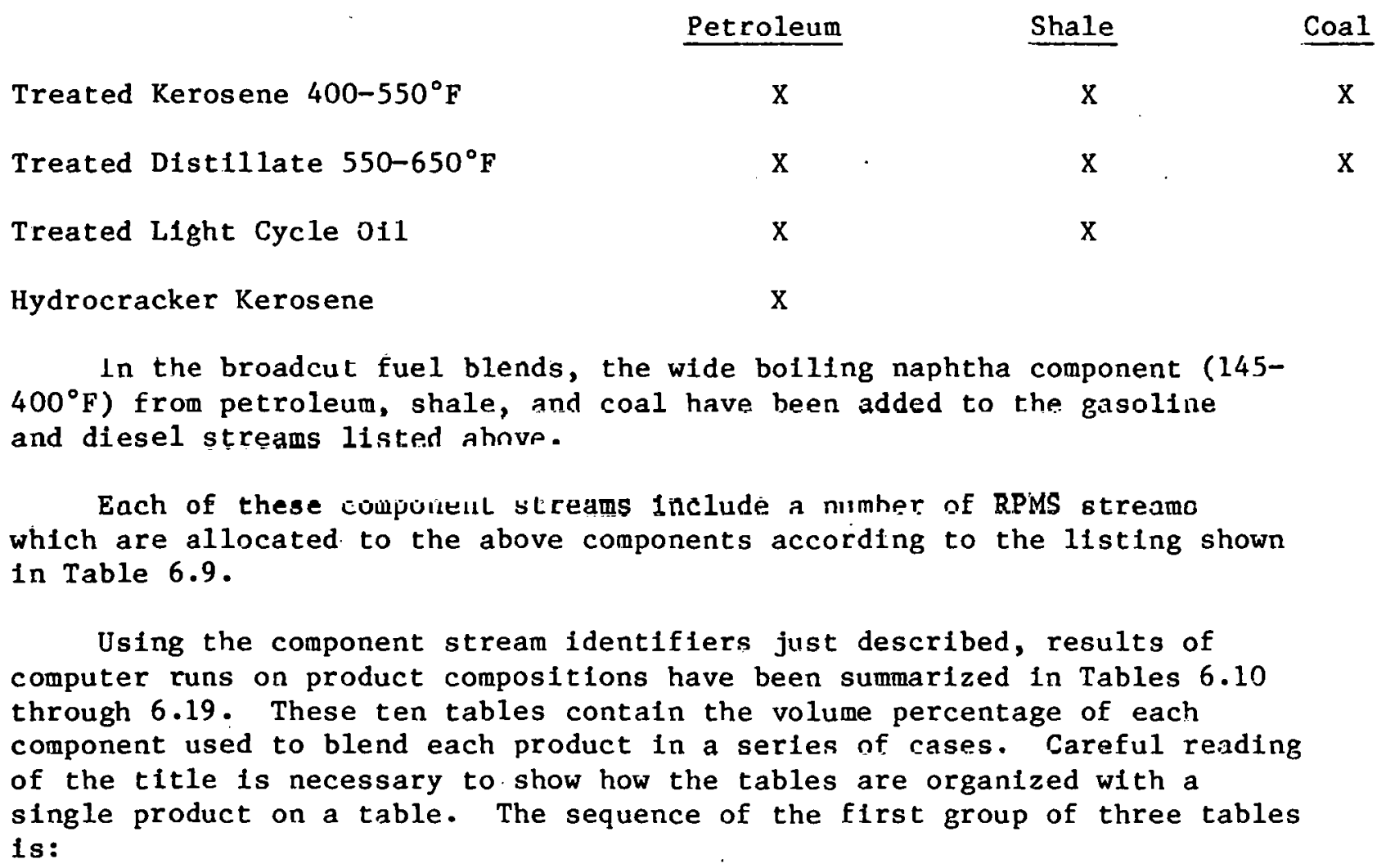

Shale ofl cases, Rocky Mountain region

Table 6.10 Regular Unleaded Casoline.

Table 6.11 Premium Unleadenl Gasollne

Table 6.12 Diesel Fuel

The sequence is repeated for two other groups of three:

Coal oll cases, Rocky Mountain reginn

Shale and coal oll cases, Mid-Continent and Great Lakes regions

Table 6.19, the last tabulation in the group, contains broadcut fuel compositions from all cases in which this product was made.

One of the goals within this study was to produce a variety of blends which can realistically be produced in typical refinertes. Table 6.20 summarizes the ranges in compostions which have been obtained from the refinery cases.

Synthetic components are identified where their properties could be expected to differ from a similar petroleum fraction. In gasolines, 
TABLE 6.9 RPMS STREAM ALLOCATION

Blending Component

Light Straight Run

Reformate

C3-C4 Alkylate

Cat Gasoline

Butanes

Treated Kerosene $400-550^{\circ} \mathrm{F}$

Treated Distillate $550-650^{\circ} \mathrm{F}$

Treated I.1ght Cycle 011

Hydrocracker Kerosene
RPMS Streams

RPMS Name

85-145 SR Gaso

1LL

Mixed C5's

Thermal C5's

C5-IC6 Hydrocrackate

Normal Pentane

Natural Gasoline

90 RON Reformate

95 RON Reformate

100 RON Reformate

Propylene Alkylate

Butylene Alkylate

Amylene Alkylate

C5-430 Cat Gaso (T)

250-410 Cat Gaso (S)(T)

C5-430 Cat Gaso (S)(T)

C5-250 Cat Gaso '(S)(T)

250-410 Cat Gaso (T)

C5-250 Cat Gaso (T)

C5-250 Coker Gaso

C5-420 Poly Gaso

MC5

TC5

LHG

NC5

N12

F90

F95

F00

LA3

LA4

LA5

FCG

HWG

FWG

LWG

HCG

LCG

LKG

POL

n-Butane

NC4

$\mathrm{C} 4 \mathrm{U}$

IC4

Iso-butane

MC4

200-330 SR Gaso ( $T$ )

1MS

400-550 SR Kero (T)

1SK

400-550 SR Kero (T)

250-400 Coker Gaso (I')

2SK

HKG

400-550 Htr Kero

SKH

550-650 SR Dist (T) ISR

550-650 SR Dist ( $T$ ) 2SR

375-650 H'Crack Dist. . HCD

550-650 Htr. Sr Dist. SRH

430-660 Htr Cy Oil : LCH

400-550 Hck Kero HCK

170-375 H'crackate HHG 
TABLE 6.10 REGULAR URIEADED GASOLINE COMPOSITION

SHALE JIL CAS $\Xi S$

ROCKY MOUNTAIN REGION

CRUDE

Description

REGULAR UNLEADED,

Light Straight Run

Reformate: :00 RON

Petroleum

Synthetic

Sub-Total

Reformate: 90 RON

Petroleum

Do Synthetic

Sub-Total

\section{C3/C4 Alkylate}

Butanes

Natural Gasoline

Methanol

Ethano1

MTBE

Synthetic Naphtha

Cat Gasoline: C5-250

Petroleum

Synthetic

Sub-Total

Cat. Gasoline: 250-410

Petroleum

Synthetic

Sub-Total

TOTAL VOLUME PERCENT
PETROLEUM

\begin{tabular}{cl}
1 & -6 \\
Base & Broadcut \\
\hline
\end{tabular}

10.8

21.1

0

21.1

\section{7}

¿8.2

0

$\tilde{2} 8.2$

21.1

0
21.1

28.2

0 .

10.0

10.0
7.0

9.9

0

0

0

0

6.8

0
6.8

13.3

13.3

$;$

10.0
SRALE OIL

Product Options

Gascline Supplements

\begin{tabular}{|c|c|c|c|c|c|c|}
\hline $\begin{array}{l}\text { ¿A } \\
\text { onven- } \\
\text { Lonal }\end{array}$ & $\begin{array}{l}\quad 3 \\
\text { Maximum } \\
\text { Diese1 }\end{array}$ & $\begin{array}{l}\quad 4 \\
\text { Broadcut } \\
\text { Fuel }\end{array}$ & Methanol & Ethanol & MTBE & $\begin{array}{l}11 \\
\text { Synthet } 1 \mathrm{c} \\
\text { Naphtha }\end{array}$ \\
\hline
\end{tabular}

tional Diese1

\section{(a)}

$\begin{array}{rcr}9.2 & 11.4 & 0.2 \\ 10.8 & 18.4 & 19.5 \\ 3.6 & 10.8 & 3.5 \\ 17.1 & 29.2 & 23.0\end{array}$

$$
0.1
$$

1.3

0.1

9.9

4.2

2.0

6.2

0
0
0

0

0
0
0

14.0

14.0

23.0

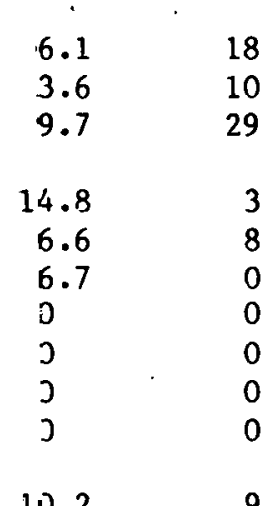

$\begin{array}{lc}18.5 & 19.6 \\ 10.8 & 3.5 \\ 29.3 & 23.1 \\ & \\ 3.2 & 3.7 \\ 8.4 & 7.9 \\ 0 & 16.7 \\ 0 & 0 \\ 0 & 0 \\ 0 & 0 \\ 0 & 0\end{array}$

16.1

16.123 .1

23.1
11.4

24.7

9.1

24.0

$34 \cdot 5$

15.2
39.9

5.9

15.0

11.1

0

1.2

10.0

10.0
0

0
0

9.6

4.1
13.7

9.1

10.2
5.2

15.4

13.8

13.8
6.2

20.0

3.4
5.7

5.7
0

0

10.0

10.0
0
0

.

$13.5 \quad 3.4$

?. 0

3.4
1.4

7.1

4.0

18.9

8.5

8.5
27.4

18.2

8.2
26.4

0.5
8.6

5.3

7.2

11.9

12.6

0

10.0

0

0

10.0

12.9

0

2.3

1.4

3.7

100.0

100.0

100.0

100.0

100.0

7.7

11.7

8.8

5.2

14.0

100.0 
TABLE 6.11

CRUDE

Case No.

Description

PREMIUM UNLEADED

Jight Straight Run

Reformate: 100 RON

Petroleum

Synthetic

Sub-Total

Reformate: 90 RON

Vै

Synthetic

Sub-Total

\section{C3/C4 Alkylate}

Butanes

Natural Gasoline

Methanol

Ethanol

MTBE

Synthetic Naphtha

Cat Gasoline: C5-250

Petroleum

Synthetic

Sub-Total

Cat. Gasoline: 250-410

Petroleum

Synthetic

Sub-Total

TOTAL VOLUME PERCENT
PREMIUM UNLEADED GASOLINE COMPOSITION

SHALE OIL CASES

ROCKY MOUNTAIN REGION

\section{PETROLEUM}

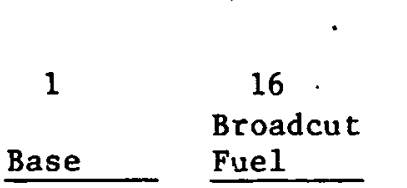

SHALE OIL

Product Options

2A

Conventional

5.7

3.5

5.1

23.2

22.3

0
22.3

0.

33.8

19.9

53.7

$\begin{array}{cc}22.3 & 23.2 \\ 0 & .0 .\end{array}$

22.3

23.2
.0
23.2

11.0

7.5

0 .

0

0

0

23.9

0

23.9

11.9

8.3

4.9

0

0

0

21.9$$
21.9
$$$$
21.9
$$

0
0
0

$$
\begin{array}{r}
6.6 \\
17.8
\end{array}
$$$$
\begin{array}{r}
11.2 \\
6.6
\end{array}
$$

0

8.1
13.6

0

0

0
0

7.3
0

\section{1}

0
3.1

5.3

$$
2.8
$$

8.1

100.0

17.6

7.7

0
0$$
\begin{aligned}
& 0 \\
& 0 \\
& 0
\end{aligned}
$$$$
\begin{aligned}
& 0 \\
& 0
\end{aligned}
$$

21.1

9.0

30.1

100.0

\begin{tabular}{ll}
\multicolumn{1}{c}{3} & \multicolumn{1}{c}{4} \\
Maximum & Broadcut \\
Diese1 & Fue1 \\
\hline
\end{tabular}

\begin{tabular}{cccc}
8 & 9 & 10 & $\begin{array}{c}11 \\
\text { Synthet1c } \\
\text { Naphtha }\end{array}$ \\
\hline
\end{tabular}

$\begin{array}{rr}1.0 & 3.9 \\ 11.3 & 12.4 \\ 6.6 & 2.2 \\ 17.9 & 14.6\end{array}$

0

21.5

10.6

32.1

$$
0.3
$$

9.7

0.7

0
0
0

8.7
5.4
14.1

13.6

0

22.3

12.5
2.2
14.7
18.5
6.8
0
0
0
0
0

21.6
10.6

10.6
32.2

40.2

19.8

60.0

8.8

8.8
5.4
14.2

0.

8.6
0
10.7
10.0
0
0
0

. 18.3

10.3

28.6

4.0
11.3
0.5
0
10.0
0
0

15.5

6.7

0
0

0

10.0

0

2.1

$$
0.6
$$

4.2

1.6

8.2

4.2

12.4

5.8

8.3
4.6

4.6
12.9

2.8

0.9

5.8

11.5

2.3

5.9

17.4

100.0

100.0
17.4

$100.0 \quad 100.0$

$$
\begin{aligned}
& 0 \\
& 0
\end{aligned}
$$

11.2

6.7

1.6

$$
0
$$$$
0
$$$$
10.0
$$

19.0

11.2

30.2

10.9

6.4

17.3

100.0 
TABLE 6.12

CRUDE

Case No.

Description

NO. 2 DIESEL FUEL

Treated Kero 400-550

$\stackrel{\infty}{\circ}$

NO. 2 DIESEL FUEL CONPOSITION

SHAIE OIL CASES

ROCKY MCUNTAIN REGION

\section{PETROLEUM}

\section{1}

Base
Petroleun

Syntheti:

Sub-Total

30.7

30.7

Treated Dist. 550-650

Petroleum

Synthetic

Sub-Total

Treated Lt. Cycle $0=1$

Hydrocracker Kero

TOTAL VOLUME PERCENT

$\begin{array}{cc}62.7 & 53.9 \\ 0 & 0 \\ 62.7 & 53.9 \\ & \\ 6.6 & 15.4 \\ 0 & 0\end{array}$

100.0

100.0

\section{7}

30.7

30.7

1.7

22.3

28.2

13.8

6.9

$15 \cdot 5$

1.4

21.2

22.6

0

18.8

1.2

21.6

1.1

42.0

29.5
46.7

27.8

30.2

58.0

30.9

46.7

30.6

46.8

77.4

34.5

46.7

81.2

30.5

46.7

77.2

0
0
0

100.
0
0

100.0
0

0

100.0

100.0
100.0

0
0

0

100.0

100.0 
TABLE 6.14 PREMIUM UNLEADED GASOLINE COMPOSITION

COAL OIL CASES

ROCKY MOUNTAIN REGION.

CRUDE

PETROLEUM

COAL OIL

Product 0 p I.ons

Case No.

Description

1

16

$5 \mathrm{~A}$

jB

6

$7 \mathrm{~A}$

Broadcut Conver-- Conven-

rional

Maximum

Broadcut

Base Fue 1

PREMIUM UNLEADED

Light Straight Run

Reformate: 100 RON

5.7

\author{
3.5
}

Petroleum

Synthetic

Sub-Total.

22.3

23.2

2.4

4.6

7.2

6.2

$15.1 \quad 24.4$

13.8

1). $\quad 00.2$

10.5

24.4
14.4

38.8

19.4

23.1)

25.6

3.1

12

12

13

Methanol

Ethanol

MTBE

14

$15 \mathrm{~A}$

Synthetic

Reformate: 90 RON

Petroleum
Synthetic
Sub-Total

\title{
C3/C4 Alkylate
}

Butanes

Natural Gasoline

Methanol

Ethanol

MTBE

Synthetic Nephtha

Cat Gasoline: C5-250

Petroleum

Synthetic

Sub-Tota1

$\begin{array}{ccc}22.3 & 23.2 & 9.6 \\ 0 & 0 & 6.4 \\ 2 \varepsilon .3 & 23.2 & 16.0 \\ 11.0 & 11.9 & 11.1 \\ 7.5 & 8.3 & 7.6 \\ 0 & 4.9 & 0 \\ 0 & 0 & 0 \\ 0 & 0 & 0 \\ 0 & 0 & 0 \\ 0 & 0 & 0\end{array}$

$\begin{array}{cc}15.1 & 24.4 \\ 13.5 & 14.4 \\ 25.6 & 38.8 \\ & \\ 5.8 & 4.4 \\ 3.3 & 10.8 \\ 0.9 & 0 \\ 0 & 0 \\ 0 & 0 \\ 0 & 0 \\ 0 & 0 \\ 23.0 & 0 \\ C & 0 \\ 23.0 & 0\end{array}$

\section{4}

3.1

22.5

17.8

8.7

0

0

0
0
0

$23.9 \quad 21.9$

0 1 0

29.7

0

0

15.8

0

15.8

5.1
21.6
14.0
35.6

$\begin{array}{rr}14.8 & 5.2 \\ & \\ 17.5 & 12.2 \\ 12.6 & 8.8 \\ 30.1 & 21.0\end{array}$

Cat. Gasoline: $250-410$

Petroleum

Synthetic

Sub-Total

$\begin{array}{lll}7.3 & 3.1 & 10.2\end{array}$

$\begin{array}{lll}7.3 & 3 & 0 \\ 0 & 3 & 10.2\end{array}$

$\begin{array}{ll}6.2 & 0 \\ 0 . & 0 \\ 6.2 & 0\end{array}$

6.5
0
6.5

\section{6}

14.0

35.6

6.2

17.5

12.6

30.1

12.2

1.7

2.9

10.0

0

0
0

3.8

0

10.4

$$
0
$$

12.4
4.0
0
0
10.0
0
0

0

5.3
0

0

0

10.0

0

23.2

3.8

0

23.2

$100.0 \quad \geqq 00.0$

100.0

$\begin{array}{lc}5.3 & 30.9 \\ 0 & 0 \\ 5.3 & 30.9\end{array}$

5.9

0

5.9

100.0

100.0

100.0

100.0

(1) 
TABLE 6.15 NO. 2 DIESEL FUEL COMPOSITION

COAL OIL CASES

ROCKY MOUNTAIN REGION

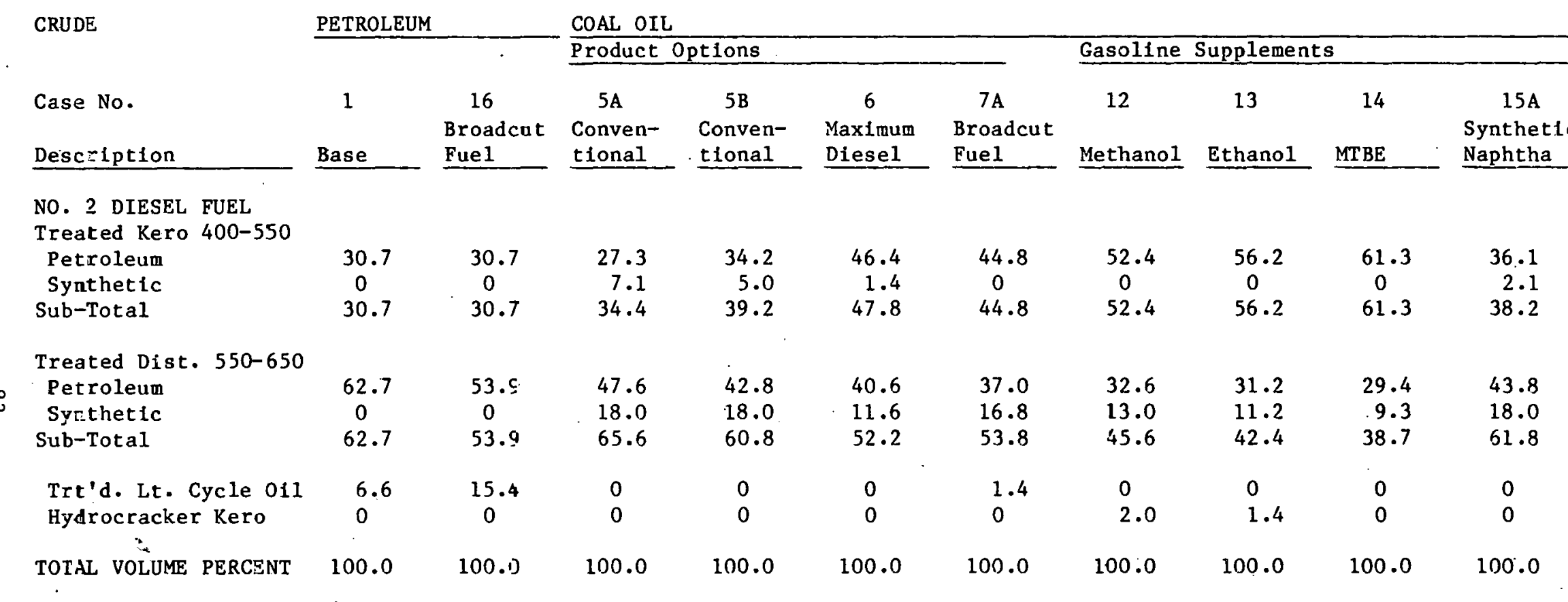


TABLE 6.16 REGULAR UNLEADED GASOLINE COMPOSITION SHALE AND CSAL OIL CASES

MID-CONTINENT AND GREAT ANKES RE3IONS

\section{REGION \\ CRUDE}

Case No.

REGULAR UNLEADED

Light Straight Run

Reformate: 100 RO:N

Petroleum

Synthet1c

Sub-Total

$\stackrel{\infty}{+}$
Description

MID-CONTINENT

PETROLEUM

SHALE AND DOAL OILS

\begin{tabular}{cl}
1 & \multicolumn{1}{c}{5} \\
Base & Broac̈cut \\
& Fle 1 \\
\hline
\end{tabular}

2
Conver-

\begin{tabular}{ll}
\begin{tabular}{cc}
\multicolumn{1}{c}{4} \\
Mazimum
\end{tabular} & Broadcut \\
Diesel & Fuel \\
\cline { 3 - 3 }
\end{tabular}

tional

$\begin{array}{ccrrr}14.5 & 10.3 & 11.9 & 15.5 & 11.6 \\ 25.6 & 13.5 & 15.7 & 16.7 & 14.7 \\ 0 & 0 & 6.1 & 9.0 & 5.3 \\ 26.6 & 13.5 & 21.8 & 25.7 & 20.0\end{array}$

$5.0 \quad-3.7$

c. 0

$5.0 \quad 13 . \bar{T}$

$$
15.0
$$

5.9

16.7

9.0

14.7

5.3

C3/C4 Alkylate

Butanes

Natural Gasoline

Cat Gasoline: C5-250

Petroleum

Synthetic

Sub-Total

11.

11.8
7.3

14.9

8.1

10.5

8.8

25.7

20.0

12.9
$i .5$

12.7

0

14.4

14.4

0

c

13.2
7.8
0

0

0

7.4

a

6.8

14.4

6.8

0

12.6

Cat. Gasol1 ne: 250-410

Petroleum

Synthetic

Sub-Total

$\begin{array}{cc}22.1 & 25.0 \\ .0 & 0\end{array}$

9.9

8.8

0

14.8

22.1

25.0

18.7

5.9

14.8

TOTAL VOLUME PERCENT

100.0

$100.0 \quad 100.0$
GREAT LAKES PETROLEUM

SHALE AND COAL OILS

\begin{tabular}{cl}
1 & \multicolumn{1}{c}{5} \\
Base & $\begin{array}{c}\text { Broadcut } \\
\text { Zuel }\end{array}$ \\
\hline
\end{tabular}

2

Conventional

3

Maximum

Diese1

?uel

$\begin{array}{clrrr}12.7 & 0 & 16.7 & 12.5 & 3.3 \\ 22.9 & 8.1 & 21.5 & 27.0 & 7.9 \\ 0 & 0 & 5.1 & 3.1 & 1.1 \\ 22.9 & 8.1 & 26.6 & 30.1 & 9.0\end{array}$

$\begin{array}{lcrrr}9.3 & 17.7 & 9.2 & 25.2 & 23.1 \\ 0 & 0 & 2.2 & 3.1 & 3.3 \\ 9.3 & 17.7 & 11.4 & 28.3 & 26.4 \\ & & & & \\ 11.4 & 19.5 & 12.4 & 9.9 & 17.6 \\ 7.9 & 7.6 & 7.8 & 8.0 & 7.3 \\ 0 & 0 & 0 & 0 & 0 \\ 14.8 & 30.5 & 6.1 & 10.2 & 23.4 \\ 0 & 0 & 0.6 & 1.0 & 5.0 \\ 14.8 & 30.5 & 6.7 & 11.2 & 28.4\end{array}$

$21.0 \quad 16.6 \quad 15.4 .0$

$\begin{array}{cccc}21.0 & 16.6 & 15.4 & 0 \\ 0 & 0 & 3.0 & 0\end{array}$

8.0

21.0

16.6

18.4

0

8.0

$100.0 \quad 100.0$

100.0

100.0

100.0 
TABLE 6.17. PREMIUM UNLEADED GASOLINE COMPOSITION

SHALE AND CCAL OIL CASES

MID-CONTINENT AND GREAT LAKES REGIONS

REGION

CRUDE

Sase No.

Description

PREMIUM UNLEADED

Light Straight Run

Reformate: 100 RON

Petroleum

Synthetic

Sub-Total

Reformate: 90 RON

$\infty$

etroleun

Synthetic

sub-Total

\section{C3/C4 Alkylate}

Butanes

Natural Gasoline

Cat Gasoline: C $5-250$

Petroleum

Synthetic

Sub-Total

Cat. Gasoline: 250-410

Petroleum

Synthetic

Sub-Total

TOTAL VOLUME PERCENT
MID-CONTINENT

PETROLEUM

SHALE AND COAL OILS

\begin{tabular}{cl}
1 & \multicolumn{1}{c}{5} \\
Base & Broadcut \\
\hline
\end{tabular}

2

Conven-

3

Diese1

tent

\begin{tabular}{ccccr}
1.8 & 0 & 0 & 0.7 & \multicolumn{1}{c}{0} \\
27.2 & 26.0 & 21.5 & 20.2 & 18.3 \\
0 & 0 & 8.3 & 10.9 & 6.6 \\
27.2 & 26.0 & 29.8 & 31.1 & 24.9
\end{tabular}

25.425.

$\begin{array}{cr}0 & 0 \\ 25.4 & 25\end{array}$

$12.0 \quad 12$.

$\begin{array}{ll}9.3 & 9.4 \\ 0 & 0\end{array}$

$18.5 \quad 20$.

$0 \quad \cdots 0 .$.

18.5

20.3

$5.8 \quad 5.9$

$0 \quad \cdots \quad 0$

$5.8 \quad 5.9$

$100.0 \cdot 100.0$

5.9

$\begin{array}{rcc}14.0 & 12.3 & 18.4 \\ 5.5 & 6.7 & 6.6 \\ 19.5 & 19.0 & 25.0 \\ 10.6 & 7.9 & 12.8 \\ 8.9 & 8.7 & 9.7 \\ 0 & 0 & 0 \\ 24.8 & 26.1 & 0 \\ 0 & 0 & 18.6 \\ 24.8 & .26 .1 & 18.6\end{array}$

$\begin{array}{ll}6.4 & : \\ 0 & 6.5 \\ 6.4 & 0 \\ & 6.5\end{array}$

0.7

8.3

100.0

100.0

100.0

GREAT LAKES

PETROLEUM

SHALE AND COAL OILS

\begin{tabular}{ccccc}
1 & 5 & 2 & 3 & 4 \\
Base & Broadcut & Conven- & Maximum & Broadcut \\
\hline
\end{tabular}

\section{1}

$\begin{array}{ll}11.1 & 13.4 \\ 49.7 & 30.6\end{array}$

49.7
0

30.6
0
30.6

0

0.7

11.8

49.7

30.6

32.6
7.7
40.3

37.7

24.6

4.0
41.7

3.5

28.1

$\begin{array}{cc}0 & 30.5 \\ 0 & 0 \\ 0 & 30.5 \\ 12.4 & 11.3 \\ 7.7 & 9.7 \\ 0 & 0 \\ 12.2 & 0 \\ 0 & 0 \\ 12.2 & 0\end{array}$

6.9

0

6.9
4.5

0

100.0

100.0

$\begin{array}{rrr}0 & 10.5 & 24.6 \\ 0 & 1.3 & 3.5 \\ 0 & 11.8 & 28.1 \\ 8.6 & 6.3 & 14.2 \\ 8.3 & 8.4 & 9.3 \\ 0 & 0 & 0 \\ 23.9 & 21.6 & 3.5 \\ 6.6 & 7.6 & 0 \\ 30.5 & 29.2 & 3.5\end{array}$

$\begin{array}{rll}9.6 & 1.9 & 5.0 \\ 2.7 & 0 & 0 \\ 12.3 & 1.9 & 5.0\end{array}$


TABLE 6.18 ND. 2 DIESEL FUEL COMPOSITION

S.IALE AND COAL OIL CASES

MID-CONTIIENT AND GREAT LAKES FEGIONS

REGION

CRUDE

Case No.

Description

NO. 2 DIESEL FUEL

Treated Kero 400-550

Petroleun

Syntheti:

Sub-Total

Treated D1st. 550-650

$\stackrel{\infty}{a}$

Petroleum

Synthetic

Sub-Total

Trt'd. Lt. Cycle 011

Hydrocracker Kero

MID-CCNTI NENT

PETROLEUM

SHALE ANI COAL OILS

1

Base

34.7
0
34.7

$$
\begin{gathered}
40.9 \\
0 \\
40.9
\end{gathered}
$$$$
\begin{array}{r}
34.2 \\
6.8
\end{array}
$$$$
\begin{array}{r}
49.7 \\
2.8
\end{array}
$$$$
41.0
$$$$
52.5
$$$$
\begin{gathered}
60.3 \\
0 \\
60.3
\end{gathered}
$$

38.0

$$
38.0
$$$$
24.8
$$$$
18.3
$$$$
17.4
$$$$
42.2
$$$$
12.4
$$$$
38.0
$$$$
56.3
$$$$
21.1
$$$$
2.7
$$

4.3

1.0

32.2

7.5

20.7
0$$
0
$$

100.0

100.0

100.0
GREAT LARES PETROLEU.

SHALE AND COAL OILS

1

Base

48

48.3
0
48.3

45.9
0
45.9
5.8
0

6

35
0
35
61
6
61
2
0
100

\begin{tabular}{l}
5 \\
Broatcut \\
Fuel \\
\hline
\end{tabular}

2

Conven-

\section{3}

Maximum

Diese1

Diese1

4

\begin{tabular}{l}
$\quad 4$ \\
Broadcut \\
Fuel \\
\hline
\end{tabular}


TABLE 6.19

REGION

CRUDE

Case No.

BROADCUT FUEL

Light Straight Run

145-400 Naphtha

Petroleum

Synthetic

Sub-Total

400-550 Kero

Petroleum

Synthetic

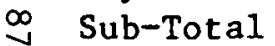

.550-650 Dist

Petroleum

Synthetic

Sub-Total

Lt. Cycle 0 il

CS-400 Visb Gaso

$\mathrm{N}$-Butane

TOTAL VOLUME PERCENT
BROADCUT FUEL COMPOSITION

SHALE AND COAL OIL CASES

ALL REGIONS

ROCKY MOUNTAIN

PETROLEUM

SHALE

COAI

MID CONTINENT

PETROLEUM

SHALE \& COAL

GREAT LAKES

16

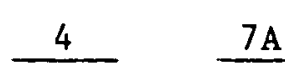

5

$48 \cdot 7$

35.0

39.9

17.3

39.3

0

39.3

0

32.3

0

46.8

29.5

32.3

46.8

29.5

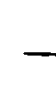

4

7.4

3.9

20.9

24.8

0

22.0

22.0

8.8

0
0

0

$\begin{array}{lll}4.8 & 10.3 & 23.2\end{array}$

$\begin{array}{lll}0 & 1.4 & 0\end{array}$

$\begin{array}{lll}4.8 & 11.7 & 23.2\end{array}$

9.5

8.9

18.4

16.6

0.9

9.9

3.1

$0.4 \quad 19.8$

$0 \quad 2.6$

0

100.0

100.0

$100.0 \quad 100.0$

100.0
SHALE \& OIL

4

19.7

26.2

15.8

42.0

0

13.6

13.6

4.5

6.0

10.5

0

7.8

6.4

100.0

100.0 
TABLE 6.20

RANGES IN FUEL COMPOSIZIONS

ROCKY MOUNTAIN EEGIOIJ

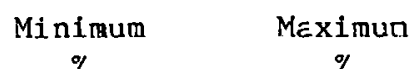

REGULAR UNLEADED

Light straight Run

Reformate: 100 RCN

Petroleum

Synthetic

Reformate: $90 \mathrm{RON}$

Petroleum

Synthatic

C3/C4 Alkylate

Butanes

Natural Gasoline

Methanol

Ethanol

MTBE

Synthetic Naphtha

Cat Gasoline: C5-250

Petroleur

Synthetic

Cat Gasoline: 250-410

Petraleum

Synthetic

NO. 2 DIESE: FUE:

Trt'd Kero 400-55:0

Petrcileum

Synthetic

Trt'd Dist 550-650

Petroleum

Synthetic

Trt'd Lt. Cycle Mil

Hydrocracker Kero
0

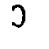

5.0

0

0.5

0

0

0

0

0

0

0

$\begin{array}{ll} & \\ 0 & 61.5 \\ \text { a } & 22.0 \\ 12.4 & 62.7 \\ C & 46.8 \\ \text { C. } & 15.5 \\ \text { C. } & 2.0\end{array}$$$
\%
$$

Minimum

$\%$

PREMIUM UNLEADED

16.7

Light Straight Run

Reformate: 100 RON

Petroleun

Synthetic

Reformate: 90 RON

Petroleum

Synthetic

C3/C4 Alkylate

Butanes

Natural Gasoline

Methanol

Ethanol

MT BE

Synthetic Naphtha

Cat Gasoline: C5-250

Petroleum

Syntheti:

Cat Gasoline: 250-410

Petroleum

Synthetic

BROADCUT FUEL

Light Straight Run

48.7

550-650 SR. Dist

Petroleum

23.2

Synthetic

46.8

145-400 Naphtha

Petroleum

39.3

Synthetic

46.8

9.9

19.8

Lt. Cycle 0 il

C5-400 Visb Gaso

400-550 SR Kero

Synthetic

Petroleum 
these components are reformate and catalytic gasoline. Other components would be essentially identical from any source. In diesel fuels straight run kerosene and treated distillate are separated into synthetic and petroleum sources. Products from catalytic cracking or hydrocracking were not segregated and usually appear in low concentration in the syncrude cases.

Reformate is stated as amounts of two grades, 90 and 100 Research Octane Number (RON). In actual practice this component would be supplied at the weighted average octane. For example, equal portions of 90 and 100 RON would produce 95 RON.

The same composition data are shown graphically on Figure 6.1 through 6.10. These ten charts are arranged in the same sequence as the preceding tables.

To simplify the graphical representation and emphasize the synfuel components, reformate of both octanes was combined into a single bar. All catalytically cracked gasoline was also combined into a single component. In broadcut fuels, visbreaker gasoline was combined with heavy naphtha since both are normally charge stocks to reforming. Compositions from these tables and charts will be the basis for a range of blends to be selected for engine and laboratory testing in future phases of the project.

The Rocky Mountain cases were further examined to trace the presence of synthetics in the transportation fuels. The percentage of synthetic (either shale oil or coal oil) in the charge was calculated for a rough comparison with the percentage of total synthetics in the transportation fuel blends. These calculations are summarized in Table 6.21. Shale oil concentration ranges from 32.7 to $35.8 \%$ of the feed. The average proportion of shale oil derived materials in the products are:

$\begin{array}{ll}\text { Regular Unleaded } & 27.5 \% \\ \text { Premium Unleaded } & 24.5 \% \\ \text { Diesel Fuel } & 53.7 \% \\ \text { Broadcut Fuel } & 53.5 \%\end{array}$

These results indicate that the shale oil compone,tis in the gasoline pool are about $70-80 \%$ of what would be expected based on synthetics in the feed. The high proportion of shale fractions in the diesel oil and broadcut fuel suggests that these components are advantageous in these products.

Reviewing Table 6.21 for the coal oil cases, concentration ranges from 22.6 to $24.8 \%$ of the feed. The average percentages of coal oil derived materials in the transportation fuels are:

$\begin{array}{ll}\text { Regular Unleaded } & 22.5 \% \\ \text { Premium Unleaded } & 23.0 \% \\ \text { Diesel Fuel } & 18.8 \% \\ \text { Broadcut Fuel } & 58.1 \%\end{array}$

These data suggest that the synthetics appearing in the gasoline pool are about what would be expected based on coal oil in the feed. The proportion of synthetics in diesel fuel is $70 \%$ of what would be expected and the synthetics in broadcut fuel is over twice what would be expected.

(Text continues on pg. 101) 
FIE 6.1 REGULAR UNLEADED COMPOSITION SHALE OIL CASES - ROCKY MOUNTAIN REgION

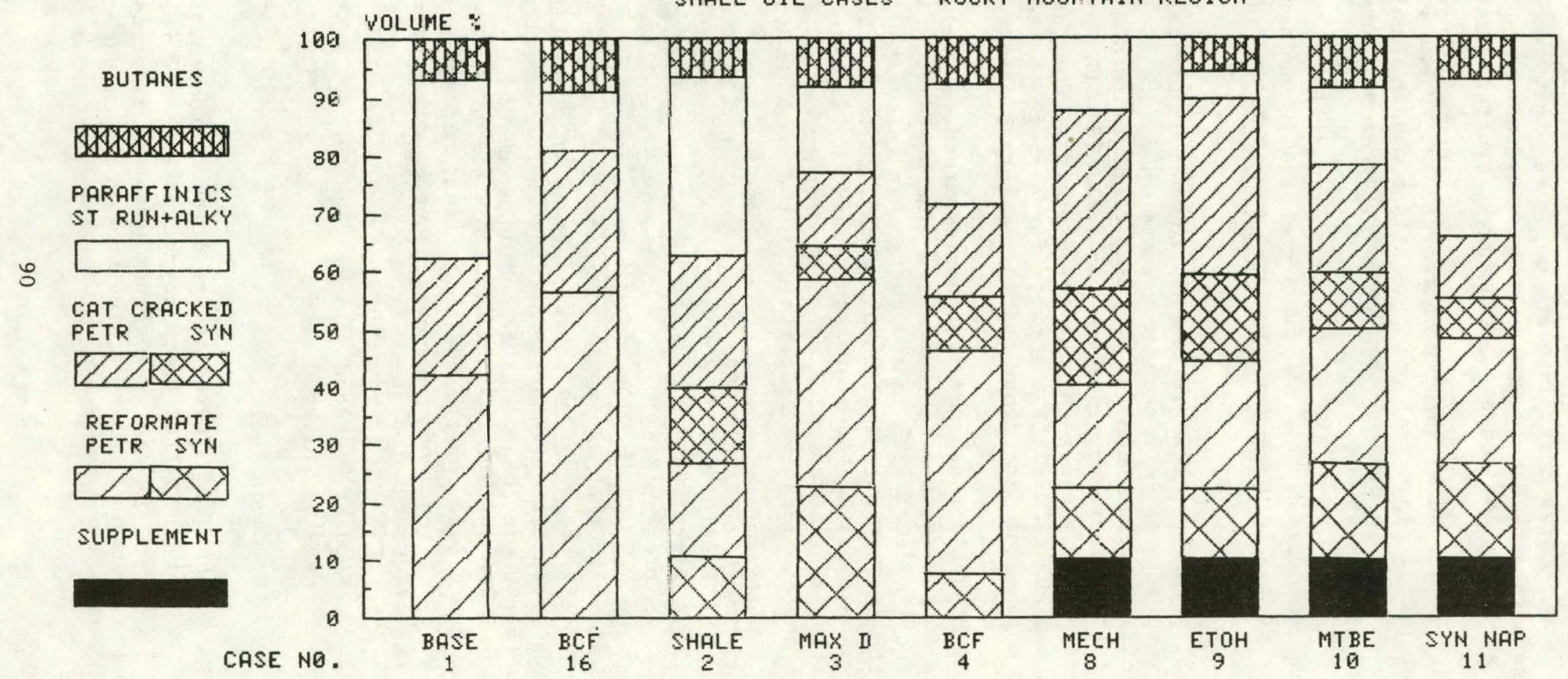




\section{FIE 6.2 PREMIUM UNLEADED COMPOSITION}

SHALE OIL CASES - ROCKY MOUNTAIN. REGION

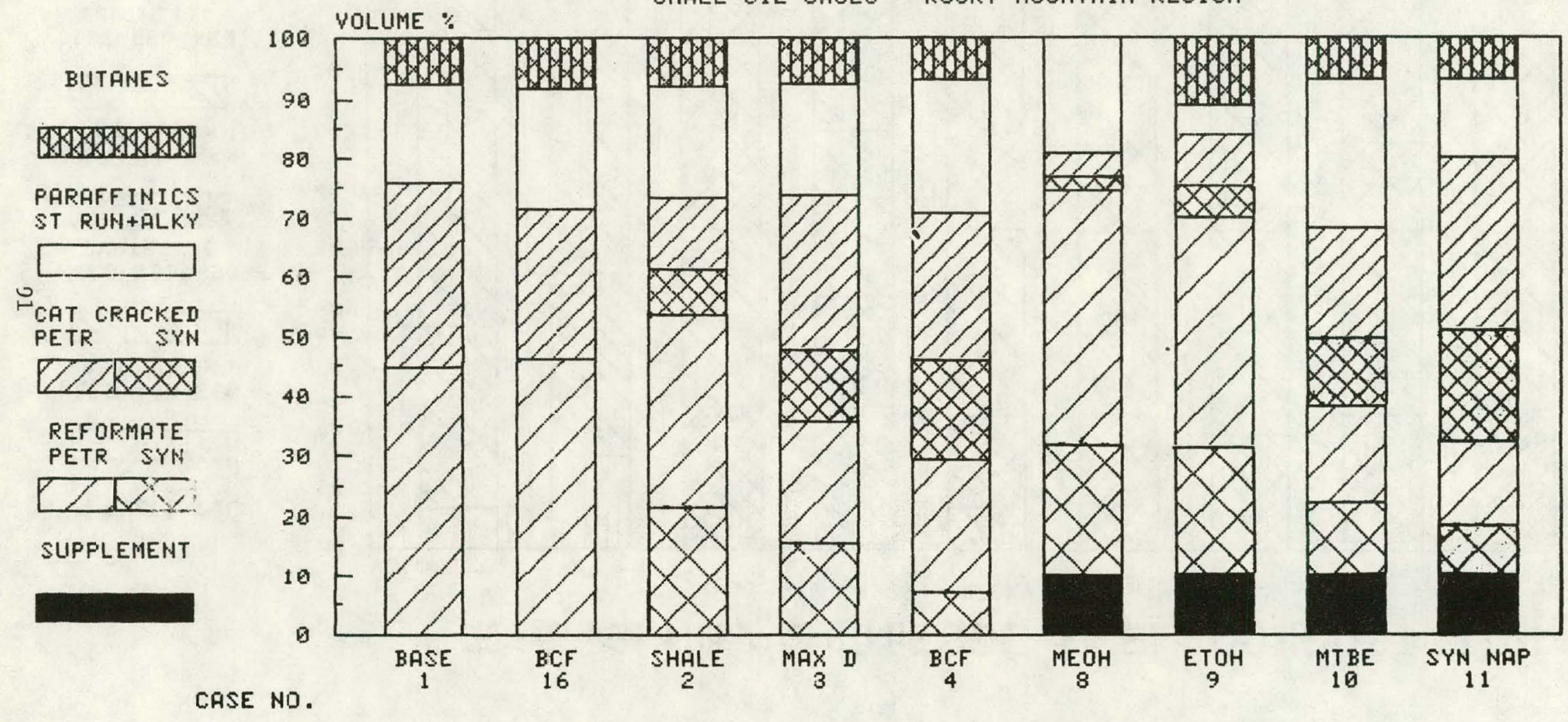


FIG 6.3 HQ. 2 DIESEL FUEL COMPOSITION

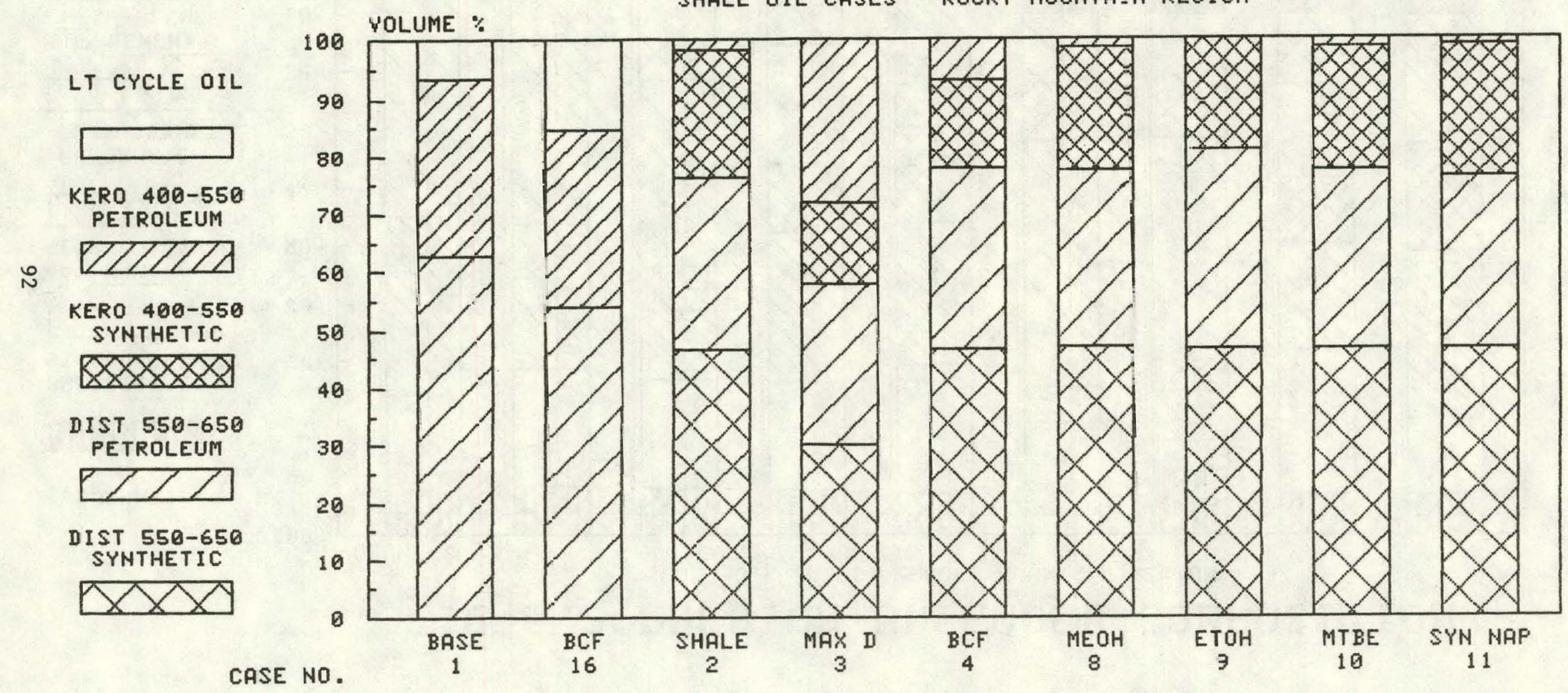


FIG 6.4 REGULAR UHLEADEI COMPOSITIOH COAL OIL CASES - ROCKY MOUNTAIN REGION

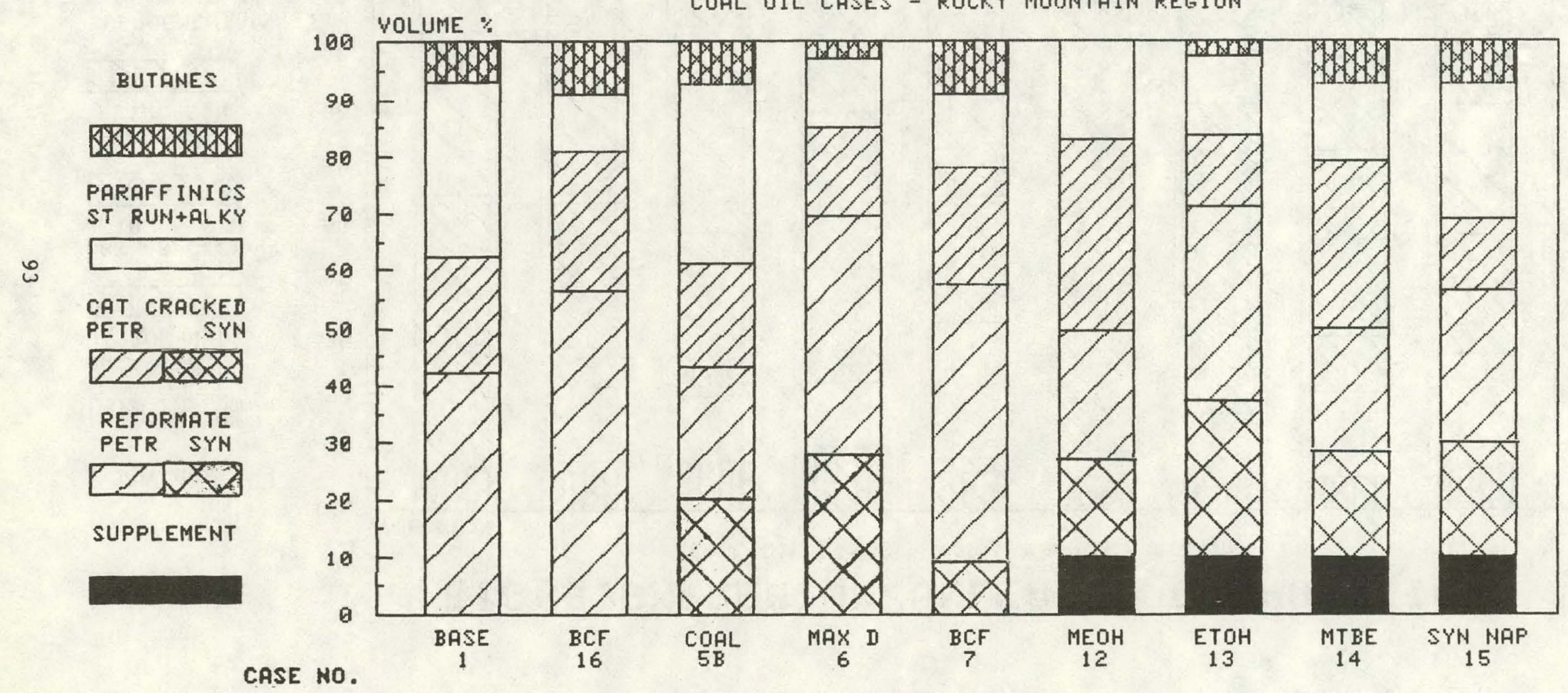




\section{FIG 6.5 PREMIUM UNLEADEI COMPOSITION}

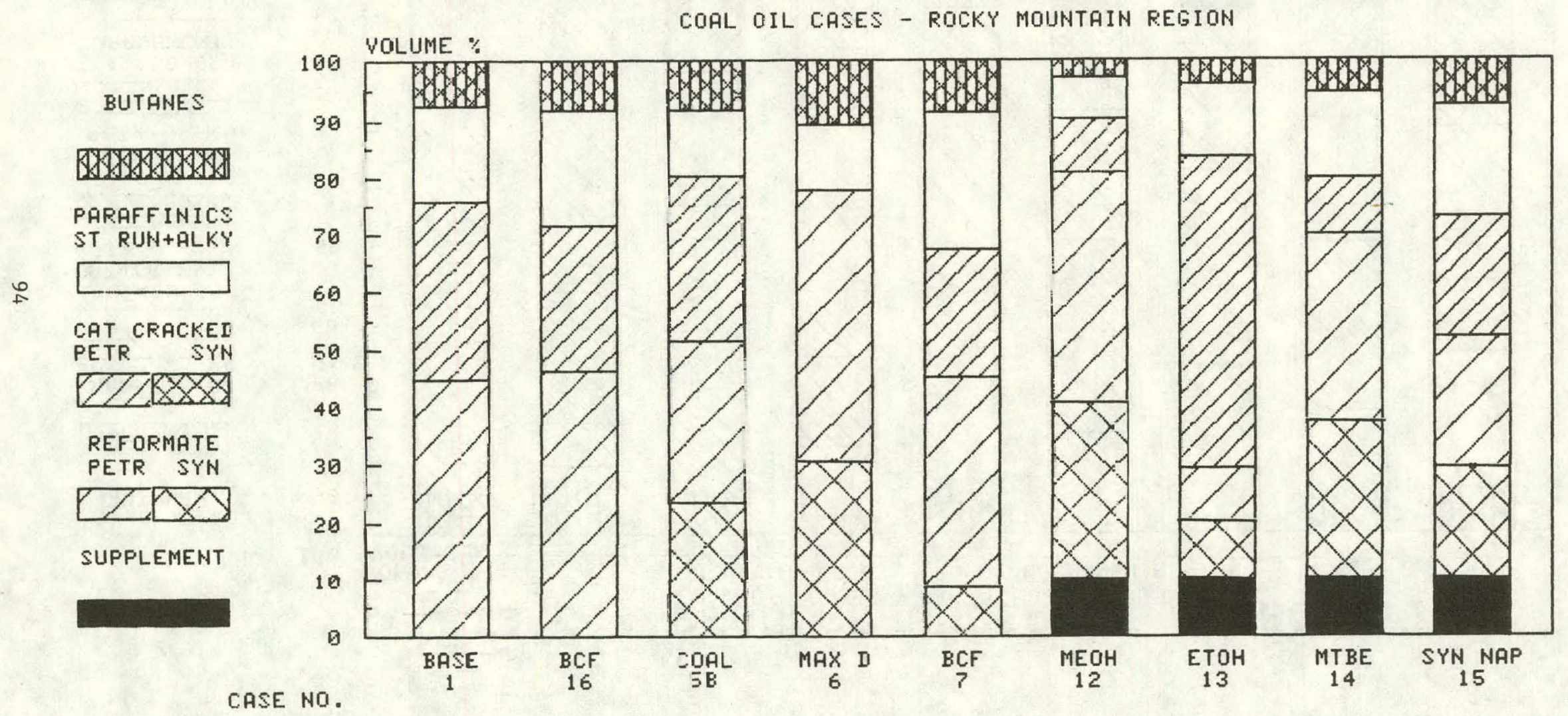


FIE 6.6 NO. 2 DIESEL FUEL COMPOSITION

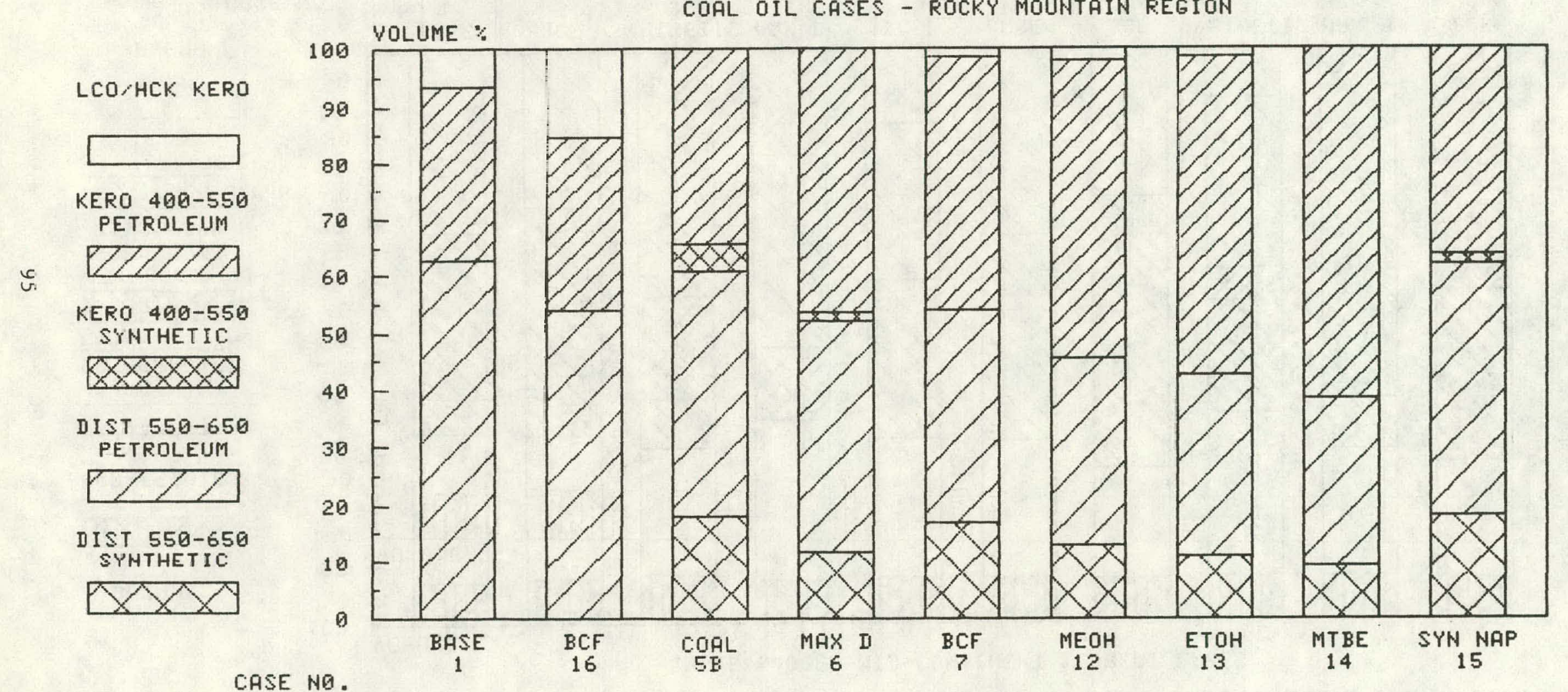


FIG 6.7 REGULAR UNLEADED COMPOSITION SHALE \& COAL-MID-CONTINENT \& GREAT LAKES

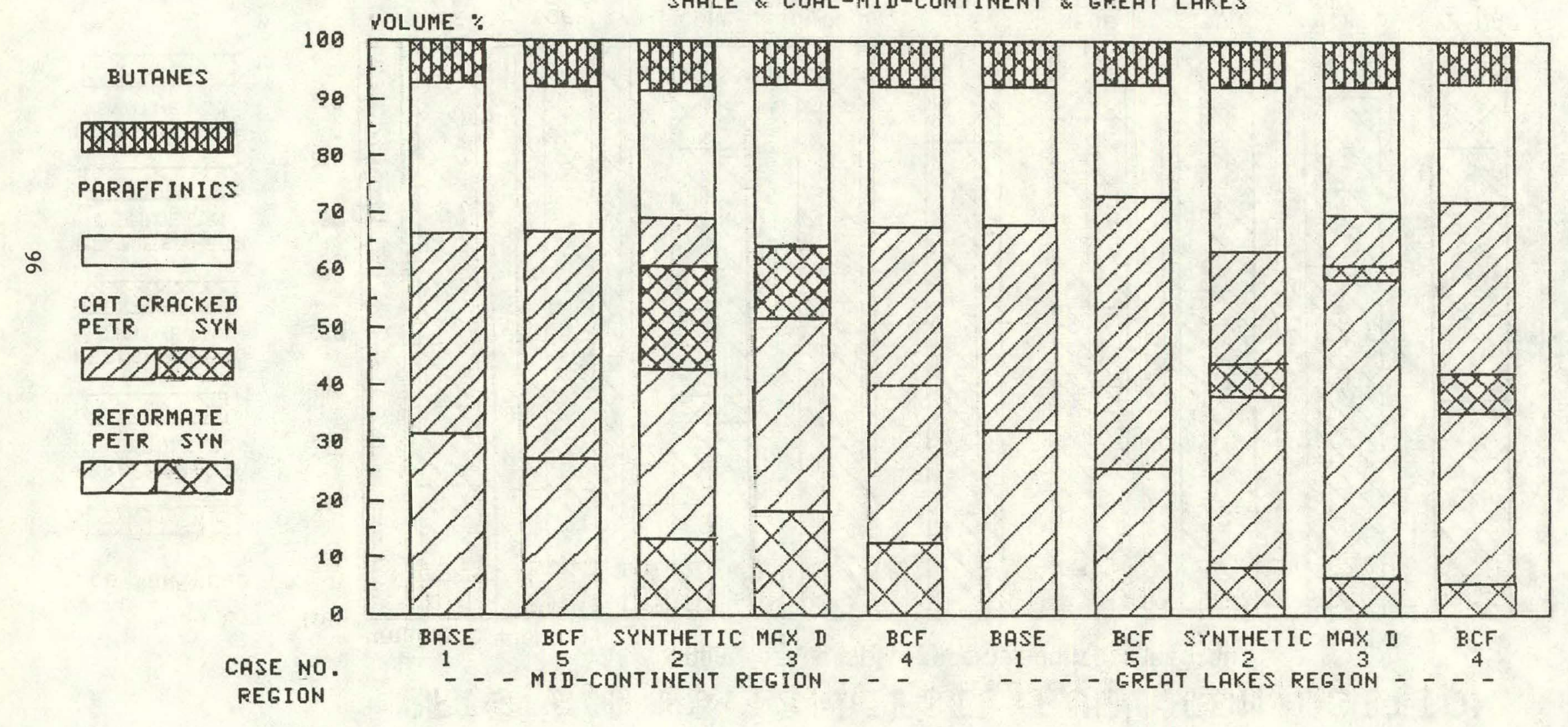


FIG 6.8 PREMIUM UHLEADED COMPOSITIOH SHALE \& COAL-MID-CONTINENT \& GREAT LAKES

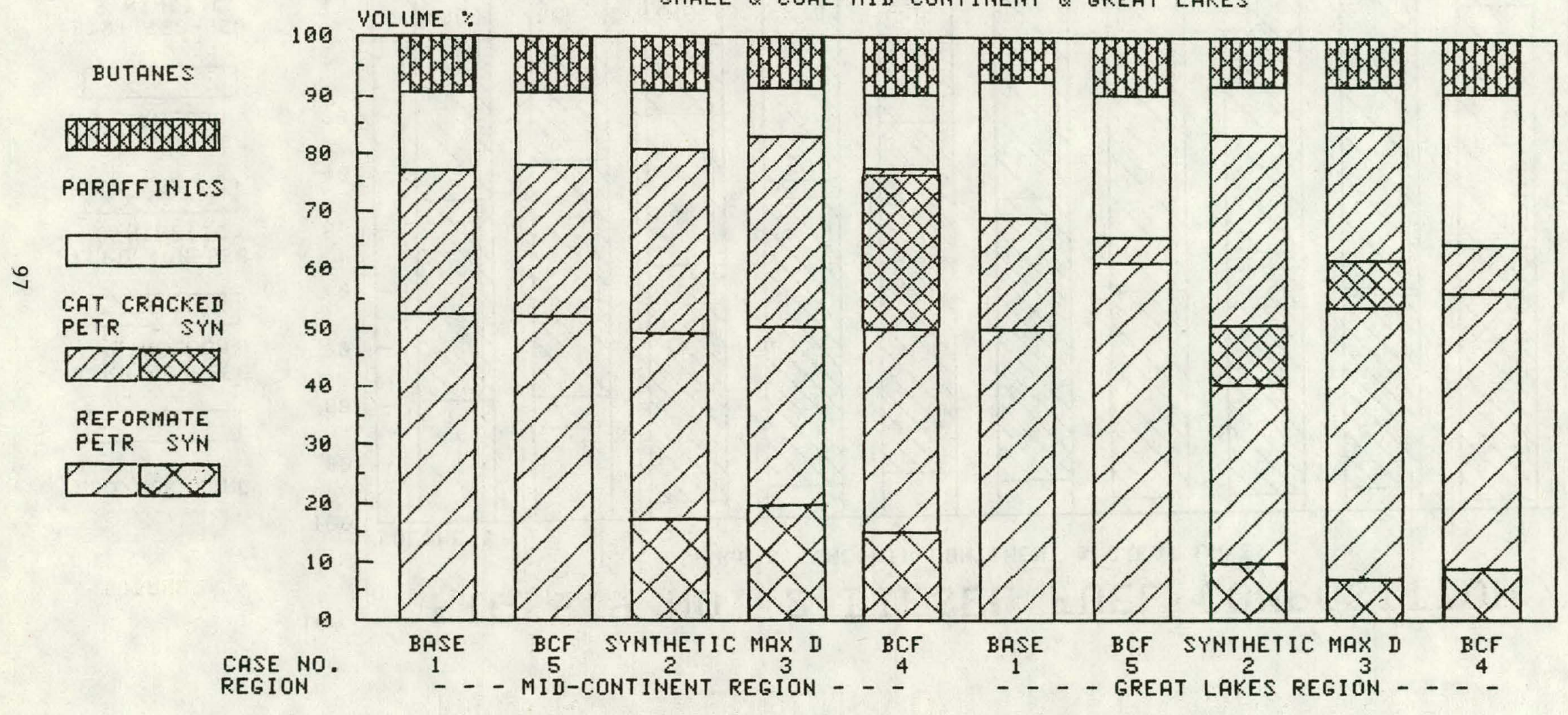


FIG 6.9 NO. 2 DIESEL FUEL COMPOSITION SHALE \& COAL-MID-CONTINENT \& GREAT LAKES

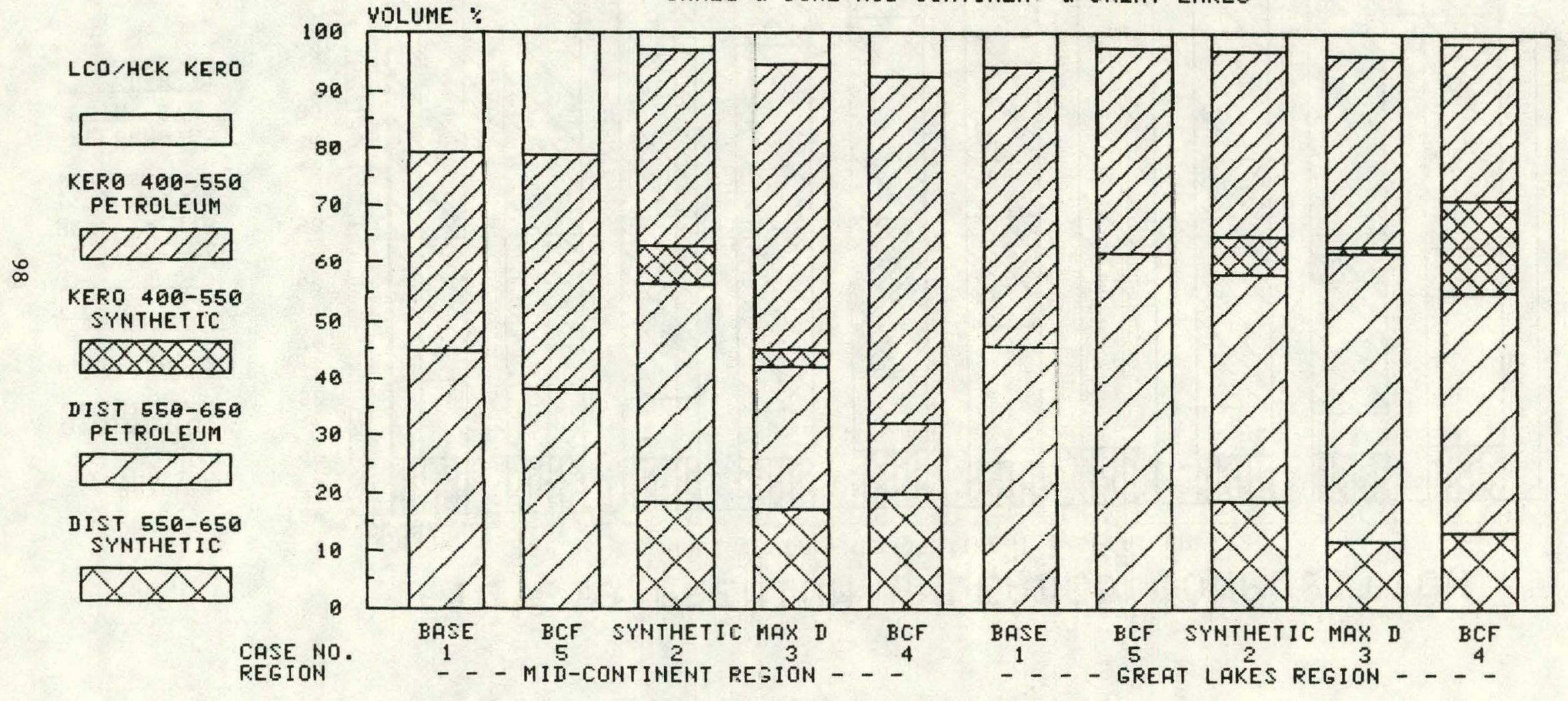


FIG 6.10 BROADCUT FUEL COMPOSITIONS SHALE AND COAL OIL CASES - ALL REgIONS

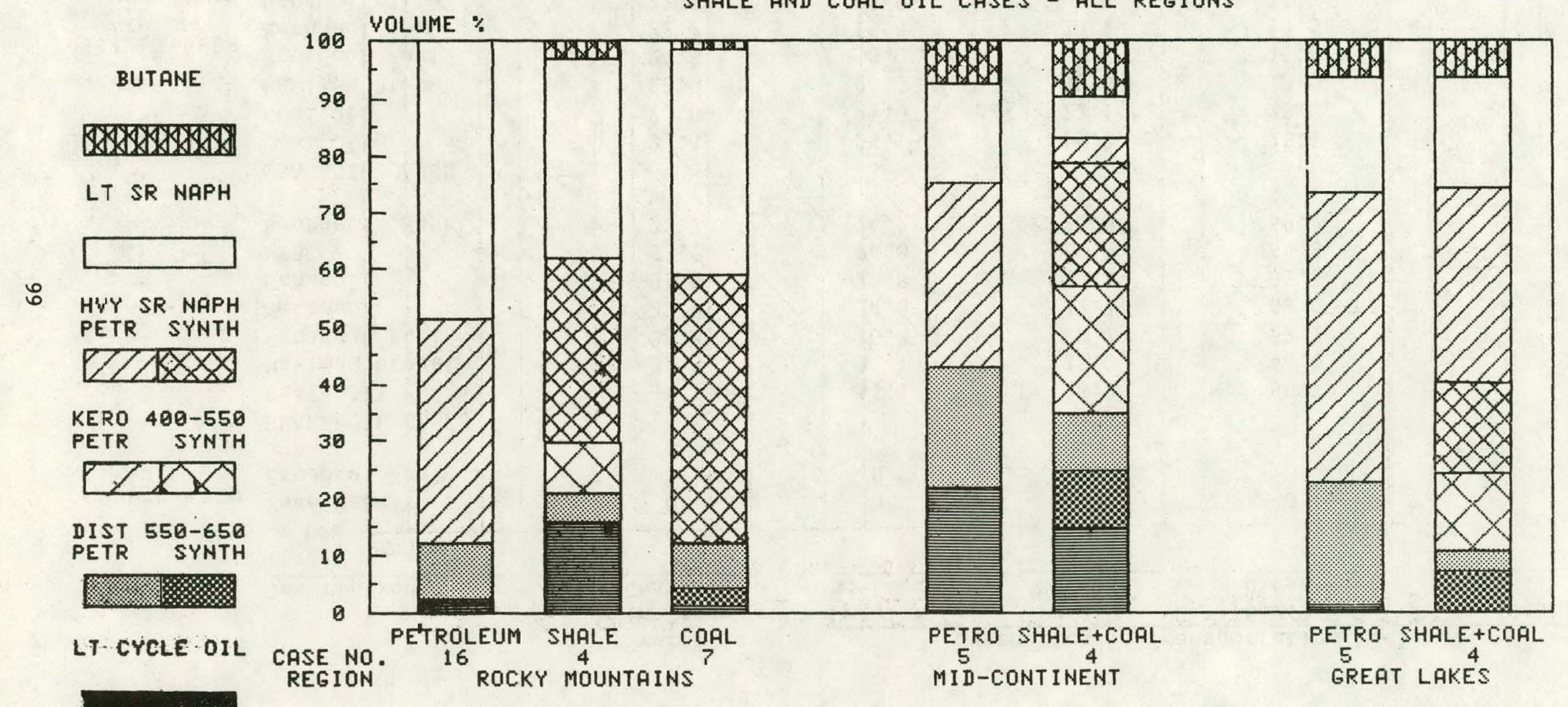


TABLE 6.21 OCCURENCE OF SYNTHETIC COMPONENTS IN TRANSPORTATION FUELS ROCKY MDUNTAIN REGION

Synthet:c

In Crude

Charge, \%

No.

Description

Base Case

Broadcut Fuel

SHALE OIL CASES

Shale oil

Maximun Diese1

Broadcut Fue1

Methanol

Ethano1

MTBE

Synthetic Naphtha

COAL OI

Coal Oil

Coal 0 il

Maximum Diese1

Broadcut Fue1

Methano:

Ethanol

MTBE

Synthetic Naphtha
0

0

34.1

35.3

35.8

32.9

33.5

33.9

32.7

23.4

23.8

23.0

24.8

22.7

22.9

22.9

22.6

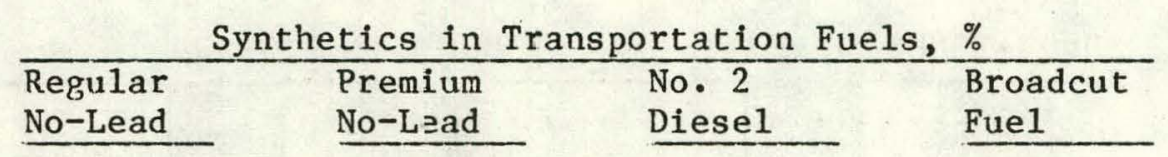

0$$
0
$$

0

0

0

0

0

45.1

31.1

16.3

24.6 .

25.8

24.8

24.7

28.3

25.0

20.7

22.7

23.8

24.2

26.5

68.7

44.0

62.2

68.0

65.5

68.3

69.2

22.1

21.0

28.1

8.0

15.5

24.9

16.8

21.1

16.2

25.1

23.0

13.0

16.8

13.0

11.2

29.2

7.9

28.5

18.8

20.1 
Coal ofl based derivatives are a larger portion of the gasoline pool than the shale oil components, primarily because of more gasoline components in coal liquids. This is not overcome by the fact that the vacuum gas oil from shale oil is charged to the catalytic cracker to make more gasoline while vacuum gas ofl from coal liquids goes to residual products rather than to gasoline via cracking.

\section{Raw Materials Effects}

The regional cases have been examined to determine the relative changes in petroleum raw materials requirements caused by introducing synthetics and gasoline supplements. The results of this analysis are shown in Tables 6.22 and 6.23. The differences in petroleum requirements were obtained by calculating differences in the petroleum consumption as defined by the following equation:

$\begin{aligned} \text { Petroleum Required }= & \text { Low-Sulfur Crude }+ \text { High-Sulfur Crude }+ \text { Butanes }+ \\ & \text { Natural Gasoline }- \text { LPG Product }+ \text { Purchased Fuel }\end{aligned}$

The product slate (except for LPG) was fixed in each run; LPG was allowed to vary. Therefore, in order to obtain the net differences in petroleum feedstock, the LPG output volumes had to be included. Purchased fuel in MMBTU/D was converted to Barrels Crude oil Equivalent (BCOE) by using a factor of $5.3 \mathrm{MMBTU} / \mathrm{BCOE}$.

Petroleum effects were calculated on a per-barrel basis. The comparisons between the base and synthetic cases used the volume of synthetic oil added. In the gasoline supplement cases, effect was calculated on a per barrel of supplement basis. For the synthetic naphtha case, the petroleum and fuel effects were reported on a per barrel of methanol basis, not per barrel of synthetic naphtha basis. Methanol yields about 42 volume percent naphtha (or about 54 volume percent hydrocarbon products; including light ends); results relative to $4,770 \mathrm{~B} / \mathrm{D}$ synthetic naphtha would appear closer to ethanol and MTBE. For the maximum diesel fuel and broadcut fuel runs, the difference was based on changes in the volume of gasoline required.

Mode1 changes were made between the coal syncrude cases and the shale cases in the Rocky Mountains. Therefore, contrasts between the shale oll and coal oil cases must be limited. The petroleum and fuel efficiency values reported are more accurate for the shale cases than for the coal cases.

The introduction of synthetics into the Rocky Mountain Region caused a decrease in the petroleum-based raw materlals on nearly a one-to-one basis (Table 6.22). For each barrel of coal oil substituted, 1.03 barrels of petroleum were saved. Introducing one barrel of shale oil replaced 0.95 barrels of petroleuw.

The use of methanol, ethanol, MTBE, and synthetic naphtha additives also decreased petroleum requirements. The use of supplements was set at 10 percent by volume in each grade. Ethanol and MTBE were the most efficlent, saving over one barrel of petroleum per barrel of supplement. 
TABLE 6.22 RAW MATERIAL EFFECTS

ROCKY MOUNTAIN REGION

CASE COMPARISON

Base (1) Coal (5B)*
Base (1) Shale (2A)
Base (1) BCF (16)
COAL CASES
Coal (5B) Max Diesel (6)
Coal (5B) BCF (7A)
Coal (5A) MEOH (12)
Coal (5A) E'HH (13)
Coal (5A) MTBE (14)
Coal (5A) SYN NAP (15A)
Coal (5B) SYN NAP (15A)
SHALE CASES
Shale (2A) Max Diese1 (3)
Shalc (2A) BGF (4)
Shale (2A) MEOH (8)
Shale (2A) ETOH (9)
Shale (2A) MTBE (10)
Shale (2A) SYN NAP (11)

INCREMENTAL BARRELS/DAY

PETROLEUM BARRELS/

INCREMENTAL BARREL
42,000 Shale $011 \quad-0.95$

19,100 Gasoline $\quad . \quad-0.22$.

14,300 Gasuline $\quad-0.23$

19,100 Gasoline $\quad-0.23$

4,770 Methanol -0.83

4,770 Ethano1 -1.01

4,770 MTBE $\quad-1.16$

11,475 Methanol $\quad-0.58$

11,475 Methano1 $\quad-0.56$

14,300 Gasoline $\quad-0.30$

19,100 Gasullite $\quad=0.22$

4,770 Methanol $\quad-0.96$

4,770 Ethanol -1.21

4,770 MTBE $\quad-1.19$

11,475 Methanol $\quad-0.56$

* The terms in parentheses refer to the individual computer run numbers. 
TABLE 6.23 RAW MATERIAL EFFECTS

MID-CONTINENT REGION

\section{CASE COMPARISON}

Base (1)

Syncrude (2)*

Syncrude (2) Max Diesel (3)

Syncrude (2) BCF (4)

Base (1)

BCF (5)

INCREMENTAL BARRELS/DAY

15,620 Coal \& Shale 011

7,794 Gasoline

10,392 Gasoline

10,392 Gasoline

$-0.21$

PETROLEUM BARRELS /

INCREMENTAL BARREL

$-0.97$

$-0.28$

$-0.23$

CREAT LAKES REGION

CASE COMPARISON

Base (1)

Syncrude (2)*

Syncrude

(2)

Max Diesel (3)

Syncrude (2) BCF (4)

Base (1) BCF (5)
INCREMENTAL BARRELS/DAY

16,130 Coal \& Shale 011

12,791 Gasoline

17,073 Gasoline

17,073 Gasoline
PETROLEUM BARRELS/ INCREMENTAL BARREL

$-1.02$

$-0.21$

$-0.21$

$-0.18$

\footnotetext{
* The terms in parentheses refer to the individual computer run numbers.
} 
Synthetic naphtha was the least effective of the supplements (in savings of petroleum feed), backing out 0.58 barrel of petroleum per barrel of feedstock. Methanol was intermediate, replacing 0.83 barrels of petroleum per barrel of supplement. These raw materials effects, however, do not include raw materials used in making the gasoline supplements.

The broadcut fuel and maximum diesel fuel raw material effectiveness was based on changes obtained per unit of gasoline demand reduction. The petroleum savings in both cases were 0.22 , and 0.30 barrels of petroleum per barrel of gasoline replaced. The raw material savings are the combined result of less processing and a reduction in product volumes because of better fuel economy for diesel and broadcut fuels.

The comparable analysis done for the Mid-Continent and Great Lakes Regions shows very similar results (Table 6.23). The introduction of a mixed syncrude containing coal ofl and shale oil caused a decrease in the petroleum consumption on nearly a one-to-one basis. The introduction of broadcut fuels caused a decrease in petroleum consumption of 0.18 to 0.23 barrels of petroleum per barrel of gasoline replaced. The decrease in petroleum consumption in the maximum diesel case was from 0.21 to 0.28 barrels of petroleum per barrel of gasoline.

\section{Energy Consumption Effects}

The regional cases were then examined to determine the changes in fuel requirements accompanying the introduction of syncrude into the typical refineries. The results of this analysis are reported in Tables 6.24 and 6.25. The total fuel requirements are based on differences in the total fuel requirements (as reported in Tables 6.4 through 6.6 ) in MMBTU per day. The total fuel requirement was defined by the following equation:

Total Fuel Required $=$ Plant Gas Fuel + Plant Liquid Fuel + Purchased Fue 1

The fuel effecte werc calculatcd on a per barrel Lasls wlll ratios simflar to the raw material effects above. Model changes were made between the coal cases and the shale cases in the Rocky Mountains. Therefore, contrasts between the shale and coal oil cases must be limited. The fuel efficiency values reported are more accurate for the shale cases than for the coal cases.

The shale oil case in the Rocky Mountain Region Indicated that fuel consumption increased 0.18 MMBTU per barrel of synthetic crude over the a11-petroleum base case (Tabje 6.24). The coal oil case showed 0.03 MMBtu per barrel increase in fuel consumption. This difference was due to the greater requirement for dcanlfuristion in the shale uil caee rclarlve to the coal oil case, as indicated in the comparison below:

\begin{tabular}{|c|c|c|c|}
\hline & $\begin{array}{l}\text { Base } \\
(1)\end{array}$ & $\begin{array}{l}\text { Shale oil } \\
\text { (2A) }\end{array}$ & $\begin{array}{l}\text { Coal oil } \\
(5 \mathrm{~B}) \\
\end{array}$ \\
\hline Synthetic Crude, B/D & 0 & 42,000 & 28,800 \\
\hline $\begin{array}{l}\text { Equivalent Light Distillate } \\
\text { Desulfurization, B/D }\end{array}$ & 21,524 & 98,287 & 37,608 \\
\hline Hydrogen Production, MSCF/D & 0 & 63,616 & 1,067 \\
\hline
\end{tabular}


TABLE 6.24 ENERGY CONSUMPTION EFFECTS

ROCKY MOUNTAIN REGION

ENERGY MMBTU/ CASE COMPARISON

Base (1) Coal (5B)*

Base (1) Shale (2A)

Base (1) BCF (16)

COAL CASES

Coal (5B) Max Diesel (6)

Coal (5B) BCF (7A)

Coal (5A) MEOH (12)

Coa1 (5A) ETOH (13)

Coal (5A) MTBE (14)

Coal (5A) SYN NAP (15A)

Coal (5B) SYN NAP (15A)

SHALE CASES

Shale (2A) Max Diesel (3)

Shale (2A) BCF (4)

Shale (2A) MEOH (8)

Shale (2A) ETOH (9)

Shale (2A) MTBE (10)

Shale (2A) SYN NAP (11)
INCREMENTAL BARRELS/DAY INCREMENTAL BARREL

$+0.03$

42,000 Shale $0 i 1 \quad+0.18$

19,100 Gasoline $\quad-0.24$

14,300 Gasoline $\quad+0.40$

19,100 Gasoline $\quad-0.25$

4,770 Ethanol $\quad-0.40$

4,770 MTBE $\quad-0.36$

11,475 Methano1 . . $\quad-0.01$

11,475 Methanol $\quad-0.15$

14,300 Gasoline $\quad-0.06$

19,100 Gasoline $\quad-0.34$

4,770 Methanol -0.23

4,770 Ethanol $\quad-1.77$

4,770 MTBE -1.03

11,475 Methanol $\quad-0.22$
4,770 Methanol $\quad-0.04$

ऋ The terms in parentheses refer to the individual computer run numbers. 
TABLE 6.25 ENERGY CONSUMPTION EFFECTS

MID-CONTINENT REGION

\section{CASE COMPARISON}

Base (1) Syncrude (2)*

Syncrude (2) Max Diesel (3)

Syncrude (2) BCF (4)

Base (1). BCF (5)

\section{INCREMENTAL BARRELS/DAY}

15,620 Coal \& Shale Oil

7,794 Gasoline

10,392 Gasoline

10,392 Gasoline

GREAT LAKES REGION
ENERGY MMBTU/

INCREMENTAL BARREL

$+0.13$

$-0.23$

$-0.36$

$-0.25$

CASE COMPARISON
Base (1)
Syncrude (2) Max Diese1 (3)
Syncrude (2) BCF (4)
Base (1) BCF (5)

INCREMENTAL BARRELS/DAY

ENERGI MMBTU/

16,130 Coal \& Shale 0il INCREMENTAL BARREL

12,791 Gasoline

$+0.09$

17,073 Gasoline

$-0.21$

17,073 Gasoline

$-0.30$

$-0.27$

* The terms in parentheses refer to the individual computer nun numbers. 
The increased charge required for hydrodesulfurization was based on the requirement that all shale oils must be hydrotreated before being charged to the crude unit. The only one of the three coal oils which was hydrotreated was the material from non-catalytic hydrogenation. The coal liquid from pyrolysis was assumed to be hydrogenated before shipment to the refinery. Also, a higher percentage of the shale underwent a second treating step. The shale vacuum gas olls were hydrotreated before being sent to the FCC unft, whereas the $650^{\circ} \mathrm{F}+$ fractions from coal syncrude went directly to residual fuel oils.

The fuel consumption in the Rocky Mountaln shale ofl case represented a 19 percent increase in total fuel consumption. Coal liquids in the same region required about 2 percent increase in fuel used, an indication of the smaller amount of processing given coal 1iquids.

All of the Rocky Mountain gasoline supplement cases showed fuel savings relative to their respective synthetic fuel base cases. The fuel savings for the shale oll cases appeared to be higher than those for the coal oil cases. MTBE and ethanol gave higher fuel savings than did methanol and synthetic naphtha. The synthetic naphtha cases included the utility requirements to produce the additive from a methanol feedstock. Although fuel savings were assoclated with the use of these products, the fuel requirements were not included in preparing each additive. Therefore, any conclusions relative to the overall energy efficiency of these additives would be Inappropriate.

Fuel efficiencles for the broadcut and maximum diesel cases were based on changes in refinery fuel used per unit of gasoline demand reduction. The Rocky Mountaln shale oll cases showed fuel savings through use of broadcut and diesel fuels. Savings ranged from 0.06 MMBTU per barrel in the maximum diesel fuel case to 0.34 MMBTU per barrel in the broadcut fuel case. These fuel savings equated to 0.01 to 0.06 barrels of petroleum per barrel of gasoline (based on 5.3 MMBTU per barrel of petroleum). Therefore, the energy savings were far less than the savings of 0.22 to 0.30 barrels of petroleum raw material per barrel of feed achieved through the product type shifts from gasoline to diesel and broadcut fuels.

The Rocky Mountain coal cases showed somewhat different results, espectally in the maximum diesel case. In this case fuel consumption actually increased. This increase may be parlially offset conoidering the large volume of LPG produced in this case ( 4514 barrels per day) relative to the coal ofl base case (1239 barrels per day). These cases also supported the conclusion that the refinery fuel savings in moving to substitute automotive fuels are not as significant as the petroleum raw material savings achieved via the shift in the product types.

The comparison between the base case and the broadcut fuel case with natural crudes Indicated an energy efficiency identical to that calculated for coal ofl case but somewhat lower than the shale ofl case.

The Mid-Continent and Great. Lakes Region cases showed results similar to the above findings (Table 6.25). The fuel consumptions increase when": changing to a syncrude slate from the base natural crude slate, +0.13 
MMBTU/barrel of syncrude in the Mid-Continent and $0.09 \mathrm{MMBTU} / \mathrm{barrel}$ of syncrude in the Great Lakes Region. The maximum diesel cases show decreasing fuel requirements of -0.21 to $-0.23 \mathrm{MMBTU} / \mathrm{barrel}$ of gasoline. The values for energy savings in these regions with mixed syncrudes are intermediate between the values from the Rocky Mountalns where coal ofl and shale oil has directionally different effects on fuel consumption in the maximum diesel fuel case.

The broadcut fuel cases are all guite similar in effect. The fuel savings are $-0.24 \mathrm{MMBTU} / \mathrm{barrel}$ of gasoline in the Rocky Mountains, -0.25 MMBTU/barrel in the Mid-Continent, and $-0.27 \mathrm{MMBTU} /$ barrel in the Great Lakes. The syncrude broadcut fuel cases show slightly higher fuel consumptions.

The conclusion is consistent in all regions that petroleum raw material savings are significant in shifting product demand patterns to other fuel types such as maximum diesel or a broadcut fuel. The refinery fuel savings which occur in the same product shift are measurable but minor in magnitude.

\section{E. Investment Effect.s}

The effect on lincremental investments required hy syncrudes and gacolinc supplements is shown in Tables 6.26 and 6.27 . The investment ratio represents the Investment required in the subject case, for example the coal case (5B) divided by the investment required in the base case (1). The investment required in the base case is chiefly in the crude unit and vacuum tower to allow for the overall demand increase. The coal ofl case (5B) includes. capability to process syncrude as well. The new facility requirements in barrels per stream day are shown in Tables $6.4,6.5$, and 6.6 .

The investment effects indicate that introducing syncrude will require a considerable level of additional investment. In the Rocky Mountain Region, shale ofl will require 2.71 times the investment while coal oil will require 1.10 times. In the Mid-Continent this ratio is 3.14 and in the Great Lakes Region the ratio is 2.24 for combined shale oil and coal o11. These additional investments are primarily a reflection of the increased requirement for hydrodesulfurization units and hydrogen production required by the syncrudes.

The broadcut fuel cases show lower investment requirements relative to thelr base cases. The petroleum crude broadcut fuel cases show lower investment requirements than their respective synthetic broadcut fuel cases. For example in the Mid-Continent Region, the synthetics broadcut fuel case shows an investment ratio of 0.76 compared to a 0.41 ratio for the petroleum broadcut case.

The maximum diesel fuel cases are less consiotent at firgt glance. In the Rocky Mountain Region, the investment ratios for coal oil and shale ofl cases are greater than 1.0, while for the Mid-Continent and Great Lakes $R \in z$ ions the investment ratios are 0.80 and 0.92 respectively. The difference may be explained by:

a. the higher proportion of syncrude in refinery charge in the Rocky Mountains requiring more hydrogenation and hydrogen generation factitties, 
INCREMENTAL BARRELS/DAY INVESTMENT RATIO**

Base (1) Coal (5B)*
Base (1) Shale (2A)
Base (1) BCF (16)
COAL CASES
Coal (5B) Max Diesel (6)
Coal (5B) BCF (7A)
Coal (5A) MEOH (12)
Coal (5A) ETOH (13)
Coal (5A) MTBE (14)
Coal (5A) SYN NAP (15A)
Coal (5B) SYN NAP (15A)
SHALE CASES
Shale (2A) Max Diesel (3)
Shale (2A) BCF (4)
Shale (2A) MEOH (8)
Shale (2A) ETOH (9)
Shale (2A) MTBE (10)
Shale (2A) SYN NAP (11)

28,800 Coal $0 i 1$

1.10

42,000 Shale $011 \quad 2.70$

19,100 Gasoline $\quad 0.76$

COAL CASES

Coal (5B) Max Diesel (6)

14,300 Gasoline

1.72

19,100 Gasoline

4,770 Methanol

0.81

4,770 Ethano1

0.99

4,770 MTBE

1.00

11,475 Methano1

1.04

11,475 Methano1

1.06

1.19

14,300 Gasoline $\quad 1.05$

19,100 Gasoline $\quad 0.94$

4,770 Methanol 1.03

4,770 Ethanol . 1.03

4,770 MTBE

0.96

11,475 Methanol 1.06

* The terms in parentheses refer to the individual computer run numbers.

** The ratio is the investinent for the second case listed divided by the first case on each line. 
CASE COMPARISON

Base (1) Syncrude (2)*

syncrude (2)

Syncrude (2) Max Diesel (3)

Syncrude (2) Broadcut (4)

Base (1)
INCREMENTAL BARRELS/DAY

15,620 Coal \& Shale 0il

7,794 Gasoline

10,392 Gasoline

10,392 Gasoline

GREAT LAKES REGION
INVESTMENT RATIO**

3.14

0.80

0.76

0.41
CASE COMPARISON

Base (1)

Syncrude

Syncrude (2)

Base (1)

Syncrude (2)

INCRFMFNTAL BARRELE/DAY

16,130 Coal \& Shale 011

12,791 Gasoline

17,073 Gasoline

17,073 Gasoline
INVESTMENT KATL

\subsection{4}

0.92

0.85

0.67

* The terms in parenthesis refer to the individual computer run numbers.

** The ratio is the investment for the second case listed divided hy the firot case on each line. 
b. higher diesel fuel production relative to gasoline in the Rocky Mountains, and

c. additional segregation of the hydrotreated kerosene and distillate fractions in the latter two regions which would introduce economic flexibility to the blending operation.

The gasoline supplement cases indicate little impact on investment compared to the amount for syncrude processing. These investments do not include the costs to prepare methanol, ethanol, or MTBE so this factor must be used in interpreting the results.

\section{F. Flowsheets}

For the determined reader, four tables provide material balances for synthetic crudes in each of the regional refineries. Each table has an accompanying flowsheet with all streams identified by name and number. Table and figure numbers are:

Table $\quad$ Figure

$6.28 \quad 6.11 \quad$ Shale 0il - Rocky Mountain

$6.29 \quad 6.12 \quad$ Coal 0il - Rocky Mountains

$6.30 \quad 6.13$ Shale Oil - Mid-Continent and Great Lakes

$6.31 \quad 6.14 \quad$ Coal Oil - Mid-Continent and Great Lakes

The tables show quantity of each stream in barrels per day ( $B / D)$. For instance, Table 6.28 shows $42,000 \mathrm{~B} / \mathrm{D}$ shale oil to the syncrude hydrotreater. This volume increases to $46,200 \mathrm{~B} / \mathrm{D}$ charge to the crude unit by addition of hydrogen. The crude unit separation into five streams is shown with their boiling range, e.g., Stream 3, Heavy naphtha, $145-400^{\circ} \mathrm{F}$. The 7392 $B / D$ of this stream goes to the naphtha hydrotreater in most cases. Its volume increases to $7466 \mathrm{~B} / \mathrm{D}$ by hydrotreating to stream 7 which is sent to catalytic reforming. In Case 4, however, $5339 \mathrm{~B} / \mathrm{D}$ bypassed the hydrotreater as stream $3 B$ and went to broadcut fuel.

Streams to blending with or without hydrotreating show on the flowsheets. Streams to conversion processes such as reforming, cracking and coking are shown but the conversion products do not appear. Those results can be inferred from product compositions on Table 6.10 through 6.19.

One difference between shale oils and coal oils processing is in the process path selected by the model for the $650^{\circ} \mathrm{F}$ and heavier reduced crude fraction. About half of the shale oil reduced crude is sent to a vacuum unit where it is fractionated into three streams: $650-700^{\circ} \mathrm{F}$ light vacuum gas oil, $700-930^{\circ} \mathrm{F}$ heavy vacuum gas oil, and $930^{\circ} \mathrm{F}+$ vacuum residual. The vacuum gas oils are desulfurized in a gas oil hydrotreater and then charged to the fluid catalytic cracker. The balance of shale oil $650^{\circ} \mathrm{F}+$ reduced crude is sent lo No. 6 fuel oil blending.

By contrast, coal oil reduced crude is sent directly to No. 6 fuel oll blending. One reason for this appears to be that the vacuum gas oil from coal liquids is an inferior catalytic cracker feedstock. The other reason is the low residual volume from the coal liquids and the need to make a glven volume of No. 6 fine1 nil. 
TABLE 5.28 SHAL 3 OIL PROCESSING ROCKY MOLUTAIN REGION

\begin{tabular}{l} 
Stream \\
Number \\
\hline \\
\\
1 \\
2 \\
3 \\
$3 \mathrm{~A}$ \\
$3 \mathrm{~B}$ \\
4 \\
$4 \mathrm{~A}$ \\
$4 \mathrm{~B}$ \\
5 \\
$5 \mathrm{~A}$ \\
$5 \mathrm{~B}$ \\
6 \\
\\
7 \\
8 \\
9 \\
10 \\
11 \\
12 \\
13 \\
14 \\
15 \\
$15 \mathrm{~A}$ \\
$15 \mathrm{~B}$ \\
$15 \mathrm{C}$ \\
16 \\
$16 \mathrm{~A}$ \\
$16 \mathrm{~B}$ \\
18 \\
19 \\
20 \\
21 \\
22 \\
23 \\
24 \\
25 \\
26 \\
\\
\\
\\
\\
\\
\end{tabular}

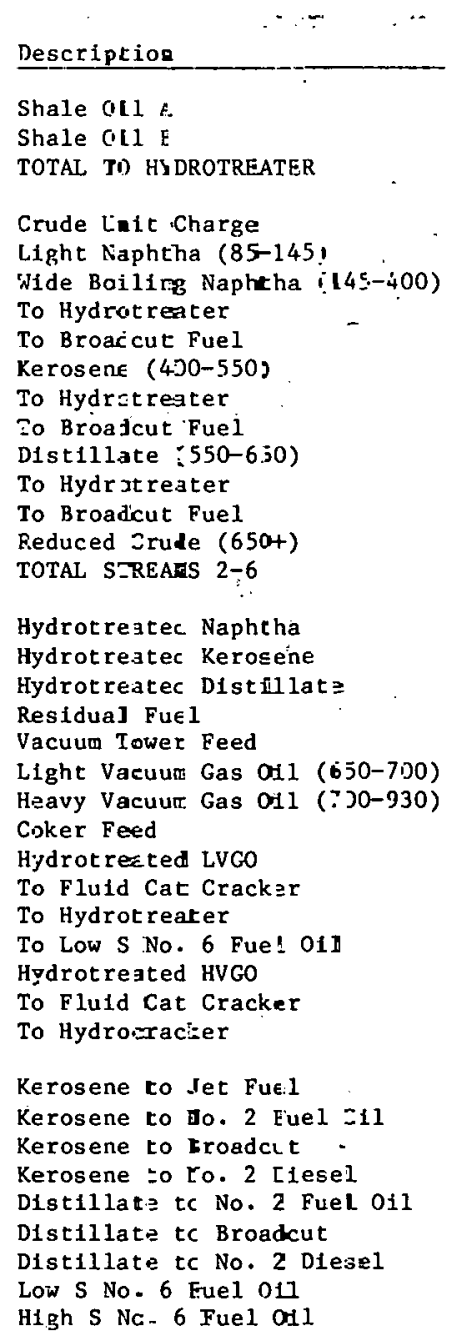

Pro-luct Opticrs

Conventzone

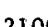

21000000

147.8
7392
7392

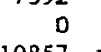

$1035 \%$
$1035 \%$

9243

9243

17239

46200 .

$7468 \quad 7466$

1085:

9060

$887 \epsilon$

1904
6901

71

1833
1833

1833
0

0.1
6562
6562

6562
0

4704

1881

0
4272
0

0
9060

7078
1279

7392

10357

0
$9: 40$

$9: 40$

0
$17 \geq 33$

$7 \leftarrow 66$
$10 \varepsilon 57$
$462 C 00 \quad 46200$

3

\begin{tabular}{c}
4 \\
Broadcut \\
\hline 21000 \\
21000 \\
42000
\end{tabular}

$\frac{\text { Gasoline Supplements }}{8}$

Methanol Ethanol 10

YTBE

11

$21090 \quad 21000 \quad 21000$

$\begin{array}{rrrr}21000 & 21030 & 21000 & 21000 \\ 42000 & .42030 & 42000 & 42000\end{array}$

42000

46200.46200

$\begin{array}{ll}1478 & 1478 \\ 7392 & 7392\end{array}$

$7392 \ldots$

5053

$46200 . \quad 46200$

1478 . $14: 8$

7392

7392

10857

10857

9396
1460

1460
9240

9240
9240

10857

0
9240
9240.

9240 .

0
17233

46200

46200

Low 5 No. 6 frel
9660
$8 \in 79$
8554

$8 \in 79$
8554
1835
6650

6650
59
1833

1833

1833

65.52

6552

2074

9396

9060
8501

8501
8732

8732
1873

1873
6789

70
1804

1804

1804

0
6457

6457
6457

64-6

$64 \div 6$
$2 \div 8$
0

0
$41<2$

$41<2$
0

0
7060

7466 . 746

$10857 \cdot 10857$

9060

8540

1864 .

6758
70

179

0

6427

6427

5637

4706

2107

0
4044
0

2906
0

0

9060

7076
1425

7224
1455

70

180

$180:$
$45200 \quad 46200$

$1478 \quad 1478$

7392
392

0

$108: 7$

$92<0$

9260

0
17233

(1)

00

$0857 \quad 10857$

$10857 \quad 10857$

0
9240

$\$ 240 \quad 9240$

$\begin{array}{rr}0 & 0 \\ 17233 & 17233^{\circ}\end{array}$

$45200 \quad 46200$

$7466 \quad 7466$

$10857 \quad 10857$

$9060 \quad 9060$

$\begin{array}{ll}8591 & 8294 \\ 8542 & 8939\end{array}$

$1853 \quad 1917$

6719.6950

$\begin{array}{rr}70 & 72 \\ 1785 & 1846\end{array}$

1785 1846

$6389 \quad 6610$

$5845 \quad 5511 \quad 5274$

$\begin{array}{rrr}0 & 1133 & 1306 \\ 0 & 4113 & 4277\end{array}$

$\begin{array}{rr}4113 & 4277 \\ 0 & 0\end{array}$

7078

$\begin{array}{ll}7078 & 6921 \\ 1513 & 1373\end{array}$ $\begin{array}{rr}0 & 0 \\ 6389 & 6610\end{array}$

0 


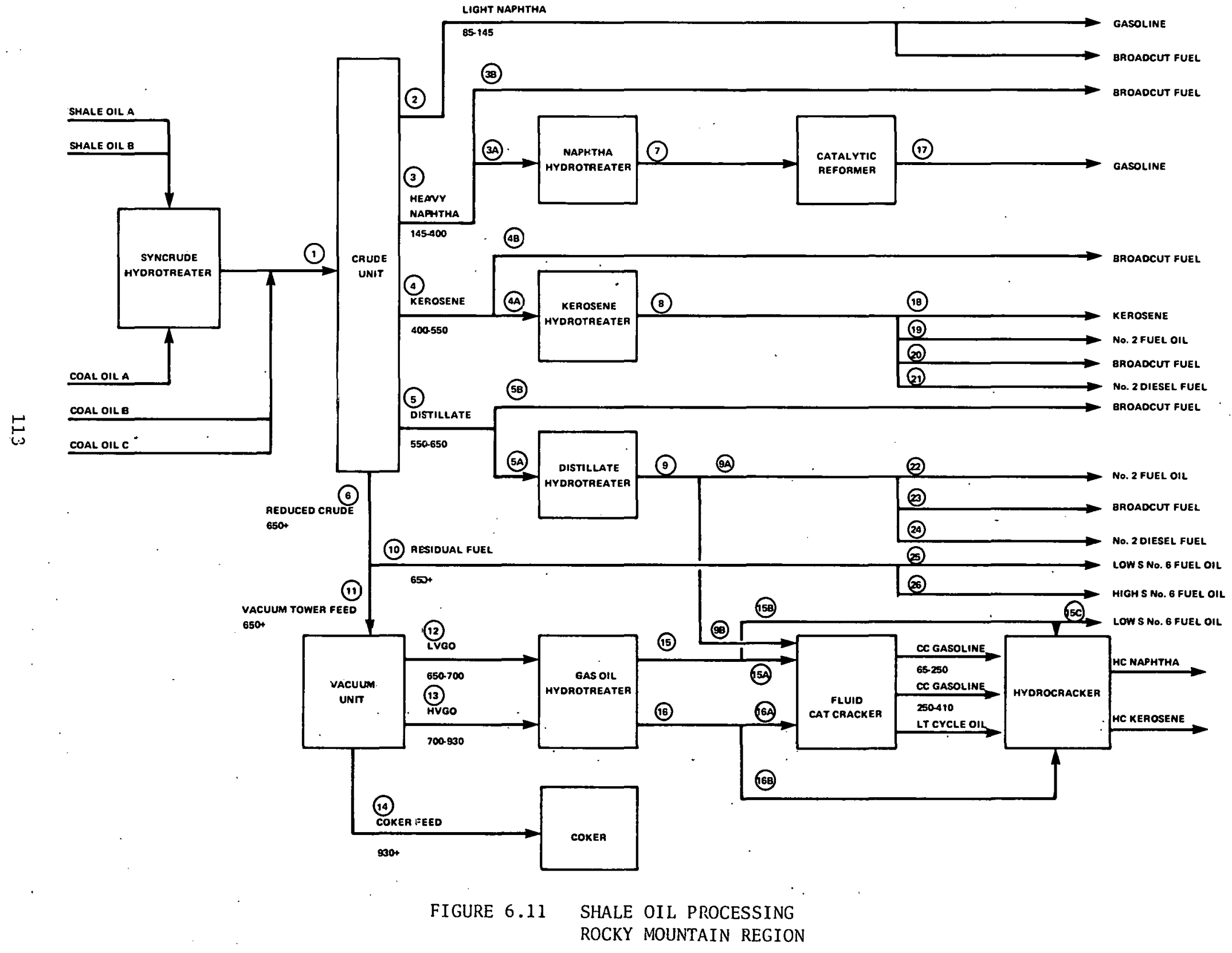


TABLE 6.29 COAL OIL PROCESIING ROCKY MDUNTAIN REGI:N

Stream

Number

Description

Coal Dil A to Hydrcoreater

Coal Of 1 B to Crude Dist.

Coal Oil C to Crude Dist.

TOTAL

$\begin{array}{ll}1 & \text { Crude Unit Charge } \\ 2 & \text { Light Naphtha }(85-1<5) \\ 3 & \text { Wide Boiling Naphth }(145-400) \\ 34 & \text { To Hydrotreater }\end{array}$

$3 \mathrm{~B}$

$4 \mathrm{~A}$

4B

5

$5 \mathrm{~A}$

$5 B$
6

7
Product Options

\begin{tabular}{|c|c|c|c|}
\hline $\begin{array}{l}\text { Case } 5 \mathrm{~A} \\
\text { Oanventional }\end{array}$ & $\begin{array}{c}5 \mathrm{~B} \\
\text { Conven: Ional }\end{array}$ & $\begin{array}{c}6 \\
\text { Max. Diesel } \\
\end{array}$ & $\begin{array}{c}7 \mathrm{~A} \\
\text { Broadcut }\end{array}$ \\
\hline 9600 & 9600 & 9600 & 9630 \\
\hline 9600 & 9600 & 9600 & 9630 \\
\hline 9600 & 9600 & 9600 & 9630 \\
\hline 28800 & 28800 & 28800 & 288100 \\
\hline 29760 & 29760 & 29760 & 29750 \\
\hline 854 & 854 & 854 & 354 \\
\hline 10042 & 10042 & 10042 & 10742 \\
\hline 10042 & 10042 & 10042 & 10342 \\
\hline 0 & 0 & 0 & 0 \\
\hline 8573 & 8573 & 8573 & $85 ; 3$ \\
\hline 8573 & 8573 & 8573 & $85 ; 3$ \\
\hline 0 & 0 & 0 & 0 \\
\hline 3557 & 3557 & 3557 & $35 \leq 7$ \\
\hline 3557 & 3557 & 3557 & 3331 \\
\hline 0 & 0 & 0 & $\approx 26$ \\
\hline 6734 & 6734 & 6148 & $6 ; 344$ \\
\hline 29760 & 29760 & 29760 & 29750 \\
\hline 10142 & 10142 & 10142 & 10142 \\
\hline 8573 & 8573 & 8573 & 8573 \\
\hline 3488 & 3488 & 3488 & 3266 \\
\hline 6734 & 6734 & 6148 & 6734 \\
\hline 6 & 6 & 586 & B \\
\hline 0 & 0 & 175 & 0 \\
\hline 3 & 3 & 218 & 3 \\
\hline 3 & 3 & 193 & 3 \\
\hline 0 & 0 & 175 & 0 \\
\hline 0 & 0 & 0 & 0 \\
\hline 0 & 0 & 169 & (1 \\
\hline 0 & 0 & 0 & c \\
\hline 3 & 3 & 207 & 3 \\
\hline 3 & 3 & 207 & 3 \\
\hline 0 & 0 & 0 & 0 \\
\hline 0 & 0 & 0 & 0 \\
\hline 7186 & 7600 & 8157 & 8573 \\
\hline 0 & 0 & 0 & 0 \\
\hline 1387 & 973 & 416 & 0 \\
\hline 0 & 0 & 0 & 0 \\
\hline 0 & 0 & 0 & 0 \\
\hline $\begin{array}{l}3488 \\
6693\end{array}$ & $\begin{array}{l}3488 \\
6693\end{array}$ & $\begin{array}{l}3488 \\
6148\end{array}$ & $\begin{array}{l}3266 \\
6693\end{array}$ \\
\hline 35 & 35 & 0 & 35 \\
\hline
\end{tabular}

Gasoline Supplements

\begin{tabular}{|c|c|c|c|}
\hline $\begin{array}{c}12 \\
\text { Methanol } \\
\end{array}$ & $\begin{array}{c}13 \\
\text { Ethanol }\end{array}$ & $\begin{array}{c}14 \\
\text { MTBE } \\
\end{array}$ & $\begin{array}{c}15 A \\
\text { Syn. Naphtha }\end{array}$ \\
\hline 9600 & 9600 & 9600 & 9600 \\
\hline 9600 & 9600 & 9600 & 9600 \\
\hline 9600 & 9600 & 9600 & 9600 \\
\hline 28800 & 28800 & 28800 & 28800 \\
\hline 29760 & 29760 & 29760 & 29760 \\
\hline 854 & 854 & 854 & 854 \\
\hline 10042 & 10042 & 10042 & 10042 \\
\hline 10042 & 10042 & 10042 & 10042 \\
\hline 0 & 0 & 0 & 0 \\
\hline 8573 & 8573 & 8573 & 8573 \\
\hline 8573 & 8573 & 8573 & 8573 \\
\hline 0 & 0 & 0 & 0 \\
\hline 3557 & 3557 & 3557 & 3557 \\
\hline 3557 & 3557 & 3557 & 3557 \\
\hline 0 & 0 & 0 & 0 \\
\hline 6734 & 6734 & 6734 & 6734 \\
\hline 29760 & 29760 & 29760 & 29760 \\
\hline 10142 & 10142 & 10142 & 10142 \\
\hline 8573 & 8573 & 8573 & 8573 \\
\hline 3488 & 3488 & 3488 & 3488 \\
\hline 6734 & 6734 & 6734 & 6734 \\
\hline 0 & 0 & 0 & 6 \\
\hline 0 & 0 & 0 & 0 \\
\hline 0 & 0 & 0 & 3 \\
\hline 0 & 0 & 0 & 3 \\
\hline 0 & 0 & 0 & 0 \\
\hline 0 & 0 & 0 & 0 \\
\hline 0 & 0 & 0 & 0 \\
\hline 0 & 0 & 0 & 0 \\
\hline 0 & 0 & 0 & 3 \\
\hline 0 & 0 & 0 & 3 \\
\hline 0 & 0 & 0 & 0 \\
\hline 0 & 0 & 0 & 0 \\
\hline 8573 & 8573 & 8573 & 8160 \\
\hline 0 & 0 & 0 & 0 \\
\hline 0 & 0 & 0 & 413 \\
\hline 966 & 1318 & 1683 & 0 \\
\hline 0 & 0 & 0 & 0 \\
\hline $\begin{array}{l}2522 \\
6693\end{array}$ & $\begin{array}{l}2170 \\
6693\end{array}$ & $\begin{array}{l}1805 \\
6693\end{array}$ & $\begin{array}{l}3488 \\
6693\end{array}$ \\
\hline 41 & 41 & 41 & 35 \\
\hline
\end{tabular}




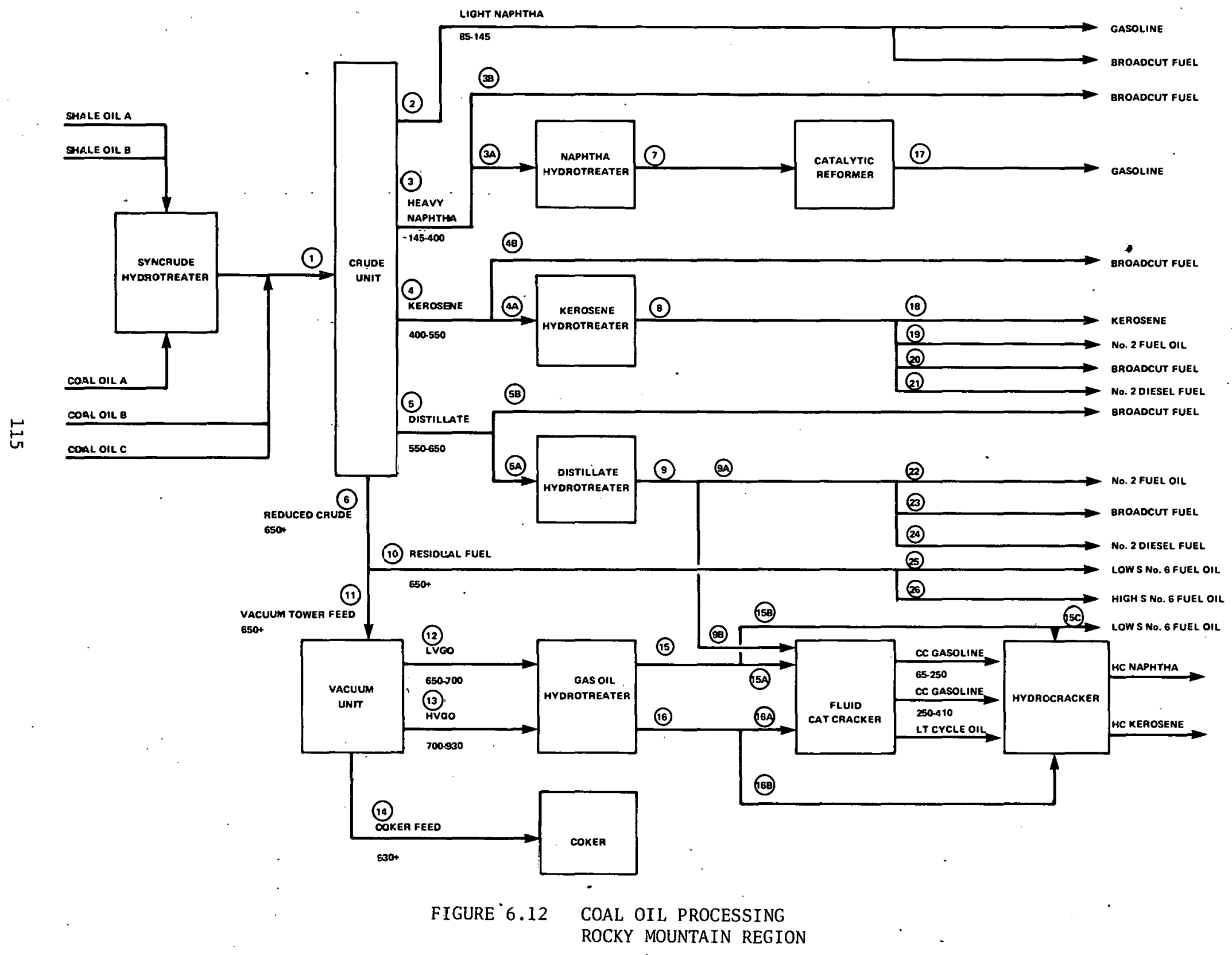


TABLE 6.30 SHAL VID- OONTINENT \& GREAT LAKES REGION

Stream

Number

escription

Shale 011

Shale 011 B

TOTAL TO HYDROTRRATER

Crude Unit Charge

Light Naphtha (85-145)

Wide Bolling Naptitha (145-400)

To Hydrotreater

To Broadcut Fcel

Kerosene (400-550)

To Hydrotreat $\equiv r$

To Broadcut Fise

Distillate $(5 \equiv 0-\epsilon 50)$

To Hydrotreater

To Broadcut Fue 1

Reduced Crude $(6 \leq 0+)$

TOTAL STREAMS $2-\epsilon$

Hydrotreated Raphtha

Hydrot reated terosene

Hydrotreated Distllate

Residual Fuel

Vacuum Tower Feed

Light Vacuum Gas Jil (E50-700)

Heavy Vacuum Gas Jil (700-930)

Coker Feed

Hydrot reated LJGO

To Fluid Cat Cracizer

To Hydrot reater

To Low S No. $\in$ Fuミ1 011

Hydrotreated HचGO

To Fluid Cat Czacker

To Hydrocracker

Kerosene to Jet Fnel

Kerosene to No. 2 Fuel J11

Kerosene to Broadeut

Kerosene to No. 2 Diese 1

Distillate to Mo. 2 Fuel of:

Distillate to froadcut

Distillate to Mo. 2 Diesel

Low S No. 6 Fuel roil

High S No. 6 Fiel 011
Mid-Continent, Product Options Case 2

Conventionel Max. Diesel Broadcut Fue1

Great Lakes, Product Options

24

Conventional Max. Diesel Broadcut Fuel

4690
4690
9380

10318
330
1651
1651
0
2425
2425
0
2064
2064
0
3848
10318

1667
2425
2023
0
3848
825
2992
31
795
795
0
0

.4690

4690

\section{4690}

4690
9380

\section{0}

$4840 \quad 48 \angle 0$

$4840 \quad 48 \angle 0$

$10318 \quad 10318 \quad 10318$

1651

330
1651

1651

10318
330

1651

1704

1651

2425

2425
2425

425
0

064

2064

3848

10318

0
2064

2064

0
3848

10318

2425

2425

0
2064

2064

0
3848

3848
10318

$1667 \quad 0$

2425

2425
2023

0
3848

2425

2023

0
3848

825
2992
31

31
795

795
795

0
0

10648

340

0
1704

0

2502

2502

2130

2130

0
3972

3972
10648

9680

9680

825
2992

31
795

795
0

0

2846

2846

2846

0
.2425
0

2846

0
2425
0

2846

2846

0
2425

0

0
0

0

2023

1116

0
0

$10648 \quad 10648$

$\begin{array}{rr}340 & 340 \\ 0 & 0\end{array}$

$17 C 4 \quad 1704$

1704
2502

$\begin{array}{ll}25 C 2 & 2502 \\ 25 C 2 & 2502\end{array}$

$\begin{array}{rr}0 & 0 \\ 2130 & 2130\end{array}$

$2130 \quad 2130$

$\begin{array}{rr}0 & 0 \\ 3972 & 3972\end{array}$

$10648 \quad 10648$

$1721 \quad 1721$

$2502 \quad 2502$

$2088 \quad 2089 \quad 2088$

$\begin{array}{rrr}0 & 0 & 0 \\ 3972 & 3972 & 3972\end{array}$

$\begin{array}{rrr}852 & 852 & 853 \\ 3088 & 3083 & 3088\end{array}$

$32 \quad 32 \quad 32$

$820 \quad 820 \quad 820$

$\begin{array}{rrrr}820 & 821 & \ddots & 820 \\ 0 & 0 & & 0 \\ 0 & 0 & & 0\end{array}$

2937

2937

0
2502
0

293?

$\begin{array}{rr}0 & 0 \\ 2502 & 2502\end{array}$

2502

502

250

0

2088

2023

0

2088

0

0

208

2088

0
0

ॠ 907 bbl to FCC via Streem 9B 


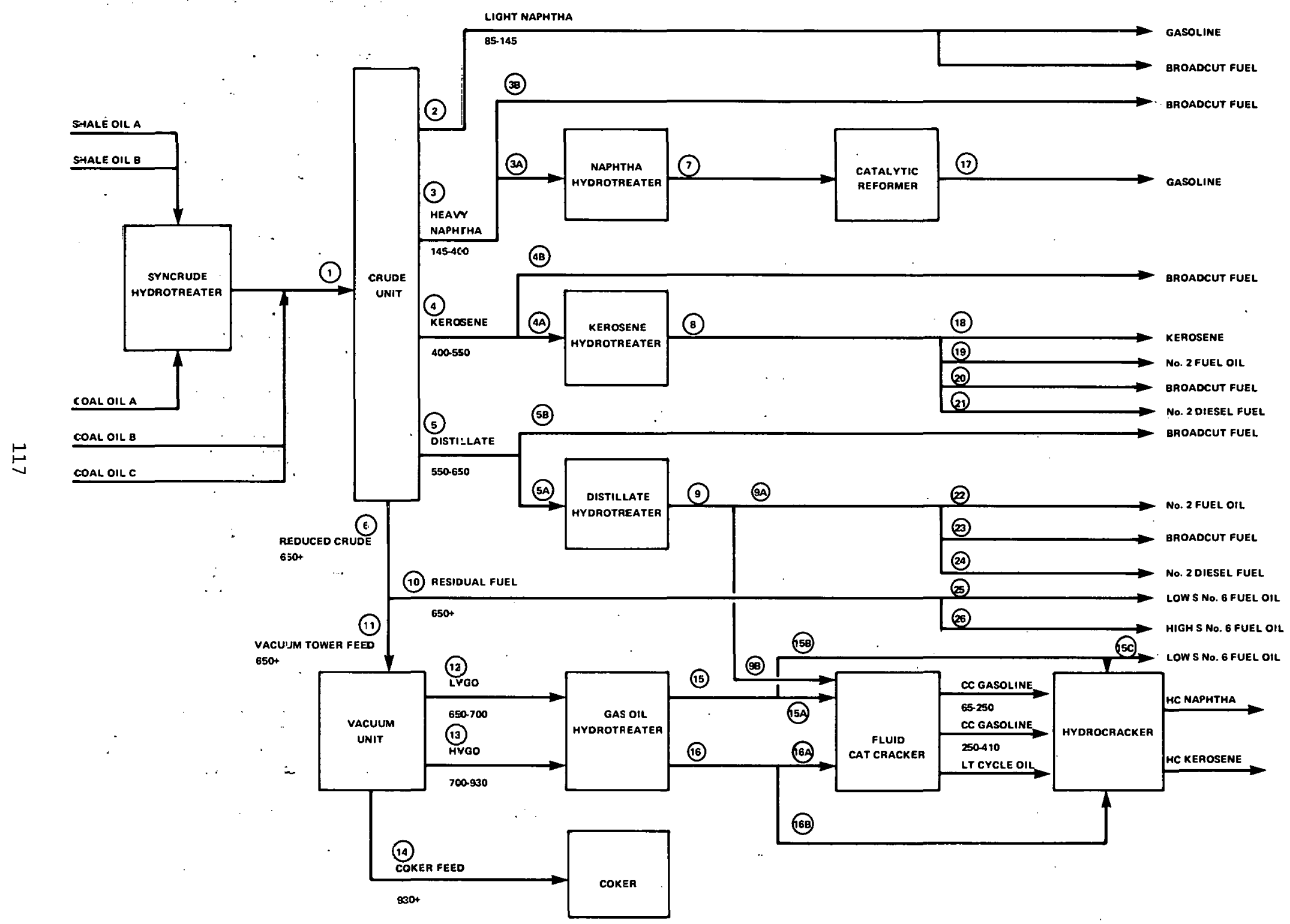

FIGURE 6.13 SHALE OIL PROCESSING

MID-CONTINENT \& GREAT LAKES REGIONS 
TABLE 6.3: COAL OIL PRICES:ing

MTD-CONTINEIT \& GREAT LAKES RECION

Stream

Number Description

Coal 011 a to Hycrocreaser Coal O11 i to Crude Dis:Coal oil $C$ to Crude Dis: TOTAL

Crude Unit Charge

Light Naphtha (85-145)

Wide Botlyng Naphtha (145-400)

To Hydrotreater

To Broadct t Fuel

Ko Hydrot reater

To Broatce

Distillate (550-650)

To Hydrotreater

To Broadcrt Fuel

Reduced Crude $(650+)$

TOTAL STREAMS $2-6$

\section{Hydrotreated Naphtha}

Hydrutreated Distillate

Residual Fuel

Vacuum Tower Feed

Light Vacuum Gas oil (65.1)-7(0)

Heavy Vacuum Gas 011 ( $7(11)-9 \Xi 0)$

Coker Feed

Hydrotreated LIGO

To Fluid Cat Cracke

To Hydrotreater

To Low S No. 6 Fuel 011

Hydrot reated HVGO

To Fluid Cat Cracker

To Hydrocracker

Kerosene to Jet Fuel

Kerosene to No. 2 Fuel $\mathrm{c}: 1$

Kerosene to Broadcut

Kerosene to No. 2 Diesel

Distillate to No. 2 Fuel oil

Distillate to Froadcut

Distillate to No. 2 Diesel

Low S No. 6 Fuel oil

High S No. 6"Fuel 011
$M=d-C o r t i n \in n t$, Product Options Conventional Max. Diesel Broadcut"Fuel

Great Lakes, Product Options

$\begin{array}{lll}5080 & 2080 & 2080 \\ 2080 & 2080 & 2080 \\ 2080 & 2080 & 2080 \\ .240 & 6240 & 6240\end{array}$

Conventional Max. Diesel Broxdcut Fuel

$\begin{array}{rr}6448 & 6448 \\ 184 & 194 \\ 2176 & 2176 \\ 2176 & 2176 \\ 0 & 0 \\ 1857 & 1857 \\ 1857 & 1857 \\ 0 & 0 \\ 771 & 771 \\ 771 & 771 \\ 0 & 0 \\ 1460 & 1460 \\ \epsilon 448 & 6448 \\ & \\ 2197 & 2197 \\ 1857 & 1857 \\ 756 & 756 \\ 1446 & 1446 \\ 14 & 14 \\ 14 & 14 \\ 0 & 0 \\ 0 & 0 \\ 13 & 0 \\ 0 & 13 \\ 13 & 0 \\ 0 & 13 \\ 0 & 0 \\ 0 & 0 \\ 0 & 0 \\ & 0\end{array}$

6448

2150

2150

2150 .

$2150-2150$

$6450 \quad 6450 \quad 6450$

6665

184
2176

2176

0
1857

1857
568

1289

771

0
1460

1460
.6448

2197

568

756
1446

14

14
0

0
13

0

13
0

0

150

1017

127
1285

591

756

$\begin{array}{rr}756 & 756 \\ 1.446 & 1445 \\ 0 & 0\end{array}$
6665
131
2142
2142
0
1926
1926
0
861
861
0
1655
6665
2154
1926
874
1591
14
14
0
0
13
0
7
6
0
0
0
0
$9: 0$
0
1026
0
0
844
1591
0

$6665 \quad 6665$

$\begin{array}{rr}131 & 131 \\ 2142 & 2142\end{array}$

$1926 \quad 1925$

$\begin{array}{rr}926 & 1925\end{array}$

$861 \quad 864$

$2164 \quad 216$

2164
1926

$844 \quad 17$

$14 \quad 1591$

$14 \quad 17$

$\begin{array}{ll}0 & 3\end{array}$

$13 \quad 13$

$\begin{array}{rr}0 & 13 \\ 0 & 3 \\ 0 & 3\end{array}$

0 .

$\begin{array}{rr}0 & 0 \\ 1624 & 0 \\ 0 & 0 \\ 302 & 0 \\ 0 & 0 \\ 0 & 0 \\ 344 & 0 \\ 1591 & 159: \\ 0 & 0\end{array}$
$142 \quad 2142$

$\begin{array}{rr}861 & 177 \\ 0 & 687\end{array}$

$1605 \quad 1605$ 


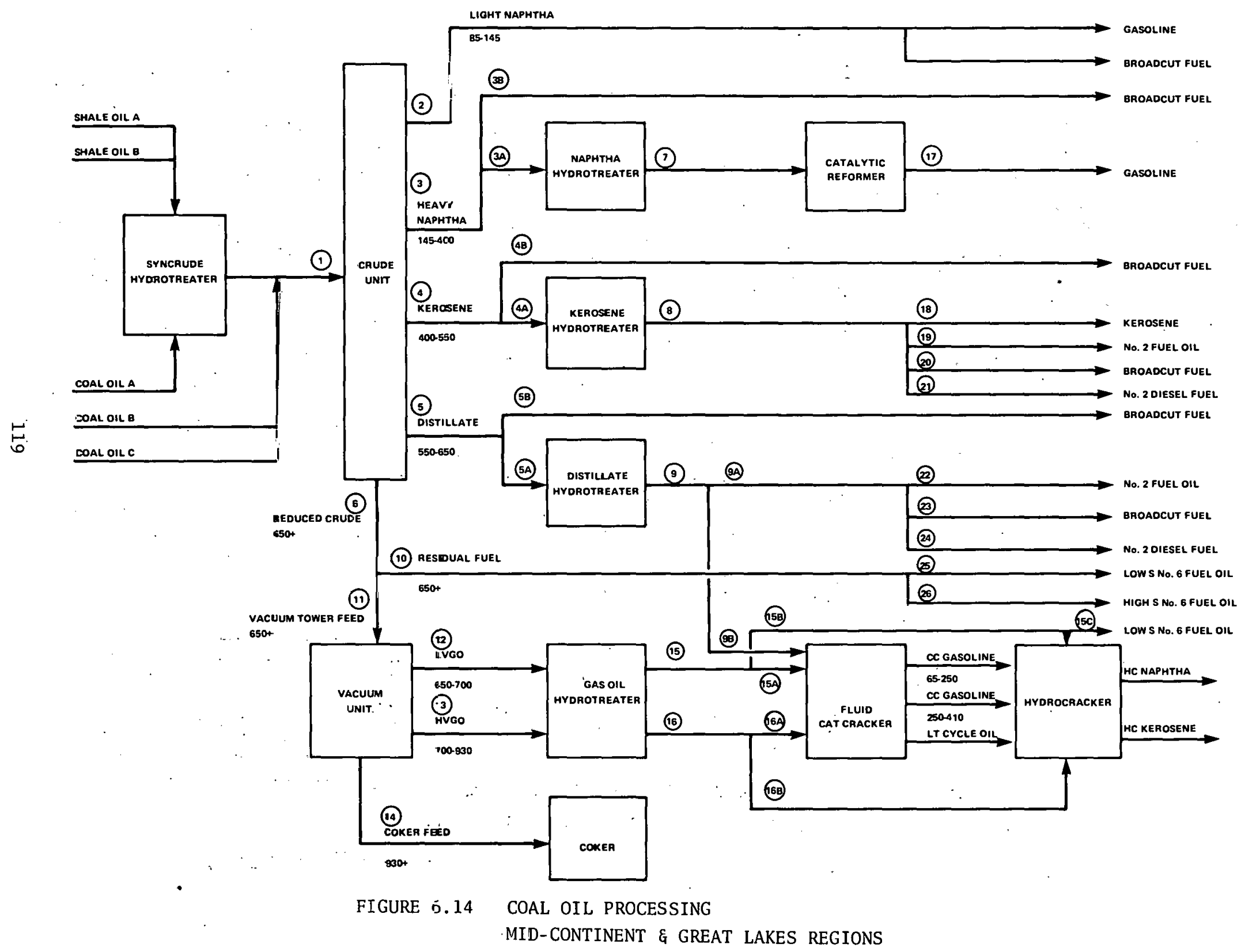




\section{G. Product Quality}

The product qualities for the four highway transportation fuels are shown in Tables 6.32 through 6.39 for all cases. The limiting gasoline octane specification in the regular and premium unleaded is the motor octane number: The binding distillation specifications are the maximum 35 percent off at $160^{\circ} \mathrm{F}$ and the maximum 96 percent of $f$ at $330^{\circ} \mathrm{F}$. The blends are at or near these specifications in nearly all cases.

Gasoline blends using methanol, ethanol or MTBE exceeded the Research octane specification by 0.6 to 4.9 numbers, while just meeting Motor octane because of the relatively high blending Research octanes of these components. A formula octane specification such as $(R+M) / 2$ would have reduced this research octane giveaway by about half, but would produce lower Motor octane blends with higher sensitivity.

The controlling qualities on the No. 2 diesel fuel are the maximum sulfur specification of $0.5 \mathrm{wt} \%$ and the minimum cetane blending number of 45.0 .

In the broadcut fuel blends the controlling specifications are the maximum Reid Vapor Pressure of 9.0 psi, the maximum sulfur of $0.25 \mathrm{wt} \%$, and the maximum nitrogen content of $200 \mathrm{ppm}$. The maximum nitrogen content spectfication is only active in the syncrude cases. Distillation curves were calculated for the broadcut fuel blends and are plotted in Figures 6.15 through 6.17 . 
TABLE 6.32 PRODUCT QUALITIES

SHAIE OIL CASES

ROCKY MOUNTAIN REGION

\begin{tabular}{ccc}
$\begin{array}{c}\text { Specification } \\
\text { Minimum }\end{array}$ & 1 & $\begin{array}{c}16 \\
\text { Maximum }\end{array}$ \\
\hline
\end{tabular}

REGULAR UNLEADED

Specific Gravity

Research ON Clear

Motor ON Clear

Reid Vapor Pressure

Pct of $三$ at $160^{\circ} \mathrm{F}$

Pct of at $210^{\circ} \mathrm{F}$

Pct of $E$ at $230^{\circ} \mathrm{F}$

Pct of $E$ at $330^{\circ} \mathrm{F}$

Pct Aromatics

Pct 01efins

Pct Supplement

PREMIUM UNLEADED

Specific Gravity

Research ON Clear

Motor DN Clear

Reid Vapor Pressure

Pct off at $160^{\circ} \mathrm{F}$

Pct of at $210^{\circ} \mathrm{F}$

Pct of $f$ at $230^{\circ} \mathrm{F}$

Pct of $f$ at $330^{\circ} \mathrm{F}$

Pct Aromatics

Pct Olefins

Pct Supplement

$\begin{array}{lrl} & & 0.756 \\ 90.5 & & 90.5 \\ 82.0 & & 82.0 \\ & 10.1 & 10.1 \\ 18.0 & 35.0 & 35.0 \\ 39.0 & 57.0 & 49.0 \\ 49.0 & & 59.3 \\ 84.0 & 96.0 & 94.3 \\ & 100.0 & 29.5 \\ & 100.0 & 7.3 \\ 10.0 & 10.0 & 0\end{array}$

0.767

93.3

82.0

10.1

35.0

51.7

61.2

96.0

34.2

20.6

0

0.753

93.5

84.0

18.0

39.0

49.0

84.0

10.0

0.769
93.5
84.0
10.1
35.0
49.4
58.5
94.5
41.0
8.3
0

26.9
21.4

100.0
10.0

0
$2 \mathrm{~A}$
Shale

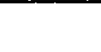

0.744
90.5
82.0
10.1
35.0
49.0
59.5
92.8
25.1
14.8
0

3

Maximum Diese1

$\quad 4$
Broadcut
Fuel

\subsection{5}

$\begin{array}{cc}0.769 & 0.755 \\ 92.5 & 90.5 \\ 82.0 & 82.0 \\ 10.1 & 10.1 \\ 35.0 & 35.0 \\ 50.1 & 51.5 \\ 59.9 & 60.7 \\ 96.0 & 94.7 \\ 34.7 & 30.6 \\ 14.1 & 12.5 \\ 0 & 0\end{array}$

$\begin{array}{cc}0.743 & 0.738 \\ 93.8 & 93.5 \\ 84.0 & 84.0 \\ 10.1 & 10.1 \\ 35.0 & 35.0 \\ 54.7 & 53.4 \\ 66.0 & 64.4 \\ 96.0 & 94.8 \\ 23.9 & 22.1 \\ 26.2 & 24.6 \\ 0 . & 0\end{array}$

0
Methanol

0.769
95.5
82.0
7.2
35.0
41.1
51.4
90.6
25.1
19.8
10.0

0.765
94.7
82.0
8.4
35.0
43.7
52.1
90.9
24.9
22.5
10.0

0.795

97.1.

84.0

6.4

35.0

43.0

55.4

96.0

96.0
37.3

3.6

10.0

0.774
96.4
84.0
10.1
35.0
45.1
54.7
94.9
29.2
13.0
10.0

10

MT BE

Syn Nap

\begin{tabular}{ll}
0.751 & \multicolumn{1}{c}{0.757} \\
92.3 & 90.5 \\
82.0 & 82.0 \\
10.1 & 10.1 \\
35.0 & 35.0 \\
53.1 & 47.2 \\
60.4 & 56.7 \\
93.4 & 92.5 \\
24.0 & 33.1 \\
16.2 & 7.1 \\
10.0 & 10.0
\end{tabular}

0.747

94.1

84.0

10.1

35.0

52.9

62.8

93.6

22.4
12.7

10.0

0.741
93.5
84.0
10.1
35.0
52.1
61.5
92.1
26.8
26.4
10.0


TABLE 6.33 PRODLCT CUALITIES

SHALE OLL CASES

ROCKY MOUNTAIN REGICN

\begin{tabular}{|c|c|c|c|c|c|c|c|c|c|c|}
\hline Spec & cation & 1 & $\begin{array}{c}15 \\
\text { 3roatcut }\end{array}$ & $\begin{array}{c}2 A \\
\text { Shale }\end{array}$ & $\begin{array}{c}3 \\
\text { Maximum }\end{array}$ & $\begin{array}{c}4 \\
\text { Broadcut }\end{array}$ & & & 10 & 11 \\
\hline Mininum & Meximum & Base Case & Fuel & 011 & Diesel & Fuel & Methanol & Ethanol & MT BE & Syn Nap \\
\hline
\end{tabular}

NO. 2 DIESEL

Specific Grayity

Flash Index (1)

Flash Point, ${ }^{\circ} \mathrm{F}$

Wt Pct Sulfur

Cetane Blending No;

Pour Point Index ${ }^{(2)}$

Pour Polnt, ${ }^{\circ} \mathrm{F}$

BROADCUT FUEL

Specific Gravity

Reid Vapor Pressure

Wt Pct Sulfur

Pet of at $400^{\circ} \mathrm{F}$

Nitrogen PPM

$\begin{array}{cc} & 378.2 \\ 125 & 0.500 \\ 45.0 & 640.5 \\ & 23 \\ & \\ & \\ & 9.0 \\ 5.0 & 0.25 .1 \\ 45 . C & 83.0 \\ & 200\end{array}$

\section{$0.840 \quad 0.842$}

378.2

125

378.2

125

$0.500 \quad 0.500$

45.0

385.7

45.0

413.6

4

0.843
67.0
200
0.500
45.0
235.6
-16

0.836

378.2

125

0.500

45.0

237.3

$-15$

0.839
378.2

125

0.500 、

45.0

247.1

$-14$

0.843
66.6

201

0.500

45.0

45.0
231.2

231.
-17

0.845
32.0

235

0.500

45.0

240.8

$-15$

0.843
66.0

201

0.500

45.0

232.9

$-16$

0.843

66.1 201

0.500

45.0

236.1

$-16$

0.736
9.0
0.250
88.0
0

0.762

9.0

0.250

71.6

200

$\overline{(1) \log _{10}(\text { FLASH INDEX) }}=42.1093-14.286 \log _{10}$ (FLASH POINT, $\left.{ }^{\circ} \mathrm{F}+460\right)$

(2) In (POUR POINT INDEX) $=-75.0883+12.5852$ In (POUR POIAT, $\left.{ }^{\circ} F+460\right)$ 
TABLE 6.34 PRODUCT QUALITIES

COAL OIL CASES

ROCKY MOUNTAIN REGION

Specification

MinLmum Maximum

REGULAR UNL ZADED

SFecific Gravity Research on Clear Mc.tor ON Clear

Reid Vapor Pressure

Pct of $f$ at $160^{\circ} \mathrm{F}$

Pct of $f$ at $210^{\circ} \mathrm{P}$

Pct of at $230^{\circ} \mathrm{F}$

Pet of $f$ at $330^{\circ} \mathrm{F}$

Pet Aromatics

Pet olefins

Pct Supplement

PREMIUM UNLEADED

Specific Gravity

Research ON Clear

Motor ON Clear

Reid Vapor Pressure

$P=t$ of $\bar{i}$ at $160^{\circ} \mathrm{F}$

$P=t$ of $f$ at $210^{\circ}$

Pat of $\mathrm{E}$ at $230^{\circ} \mathrm{F}$

Pct of $E$ at $330^{\circ}$

Pct Aromatics

Pct Olefins

Pct Supplement

$\begin{array}{rrr} & & 0.756 \\ 90.5 & & 90.5 \\ 82.0 & & 82.1 \\ & 10.1 & 10.1 \\ 18.0 & 35.0 & 35.1 \\ 39.0 & 57.0 & 49.1 \\ 49.0 & & 59.3 \\ 84.0 & 96.0 & 94.3 \\ & 100.0 & 29.5 \\ & 100.0 & 7.3 \\ 10.0 & 10.0 & 0 \\ & & \\ & & \\ & & 0.753 \\ 93.5 & & 93.5 \\ 84.0 & & 84.0 \\ & 10.1 & 10.1 \\ 18.0 & 35.0 & 35.0 \\ 39.0 & 57.0 & 52.9 \\ 49.0 & & 63.4 \\ 84.0 & 96.0 & 95.9 \\ & 100.0 & 28.4 \\ & 100.0 & 18.6 \\ 10.0 & 10.0 & 0 \\ & & \end{array}$

16

Broadcut

$5 \mathrm{~A}$

$\underline{\text { Coal 0il Coal 011 }} \begin{aligned} & \text { Maximum } \\ & \text { Diese1 }\end{aligned}$

0.767
93.3
82.0
10.1
35.0
51.7
61.2
96.0
34.2
20.6
0

0.764

90.5

82.0

10.1

48.4

48.4
58.2

94.6

34.3

5.5
0

0.759
90.5
82.0
10.1
35.0
48.1
58.6
94.2
30.6
5.7
0

0.787
93.8

93.8
82.0

6.1

26.9

43.7

54.6

96.0

39.4
14.7

14.7
0

0.750

0.750
93.5

84.0

0.749

93.5

35.0

52.6

63.4

96.0

26.9

21.4
0

0.759
93.5
84.0
10.1
35.0
51.9
62.1
96.0
33.2
17.0
0

0.788
96.8
84.0
10.1
25.0
41.2
52.2
96.0
43.5
7.8
0

0.766
92.3
82.0
10.1
35.0
52.0
61.1
96.0
34.9
16.8
0


0.752
93.8
84.0
10.1
31.6
50.2
62.2
96.0
28.1
15.8
0

0.771
94.6
82.0
7.0
35.0
42.1
53.0
92.5
24.7
14.0
10.0

0.780
93.0
82.0
6.0
35.0
46.4
55.6
95.2
29.9
7.3
10.0

$\begin{array}{ll}0.755 & 0.758 \\ 93.0 & 90.5 \\ 82.0 & 82.0 \\ 10.1 & 10.1 \\ 35.0 & 35.0 \\ 52.9 & 50.4 \\ 60.3 & 59.5 \\ 93.3 & 94.2 \\ 26.3 & 31.7 \\ 16.9 & 6.6 \\ 10.0 & 10.0\end{array}$

0.804
98.4
84.0
6.4
35.0
41.5
52.8
95.4
41.9
3.8
10.0

0.757
96.1
84.0
8.0
35.0
44.8
54.3
90.1
22.4
22.6
10.0

0.777
95.4
84.0
9.3
35.0
52.6
61.5
96.0
35.6
4.0
10.0

0.750

93.5

84.0

35.0

54.0

64.9

95.9

28.6

17.8

10.0 
TABLE 6.35 PRODUCT QUALITIES

COAL OIL CASES

ROCKY MOUNTAIN REGION

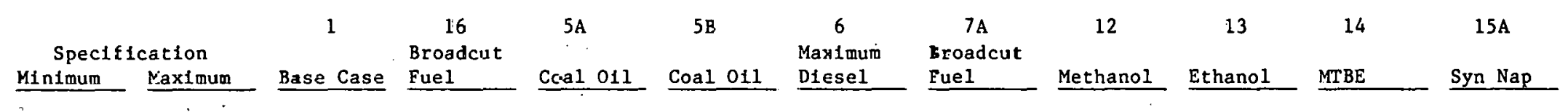

NO. 2 DIESEL

Specific Graydty
Flash Index

Flash Point, ${ }^{\circ} \mathrm{F}$

Wt Pct Sulfur

$\begin{array}{rccc} & & 0.840 & 0.842 \\ & 378.2 & 378.2 & 378.2 \\ 45 & & 1=5 & 125 \\ 45.0 & 0.500 & 0.500 & 0.500 \\ & & 45.0 & 45.3 \\ & 640.5 & 385.7 & 413.5 \\ & 20 & 2 & 4 \\ & & & \\ & & & 0.736 \\ 5.0 & 9.0 & & 9.0 \\ 45.0 & 0.250 & & 0.250 \\ & 88.0 & & 88.0 \\ & 200 & & 0\end{array}$

$\begin{array}{cc}0.837 & 0.836 \\ 37.3 .2 & 378.2 \\ 125 & 125 \\ 0.500 & 0.500 \\ 45.0 & 45.0 \\ 341.4 & 332.0 \\ -3 & -4\end{array}$

0.836
378.2
125
0.500
45.0
285.0
-9

0.834
$\vdots 78.2$
125
0.500

0.500

45.0

0.834

378.2

125

0.500

$328 \cdot 3$

45.0

0.833
378.2

378.2
125

0.832

378.2

125

Cetane Blending No;
Pour Point Index (2)

$-3$

272.7

0.500

45.0

0.500

0.835

Pour Point, ${ }^{\circ} \mathrm{F}$

BROADCUT FUEL

Spectfic Gravity

Reid Vapor Pressure

Wt Pct Sulfur

Pct of at $400^{\circ} \mathrm{F}$

200

$$
\begin{gathered}
0.770 \\
9.0 \\
0.250 \\
38.0 \\
200
\end{gathered}
$$

$\left.\overline{(1) \log _{10} \text { (FLASH INDEX) }}\right)=42.1093-14.286 \log _{10}$.FLASH POINT, ${ }^{\circ} \mathrm{F}+460$;

(2) In (POUR POINT INDEX) $=-73.0833+12.8852$ ln (DOUR POINT, ${ }^{\circ} \mathrm{F}+460$ ) 
TABLE 6.36

REGULAR UNEEADED

Specific Gravity

Research DN Clear

Mo =or ON Clear

Reid Vapor Pressure

Pct of at $160^{\circ} \mathrm{F}$

Pct of at $210^{\circ} \mathrm{F}$

Pct of at $230^{\circ} \mathrm{F}$

Pct of $f$ at $330^{\circ} \mathrm{F}$

Pct. Aromatics

Pct olefins

\section{PREMIUM LINLEADED}

Specific Gravity

Research. ON Clear

Motor ON Clear

Reid Vapor Pressure

Pct of $f$ at $160^{\circ} \mathrm{F}$

Pet of at $210^{\circ} \mathrm{F}$

Pct of at $230^{\circ} \mathrm{F}$

Pct of $f$ at $330^{\circ} \mathrm{F}$

Pct Aromatics

Pct Olefins
PRODUCT QUALITIES

SHALE \& COAL OIL CASES

MIDCONTINENT REGION

\begin{tabular}{|c|c|c|c|c|c|c|}
\hline \multirow{2}{*}{\multicolumn{2}{|c|}{ Specification }} & \multirow[t]{2}{*}{1} & \multirow{2}{*}{$\stackrel{5}{\text { Broadcut }}$} & 2 & \multirow{3}{*}{$\begin{array}{l}\quad 3 \\
\text { Maximum } \\
\text { Diesel }\end{array}$} & \multirow{3}{*}{$\begin{array}{l}\quad 4 \\
\text { Broadcut } \\
\text { Fuel }\end{array}$} \\
\hline & & & & & & \\
\hline Mininum & Maximum & Base Case & Fuel & Syncrude & & \\
\hline
\end{tabular}

0.755
91.7
83.0
10.1
35.0
45.4
56.5
92.4
33.6
11.5

0.751

83.0

10.1

18.0

39.0

35.0

57.0

49.0

96.0

100.0

100.0

11.5

0.763

94.5

85.0

10.1

30.3

48.4

60.2

96.0

33.7

13.6

0.764
92.1
83.0
10.1
30.4
42.0
53.6
92.8
35.2
7.4

0.761

92.5

83.0

10.1

34.6

49.1

60.5

96.0

32.4

5.5

0.762

94.7

85.0

10.1

33.8

51.6

62.4

96.0

35.4

19.1

18.2
91.5

83.0

0.756

91.8

83.0

10.1

33.4

46.7

58.2

94.0

31.4

10.6

0.764

94.5

85.0

10.1

28.5

46.1

58.2

95.2

$\begin{array}{ll}96.0 & 96.0 \\ 33.3 & 33.5\end{array}$

$14.9 \quad 18.2$

33.9

$\begin{array}{ll}100.0 & 33.7 \\ 100.0 & 13.6\end{array}$


TABLE 6.37

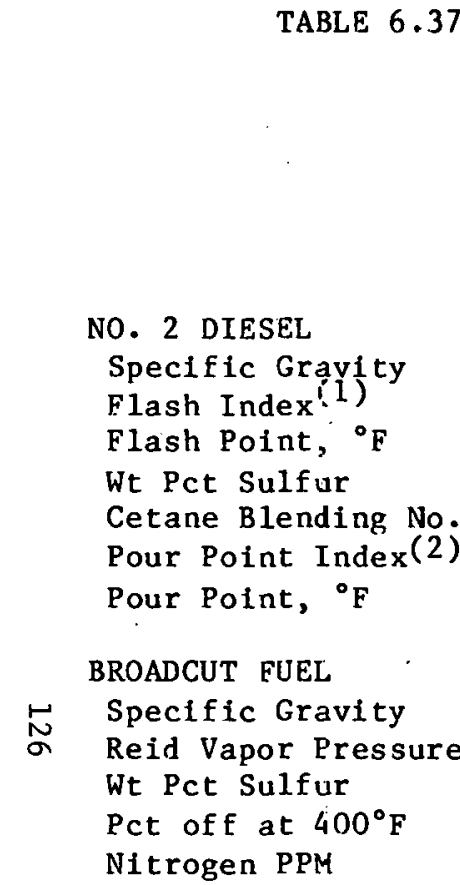

PRODUCT CUALITIES

SHALE \& COAL OIL CASES

MIDCONTINEHT REGION

Specification
Min:mum Max

45.0

0.500
640.5
20

$\begin{array}{cc}5.0 & 9.0 \\ 45.0 & 0.250 \\ & 88.0 \\ & 200\end{array}$

5

Broadcut

Fue1

3ase Case

0.841
378.2
$\therefore 25$
0.472
45.0
465.6
8
0.838
378.2
125
0.455
45.5
459.5
8

\subsection{7 \\ 9.0 \\ 0.250 \\ 58.0}

0
4

Broadcut

Fue1

Maximum

Diese1

0.839
378.2
125
0.261
45.0
331.7
-4

0.824

378.2

125

0.206

45.0

290.6

$-9$

$$
\begin{aligned}
& 0.818 \\
& 9.0 \\
& 0.250 \\
& 45.0
\end{aligned}
$$$$
200
$$

$\overline{(1) \log _{10} \text { (FLASH INDEX) }}=42.1093-1<.286 \log _{10}$ (FAASE FOINT, ${ }^{\circ} \mathrm{F}+460$ )

(2) $1 \mathrm{n}$ (POUR POINT INDEX) $=-73.5883+12.8852$ In (POUR FOINT, ${ }^{\circ} \mathrm{F}+460$ ) 
TABLE 6.38

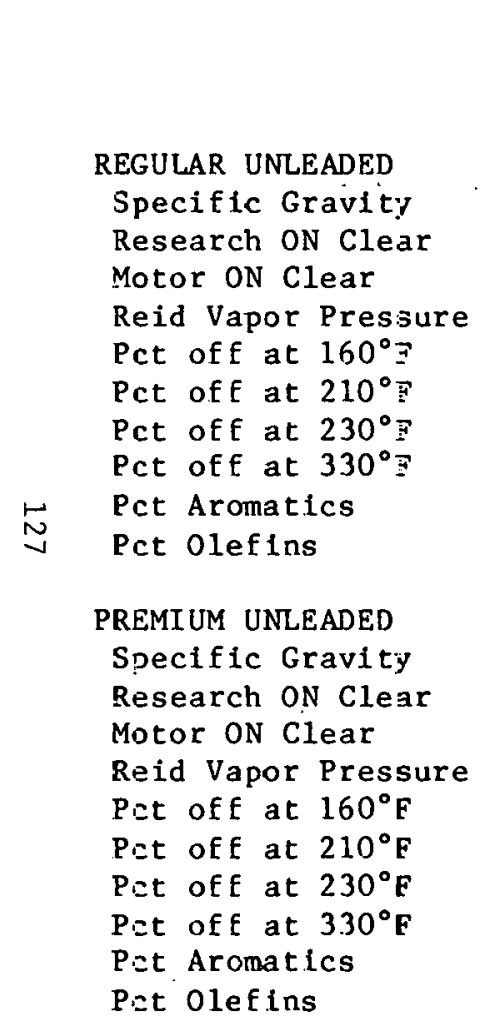

PRODUCT QUALITIES

SHALE \& COAL OIL CASES

GREAT LAKES REGION

\begin{tabular}{|c|c|c|c|c|c|c|}
\hline \multicolumn{2}{|c|}{ Specification } & 1 & \multirow{2}{*}{$\begin{array}{l}\quad 5 \\
\text { Broadcut } \\
\text { Fuel }\end{array}$} & 0 & \multirow{2}{*}{ 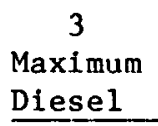 } & \multirow{2}{*}{$\begin{array}{l}\quad 4 \\
\text { Broadcut } \\
\text { Fuel }\end{array}$} \\
\hline Minimum & Maximum & Base Case & & Syncrude & & \\
\hline & & 0.752 & 0.737 & 0.756 & 0.761 & 0.738 \\
\hline $\begin{array}{l}92.0 \\
83.5\end{array}$ & & $\begin{array}{l}92.2 \\
83.5\end{array}$ & $\begin{array}{l}92.0 \\
83.5\end{array}$ & $\begin{array}{l}92.2 \\
83.5\end{array}$ & $\begin{array}{l}92.5 \\
83.5\end{array}$ & $\begin{array}{l}92.0 \\
83.5\end{array}$ \\
\hline & 10.1 & 10.1 & 10.1 & 10.1 & 10.1 & 10.1 \\
\hline 18.0 & 35.0 & 34.3 & 32.6 & 33.6 & 35.0 & 35.0 \\
\hline 39.0 & 57.0 & 46.2 & 50.8 & 45.0 & 50.9 & 54.7 \\
\hline $\begin{array}{l}49.0 \\
84.0\end{array}$ & 96.0 & $\begin{array}{l}57.2 \\
92.7\end{array}$ & $\begin{array}{l}62.3 \\
94.0\end{array}$ & $\begin{array}{l}56.4 \\
93.1\end{array}$ & $\begin{array}{l}61.6 \\
96.0\end{array}$ & $\begin{array}{l}65.7 \\
96.0\end{array}$ \\
\hline & 100.0 & 32.5 & 22.4 & 34.0 & 32.1 & 21.8 \\
\hline & 100.0 & 12.9 & 23.0 & 7.1 & 9.9 & 20.9 \\
\hline & & 0.763 & 0.770 & 0.753 & 0.758 & 0.765 \\
\hline $\begin{array}{l}95.0 \\
85.5\end{array}$ & & $\begin{array}{l}95.0 \\
85.5\end{array}$ & $\begin{array}{l}95.0 \\
85.5\end{array}$ & $\begin{array}{l}95.0 \\
85.5\end{array}$ & $\begin{array}{l}95.8 . \\
85.5\end{array}$ & $\begin{array}{l}95.0 \\
85.5\end{array}$ \\
\hline & 10.1 & 10.1 & 10.1 & 10.1 & 10.1 & 10.1 \\
\hline 18.0 & 35.0 & 35.0 & 29.0 & 35.0 & 35.0 & 29.2 \\
\hline 39.0 & 57.0 & 49.9 & 45.2 & 51.5 & 52.5 & 46.7 \\
\hline 49.0 & & 61.6 & 57.2 & 62.2 & 62.8 & 158.6 \\
\hline 84.0 & $\begin{array}{r}96.0 \\
100.0\end{array}$ & $\begin{array}{l}95.9 \\
38.4\end{array}$ & $\begin{array}{l}96.0 \\
36.8\end{array}$ & $\begin{array}{l}94.8 \\
35.8\end{array}$ & $\begin{array}{l}96.0 \\
33.5\end{array}$ & $\begin{array}{l}96.0 \\
33.4\end{array}$ \\
\hline & 100.0 & 9.9 & 0.5 & 22.8 & 26.8 & 3.6 \\
\hline
\end{tabular}




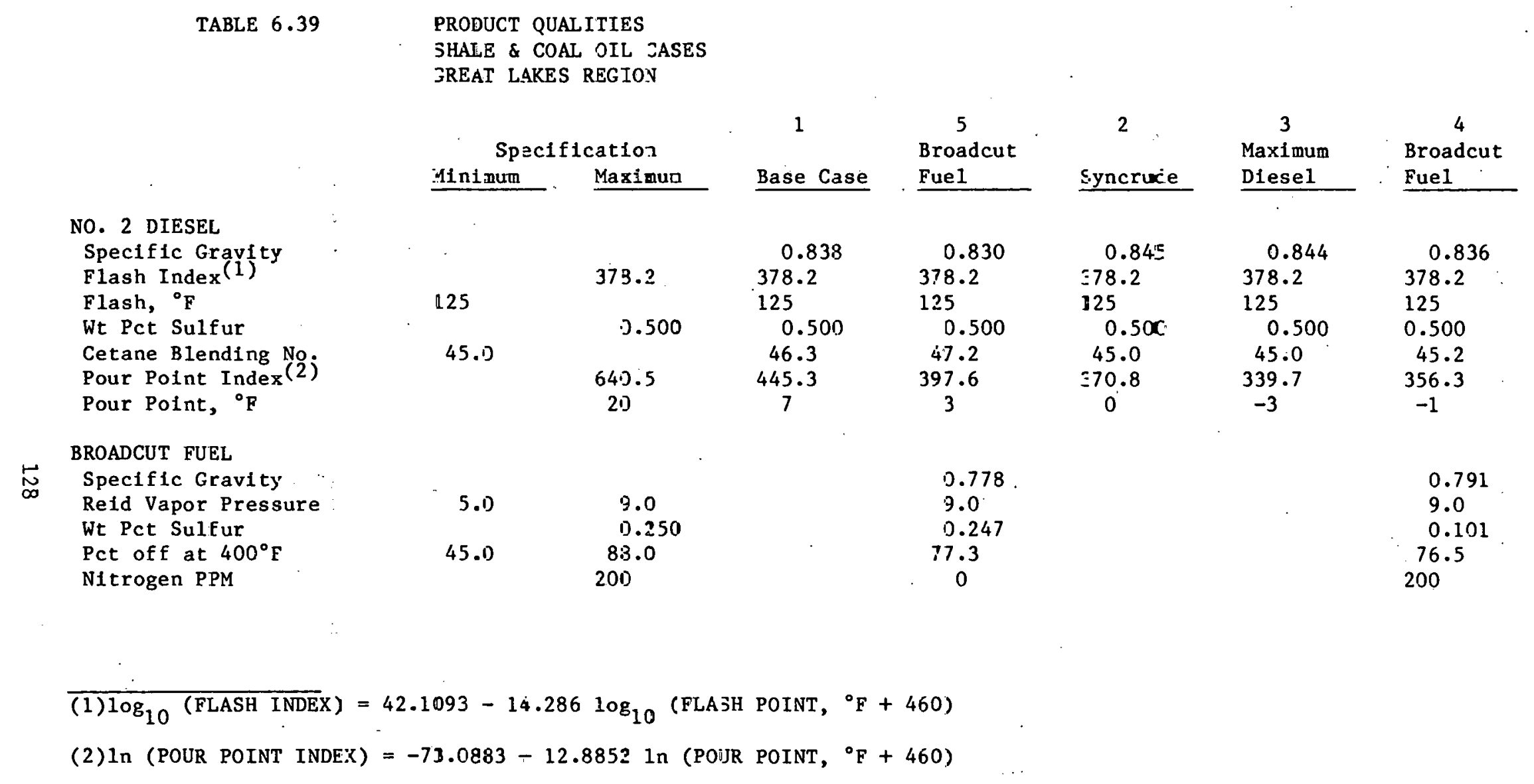




\section{FIE 6.15 BROADCUT FUEL DISTILLATIOHS}

ROCKY MOUNTAIN FEEIOLN

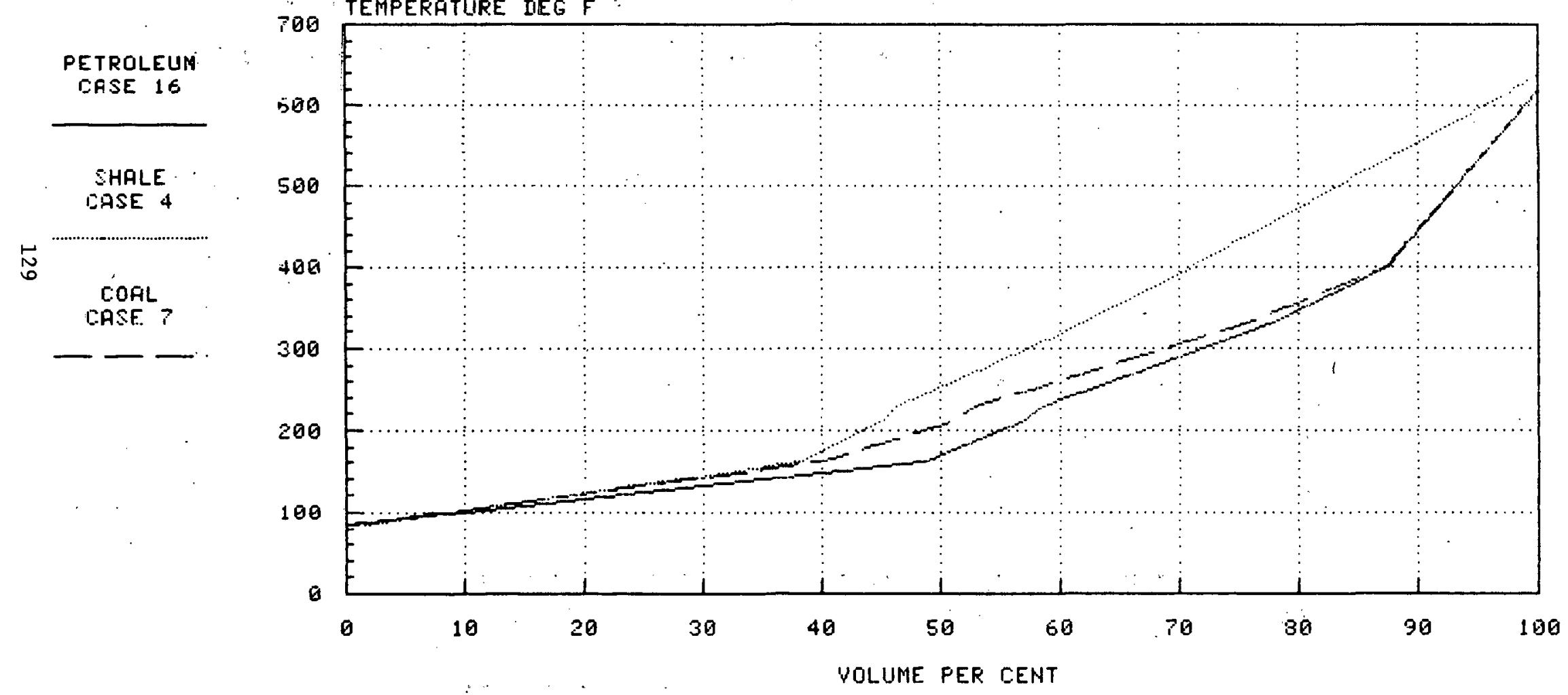




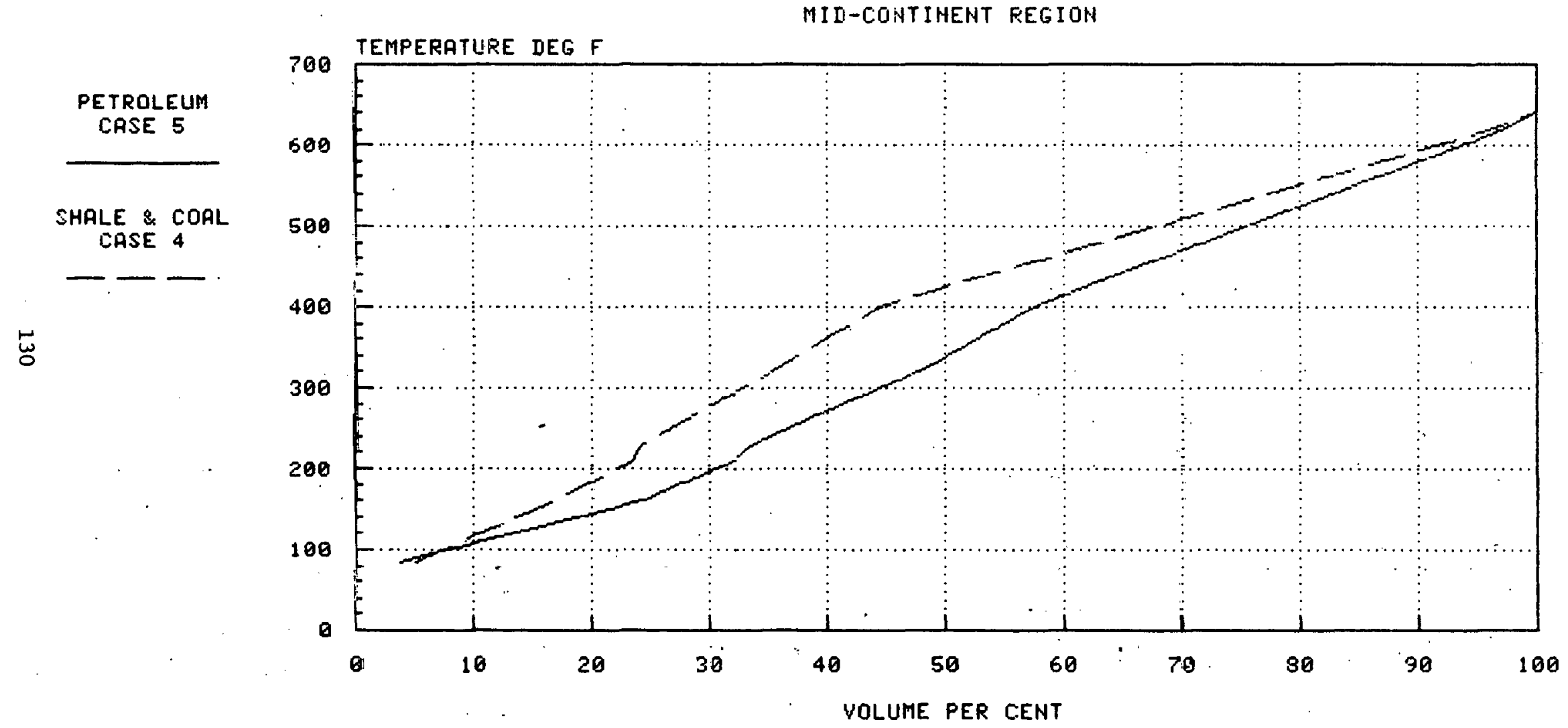




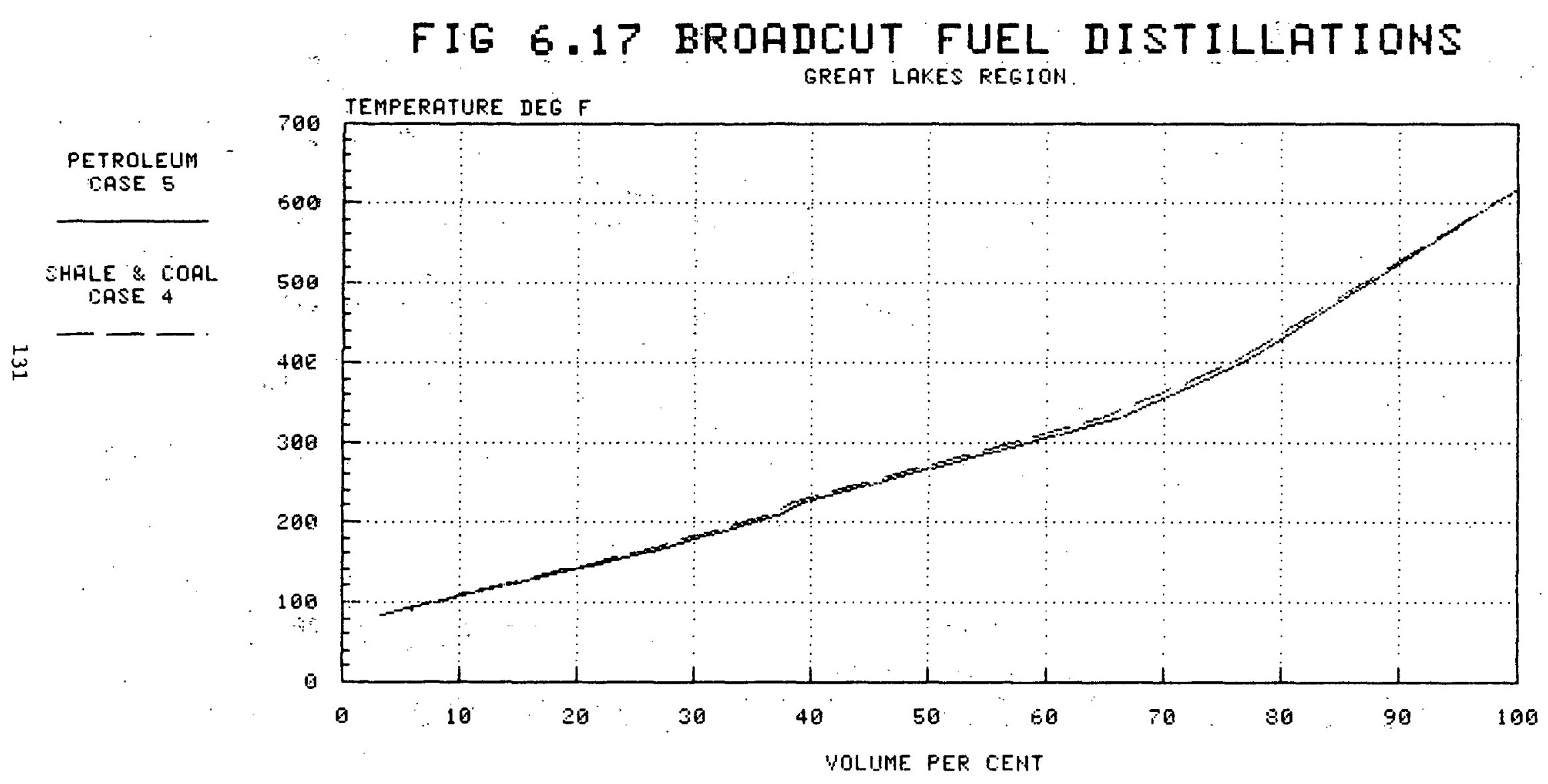




\section{CONCLUSIONS}

Fuels production models were developed to represent composite regional refineries using forecasts of 1995 crude supply and product slates. Within the constraints established and a likely processing scheme, the computer runs optimized the refinery operation and blending to make specification products.

When shale- and coal-derived crudes were included as feedstocks, the models demonstrated how these materlals probably: would be processed. Identity of the synthetic constituents was maintained as internal feedstocks through processing to finished components for product blends.

The results provide a logical, validated basis for blending test fuels for physical evaluation in following phases of the project. Compositions from the various cases will be used as patterns for blending transportation fuels with petroleum and synthetic components.

Comparisons are made in the following paragraphs of the major effects of processing shale and coal oils in the framework of the study.

\section{A. Raw Materials}

The representative synthetic crudes. used in this study can replace petroleum raw materials on about one-to-one ratio. In the Rocky Mountain region, a barrel of coal oil replaced 1.03 barrels of petroleum. Shale ofl replaced 0.95 barrels. In the other two regions, the syncrudes processed together replaced 0.97 and 1.02 barrels of petroleum.

Production of incremental diesel. fuel conscrved law macerlals when replacing $30 \%$ of the gasoline. Part of the benefil was a reduction in product quantity because of better fuel economy for diese1, and part was less processing than needed for gasoline.

Broadcut fuel also achieved savings in raw materials when replacing 40\% of the gasoline. Broadcut fuel economy is intermediate between gasoline and diesel fuel, so product savings were smaller. On the other hand, processing requirements for broadcut fuel were substantially reduced by using naphtha without reforming. The net effect on a per barrel basis was comparable to incremental diesel fuel. However, broadcut fuel could: supply a greater proportion of the transportation needs while diesel tuel was near its limt in the maximum diesel cases.

Use of gasoline supplements had varying:effects on petroleum uoc. Methanol replacud 0.83 to 0.96 barrel of petroleum and displaced nearly all butane from the gasoline blends. Ethanol replaced 0.96 to 1.21 barrel of raw materials while MTBE replaced aicomparable 1.16. to 1.21 barrel. Methanol for synthetic naphtha was less effective, replacing 0.56 barrel of raw material for each barrel of methanol feed; the ratio would increase to 1.35 if based on the volume of synthetic naphtha produced from methanol. 
Using $34 \%$ shale oil in raw materials resulted in an increase of about $19 \%$ in processing energy, or about 0.7 volume percent of total raw materials. Coal o11 at $23 \%$ of refinery feedstocks caused a $2 \%$ increase in energy used or about 0.1 volume percent on crude. Shale ofl was higher because more shale oil was processed and it received more processing.

Processing energy effects were less in the Mid-Continent and Great Lakes regions, where combined synthetic crudes were $29 \%$ and $16 \%$ of feedstocks, respectively. Total energy increased 11.6 and $3.4 \%$, amounting to 0.7 and 0.3 volume percent of raw materials.

Maximum diesel fuel production reduced energy consumption 0.2 and 0.6 volume percent of raw materlals except in the Rocky Mountain coal liquids case where it increased by 0.9 volume percent of raw materials because of high total distillate production in the base case.

Broadcut fuel manufacture saved processing energy equivalent to 0.8 to 1.4 volume percent of raw materlals when processing synthetic crudes. Similar savings of 0.7 to 1.0 volume percent occurred when making broadcut fuel with petroleum crudes.

Gasoline supplements were used at 10 percent concentration in blends and saved varying amounts of energy expressed as percent of raw materials:

Energy Savings, Volume \%

Shale Cases $\quad$ Coal Cases

$\begin{array}{lll}\text { Methanol } & 0.2 & 0 \\ \text { Ethanol } & 0.6 & 0.3 \\ \text { MTBE } & 0.8 & 0.3 \\ \text { Synthetic Naphtha } & 0.4 & 0\end{array}$

Energy effects in processing for the variables studied are significant and worthy of consideration in planning. They are small compared to the raw materials effects and the quantities are included in the figures for total raw materials discussed above.

\section{Investment Cost}

Capital costs for additional facilities to process synthetic crudes w111 be substantial. Shale ofl may need more facilities than coal liquids because of the greater amount of processing.

The effect of maximum diesel fuel production apparently depends on the particular lefinery oftuation. Investment costs increased in the Rocky Mountain region but decreased in the other two regions.

Broadcut fuel reduced investment cost in all cases evaluated by reducing amount of downstream procesing. This advantage will be avallable only if a new fuel and engine combination is developed before the facilities aie built to produce conventional specification fuels. This same conclusion would apply to other types of fuels with mintmal processing or to conventional fuels with revised specifications. 


\section{Compositions and Product Quality}

Gasolines shows Research octane giveaway (octane higher than specified minimum) with methanol, ethanol and MTBE. In this respect the blends are similar to gasohol although the Motor octane, vapor pressure and distillation were controlled. Unlike gasohol, however, use of alcohols as blending components applies their higher octanes to best advantage and allows benefits from adjusting other operations, such as lower catalytic reforming octanes.

Research octane giveaway also occurred in some of the maximum diesel and broadcut fuel. cases because gasoline volumes were reduced, leaving a surplus of high octane components.

Wide boiling naphtha from coal oil is a desirable reformer feed and is somewhat better than the average quality naphtha from shale oll. However, when broadcut fuel is made, naphtha from elther shale or coal was selectively used in that product to avoid hydrotreating and reforming steps and their costs. Distillate fractions from shale oil were desirable in diegel fuel because of their high cetane number. 
VIII. FUTURE WORK

\section{A. Application of Results}

Conclusions from the fuels optimization studies in the preceding section provide the foundation for work in subsequent tasks. Blend formulations will be selected from the case studies for three major products--gasoline, diesel fuel, and broadcut fuel. Selectlons will be based on consideration of :

- Range of synfuel component volumes

- Variation in combinations with other components

- Variation in calculated physical properties

- Availability of components.

Fuels will be blended with selected formulations in quantities needed for testing at Southwest Research Institute and at other laboratories involved in similar evaluations.

Fuel compositions from other studies, if available and different from those developed in this project, may be included in evaluations.

The testing schedule will be planned in detatl for the fuels selected. The main effort will be directed toward performance evaluations in engines avallable for each type of fuel. If adequate quantities of fuel can be obtained, durability tests will be run. In addition, laboratory evaluations will be made of fuel stability and materials compatibility of selected fuels.

\section{B. Fuels Formulation}

Blends will be prepared using components trom varlous prucessing steps to closely approximate specific product composition and qualities. Petroleum components are generally available and can be obtained as representative streams for use as needed.

Synfuels components, however, have limited avallability, particularly those from hydrotreating and processing steps downstream of pre-treatment and distillation. The following tables outline the components and currently known status on availability: 


\section{GASOLINE COMPONENTS}

\section{Petroleum}

Shale

Coal

Light Naphtha $85-145^{\circ} \mathrm{F}$

'Reformate 90 RON

$\mathrm{X}$

100 RON

$\mathrm{x}$

$x$

CAT Gasoline $\mathrm{C}_{5}-250^{\circ} \mathrm{F} \quad \mathrm{X}$

$\mathrm{x}$

Alkylate $250-410^{\circ} \mathrm{F}$

Natural Gasoline 12 1b

Butane

Methanol

Ethanol

MTBE

Synthetic Naphtha

0

0

0

0

0

0

DIESEL FUEL COMPONENTS

Petroleum

Shale

Coal

Kerosene* $400-550^{\circ} \mathrm{F}$.

Distillate* $550-650^{\circ} \mathrm{F}$

Light Cycle 011*

$\mathrm{X}$

$\mathrm{x}$

$\mathrm{X}$

Hydrocracker Kerosene

$\mathrm{X}$

$\mathrm{X}$

$\mathrm{x}$

0

0

BROADCUT FUEL COMPONENTS

Petroleum Shale Coal

Light Naphtha $85-145^{\circ} \mathrm{F}$

Heavy Naphtha $145-400^{\circ} \mathrm{F}$

Kerosene* $400=550^{\circ} \mathrm{F}$

Distillate* $550-650^{\circ} \mathrm{F}$

Light Cycle Oil*

Butane

$x$

$x$

$X$

$x$

$\mathrm{X}$

$\mathrm{X}$

$\because$

$\bar{X}=$ avallable $0=$ not avallable

$\star=$ Treated

. 
Gasoline blends can be blended to octane and RVP targets by pre-calculation and adjusting the proportions of two octane levels of reformate and of butane.

Synfuel stocks currently on hand include naphtha, kerosene (JP-5) and diesel fuel from Paraho shale oil processed at SOHIO's Toledo Refinery. Also avallable are middle distillate and full range distillate from SRCII coal liquefaction at Pittsburg and Midway Coal Mining Company's pilot plant in DuPont, Washington; these latter two fuels are high in aromatics content and should be upgraded by addition of hydrogen for use in conventional engines.

The nonavallability of certain blend stocks indicated above may limit the number of fuels for testing. However, three major coal liquefaction pilot plants are scheduled for startup in 1980; coal liquids from these plants may be converted into products for use in engines. Also, an Air Force project to produce maximum jet fuel from syncrudes may generate by-products of other fuels.

C. Fuels Evaluations

A detailed schedule of engine testing and other laboratory evaluations will be prepared for fuels that can be produced from avallable components.

Fuels produced in other programs will also be accepted for evaluation. For example, gasoline and diesel fuel produced from coal by Sasol Limited in South Africa would be a welcome addition to the study.

Data from the fuels evaluations will be summarized and interpreted for potential modifications to the original optimization studies.

D. Computer studies

With refinery models avallable for all three regions, modiffcations to incorporate new information will be the basis of revised optimization studies. Modifications may include:

- Feedback from engine and laboratory evaluations of fuels. described above.

- Revised product specifications, for example, to meet modified engine requirements or to evaluate a range of gasoline octane levels or diesel fuel cetane specifications.

- New or up-dated syncrude quality data or downstream processing schemes from ongoing process research.

- New technology to upgrade synfuel components by other process techniques. 


\section{E. Recommendations for Other Research}

Many synfuels studies, including this one, have been directed toward making fuels to meet current specifications. This requirement introduces extensive and expensive processing of syncrudes to upgrade to conventional petroleum quality levels. An alternative would be to provide lower severity . processing to intermediate quality levels that would be used in engines modified to accept the lower quality fuels.

An organized approach would outline a range of cetane numbers, hydrogen contents, nitrogen contents, or other parameters for evaluation. Many of the quality parameters are interrelated and cannot be varied independently. However, treating severity changes would result in simflar degrees of changes for various measures of quality.

This planning would need to consider spectfic feedstocks. For instance, a shale oil may be hydrotreated to a nitrogen level that assures stable products. This amount of hydrogen addition causes other changes in sulfur. content, bolling range, aromatics content and other qualities related to hydrogen content. The diesel fuel fraction from this degree of treatment is likely to have a cetane number and other properties to make excellent quality diesel fuel although its lubricity may be low from the hydrotreating.

A coal ofl syncrude may have less nitrogen and more aromatic molecules than shale oil. Thus hydrogenation to a comparable nitrogen level would change other properties but leave higher levels of aromatics. The diesel fraction would still be aromatic and have a low cetane number. Therefore, coal ofl could be treated to additional intermediate levels, producing a diesel fraction of intermediate cetane numbers.

Brodalcul fuel variacions could tollow simflar severity studies. Gasoline by nature is a high severity product, mainly because of the need for complete sulfur and nitrogen removal from naphtha to protect reformer catalysts. However, a case could be developed for lower severity pretreatment of syncrude with high severity treating only of naphthas to roforming. 
APPENDIX 


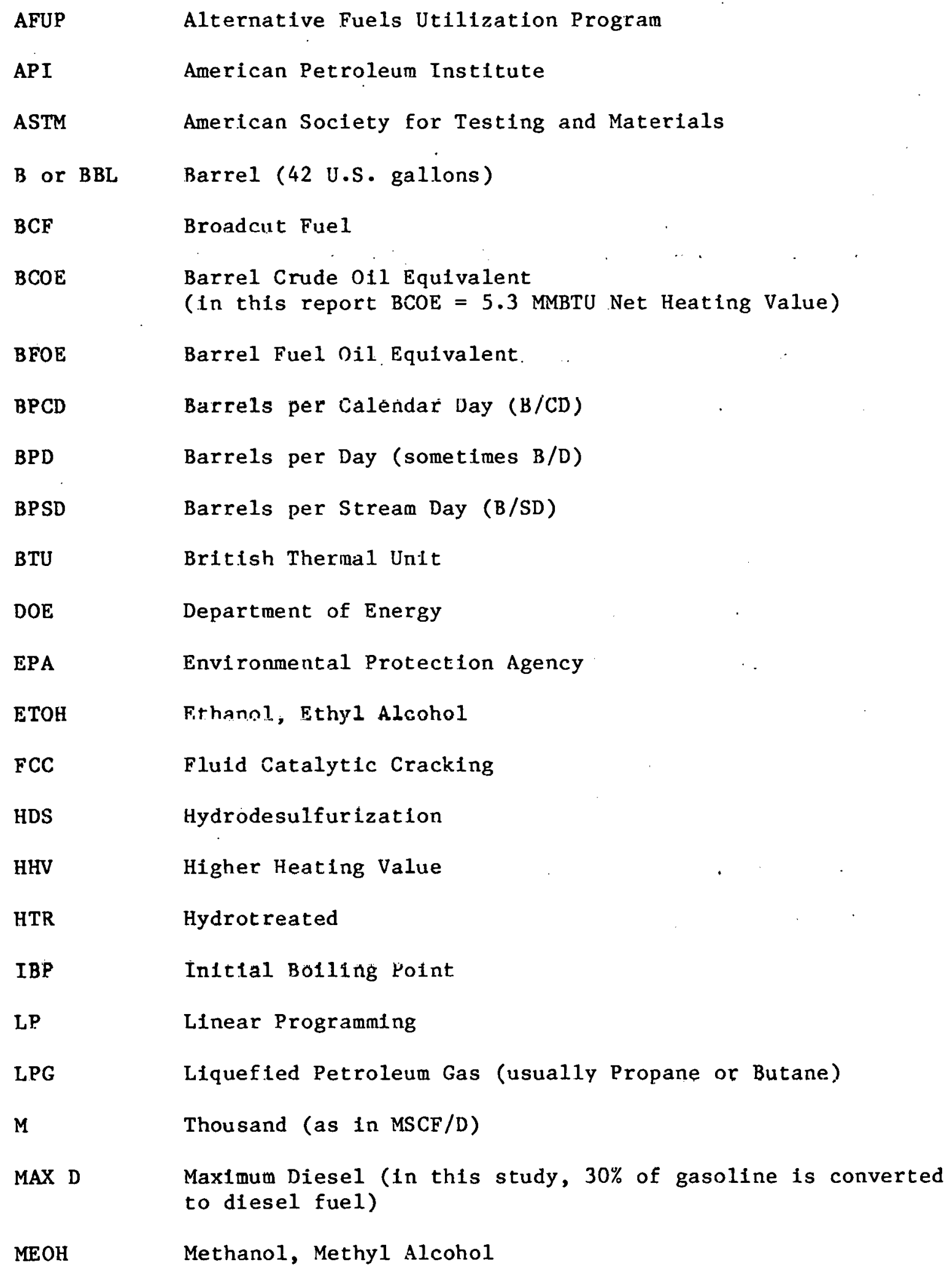




\begin{tabular}{|c|c|}
\hline MM & Mililon (as in MMBTU/D) \\
\hline MON & Motor Octane Number \\
\hline MPG & Miles per Gallon \\
\hline MTBE & Methyl-Tertiary-Buty1 Ether \\
\hline $\mathrm{PAD}$ & Petroleum Administration for Defense \\
\hline PADD & PAD District \\
\hline $\mathrm{R}+\mathrm{M} / 2$ & Average of Research and Motor Octane Numbers \\
\hline RON & Research Octane Number \\
\hline RPMS & Refinery and Petrochemical Modeling System \\
\hline RVP & Reid Vapor Pressure \\
\hline $\mathrm{SAE}$ & Society of Automotive Engineers \\
\hline $\mathrm{SCF}$ & Standard Cubic Feet \\
\hline SR & Straight Run \\
\hline SynNaph & Synthetic Naphtha Made From Methanol \\
\hline TAME & Tertiary Amyl Methyl Ether \\
\hline TBA & Tertiary Butyl Alcohol \\
\hline VGO & $\begin{array}{l}\text { Vacuum Gas OIl } \\
(\text { LVGO = Light VGO) } \\
(\text { HVGO = Heavy VGO })\end{array}$ \\
\hline VLI & Vapor Lock Index \\
\hline VMT & Velulele Miles Traveled \\
\hline
\end{tabular}


Alkylation

Catalytic Cracking

Catalytic Reforming

Coking

Hydrocracking

K Factor

Sour Crude

Sweet Crude
Chemical reaction to add an alkyl group to another compound. In petroleum refining, typically reacting an olefin with an iso-paraffin, e.g., butylene with isobutane to make a gasoline component.

A process to convert high bolling gas oil fractions into lighter materials such as gasoline and distillate by high temperature and catalyst. It is widely used and can make about $40 \%$ of the gasoline production from a refinery.

A process to rafse octane ratings of gasoline stocks by converting naphthenes and paraffins to aromatice; with hydrogen as a major byptoduct. Severity can be controlled to produce the desired product octane.

Thermal cracking (pyrolysis) process to convert heavy ofls to gasoline and distillate plus gas ofl for cat cracking, using high temperature and long residence time. Product coke 16 a low ash, high BTU solid.

Cracking at high hydrogen pressure to suppress coke formation on the catalyst. Converts heavy stocks to lighter products and may saturatc aromatic rings as well. as nlefins.

Watson (or UOP) characterlzarion factor used to correlate with many physical and chemical properties. Mathematically, $\mathrm{K}$ is the cube root of the average bolling point in degrees Rankine divided by specific gravity at $60^{\circ} \mathrm{F}$. High values $(12.5-13.0)$ indicate high paraffin content. Low values $(10.5-11.0)$ Indicate high aromalics.

Originally Indicated presence of dissolved $\mathrm{H}_{2} \mathrm{~S}$ in crude which smelled "sour". Now generally means high sulfur content, over 0.5 wt $\%$. Lor.a 1 Custom may vary and $0.5 \%$ - 1.0 wt\% be called intermediate and over $1.0 \mathrm{wt} \%$ labeled sour.

Originally indicated absence of dissolved II 3 aud 1 ts odor. Now generally means low sulfur content, $0.5 \%$ or less. 
Swing Crude

Vacuum Distillation

Visbreaking
A crude type which is allowed to vary or "swing" as opposed to other relatively constant "base" crudes. It is usually marginal in some respect, such as high cost or not required for some special product, so that it could be displaced by a new crude.

A separation process used on high bolling fractions. Under low pressure, boiling points of these fractions are reduced so distillation can be done without thermal decomposition.

A thermal cracking (pyrolysis) process to convert heavy oils. Short residence time is used to prevent coke formation. Yield of light products is lower than coking. Unconverted heavy ofl is usually lower viscosity than the feed. 


\section{United States}

Department of Energy

Washington, D.C. 20585

THRD-CLASS MAIL

POSTAGE \& FEES PAID

U.S. DEPT. OF ENERGY

PERMIT NO. G 20

THIRD CLASS MAIL

Official Business

Penalty for Private Use, $\$ 300$ 